\title{
Agama Monarki Israel
}

Dr. Marthin Steven Lumingkewas, M.Div 


\section{Bab I}

\section{Problematika Allah Israel}

Studi ilah-ilah Kanaan dalam hubungannya dengan Yahweh menjadi semakin terbuka dengan ditemukannya teks-teks kuno - khususnya dari kota kuno Ugarit pada tahun 1929 - yang juga disebut Ras Shamra - berlokasi di Siria modern. Melalui inskripsinskripsi yang ditemukan ini, para ahli Dunia Timur Tengah Kuno umumnya sepakat agama Israel 'lebih dekat kepada agama Kanaan daripada yang digambarkan Perjanjian Lama.' Dipercaya bahwa agama Israel secara langsung mendapat pengaruh, berbagi elemen atau secara natural berasal dan mengalami perkembangan dari kultus Kanaan. ${ }^{1}$ Dalam banyak hal, agama Israel terlihat paralel dengan agama-agama bangsa sekitarnya; terutama multi ilah yang dimilikinya - bahkan multi Yahweh. Pernyataan ini semakin jelas ketika ada publikasi yang membedakan antara agama populer - sistem agama

1 Para sarjana ANET terbagi dalam tiga kelompok besar perihal hubungan agama Israel dengan agama Kanaan. Kelompok pertama percaya bahwa agama Israel mendapat pengaruh dari berbagai elemen kultus Kanaan. Bagi kelompok ini, agama Israel pada mulanya berbeda dengan agama Kanaan, namun karena proses asimilasi yang terjadi di Kanaan, agama Israel pada akhirnya memiliki warna agama Kanaan - selanjutnya mendapat label sinkretik oleh penganut Yahwistik etis. Kelompok kedua, berpandangan agama Israel dalam bagian tertentu berbeda dengan agama Kanaan sekaligus bisa diidentikkan - berdasarkan sharing kultur dan perkembangan yang terjadi antara kedua sistem agama tersebut semenjak akhir Jaman Perunggu sampai Jaman Besi Akhir; bahkan sampai era Persia. Kelompok terakhir yakin Israel dalam naturnya berasal dari Kanaan - Israel secara umum memiliki karakter Kanaan. Latar belakang kultur Israel serupa dengan Kanaan, sehingga dunia religious di antara mereka tidak berbedangan sekaligus pemisahan ideologi, ilah dan kultus pada akhir monarki. 
natural-tribal yang dianut masyarakat Israel, dilawankan dengan agama resmi kerajaan yang berlandaskan aturan etis-hukum kerajaan. Perbedaan tersebut membuka pintu bagi kesadaran adanya kontradiksi kepercayaan dan praktiknya dalam satu negara dan dalam satu periode yang sama - di mana terdapat banyak tingkatan ekspresi agama yang dinyatakan dalam praktiknya. Klaim hanya satu jenis agama hadir di Israel menjadi tidak mungkin. Israel digambarkan memiliki beragam jenis kepercayaan - sekaligus bentuk praktik agama tersebut. yang selalu berubah dan berkembang seiring berjalannya waktu - bukan gambaran kompetisi antara dua agama - agama Kanaan versus agama Israel seperti tergambar dalam kitab Ibrani. ${ }^{2}$

Agama Kanaan memiliki sistem Panteon dengan El sebagai Allah sesembahan utama, yang dalam Perjanjian Lama sering dihubungkan dengan Yahweh pada periode Levant ${ }^{3}$ kuno. Para sarjana ANET (Ancient Near Eastern Text), ${ }^{4}$ berbeda pendapat perihal fungsi, peran dan perkembangan $\mathrm{El}$ dan Yahweh di area Levant pada Milenium Kedua SM. Ada kelompok sarjana ANET seperti Wellhausen dan Heisser yang percaya El dan Yahweh ilah identik. Sedangkan sarjana lain seperti Mark S. Smith dan Lowell K. Handy, melihat El dan Yahweh sebagai ilah berbeda sejak semula kemudian berbagi karakter, namun tetap tidak pernah berfusi atau

${ }^{2}$ Richard S. Hess, Israelite Religion: An Archaeology and Biblical Survey (Grand Rapids Michigan: Baker Academy Press, 2007), 66, lihat juga Fransesca Stavrakoipoulou dan John Barton, 2010, Religious Diversity in Ancient Israel and Judah (Britain: T \& T Clark), 37- 60 yang khusus membahas agama populer versus agama kerajaan di Israel dan Yehuda.

${ }^{3}$ Ruang lingkup area Levant terbentang dari laut Tengah di Barat, Gurun Pasir Arab di Selatan dan Mesopotamia di Timur. Penulis menggunakan terminologi Levant dalam tulisan ini untuk memudahkan memetakan gabungan tiga wilayah tersebut.

${ }^{4}$ ANET (ancient Near Eastern Texts) $=$ Teks Timur Tengah Kuno. Istilah ini selanjutnya akan terus dipergunakan penulis dalam bentuk ANET saja. 
merger sampai dikemudian hari Yahweh dinyatakan sebagai Allah tunggal.

Penulis Perjanjian Lama menggunakan terminologi El untuk menunjuk pada Yahweh Allah Israel dan El allah Kanaan. Gambaran ini tentu saja menimbulkan banyak perdebatan tentang sosok El; apakah El Kanaan ini identik dengan El Allah Patriak atau keduanya berbeda? Jika dihubungkan dengan Yahweh, pertanyaanya adalah: apakah Yahweh merupakan Allah terpisah dengan El atau keduanya Allah identik? Jika identik - maka dengan cara apa dan bagaimana Yahweh dan El identik? Sebaliknya, apabila El dan Yahweh tidak identik, bagaimana menjelaskannya?

Narasi Musa yang dimulai dari Keluaran pasal 3, berisi catatan mengenai Allah Yahweh yang menyatakan dirinya kepada Musa dalam semak terbakar dan mengklaim dirinya sebagai satusatunya Allah yang juga disembah oleh para patriak. Menurut versi ini, agama Yahwistik merupakan agama para Patriak (yang juga diasumsikan dalam teks Kejadian 12-50). Sehingga disimpulkan agama Israel telah dimulai dengan perintah Yahweh kepada Abraham ketika keluar dari Ur dengan meninggalkan allah yang ia sembah sebelumnya.

Namun gambaran ini bergeser ketika melihat sumber Priest dalam Keluaran pasal 6. Di sini nama Yahweh dikatakan pertama kali dinyatakan kepada Musa; kepada para Patriakh, Yahweh menyatakan dirinya dengan nama El-Shaddai (Kel. 6:2, Kej.17:1). Teks-teks ini menunjukkan agama para Patriak dengan El sebagai Allahnya telah 'mendahului' sebelum mengalami pergantian atau kepenuhannya dalam agama Yahwistik Israel. Teks-teks berikut bahkan memperlihatkan perbedaan antara agama para Patriak dengan agama Musa lebih jelas lagi. Keluaran 6:3: "Aku menampakkan diriku kepada Abraham, Ishak dan Yakub sebagai El Shaddai, tetapi dengan namaku Yahweh aku tidak menyatakan kepada mereka”. Yosua 24:14, '...jauhkanlah Allah yang dilayani nenek moyangmu di 
seberang sungai Efrat dan di Mesir, dan layanilah Yahweh. Kedua teks ini jelas tidak mendeskripsikan keserupaan El dengan Yahweh.

Beberapa ahli ANET, seperti Mark S. Smith dan Rainer Albertz yakin masyarakat Levant berangsur-angsur menggabungkan ilah Kanaan El dengan ilah Israel Yahweh menjadi satu Allah yang disebut Yahweh - penggabungan terjadi melalui proses perkembangan panjang sampai era akhir monarki. Sarjana lain seperti Patrick D. Miller mengklaim ada perbedaan tajam antara kedua ilah tersebut - di mana mereka tidak pernah berfusi. Sedangkan Michael S. Heisser yakin kedua ilah tersebut identik sejak awal, oleh karena itu tidak perlu dibedakan. Identifikasi 'El' Allah Kanaan dengan 'El' Allah Patriak, semakin mempersulit identifikasi Yahweh menurut Heisser.

Menurut Mark S. Smith, istilah Israel memiliki arti 'umat yang diperintah El.' Dipergunakannya istilah Israel dan bukan IsraYahweh atau Isra-Yah untuk menyebut Israel pada dasarnya telah mencuatkan pemikiran bahwa Allah mula-mula Israel adalah El dan bukan Yahweh. ${ }^{5}$ Namun, istilah-istilah ini sangat ambigu ketika harus menunjuk pada Allah Israel semata, mengingat nama El umum dipergunakan untuk menunjuk pada kepala Panteon masyarakat Semit Barat. Bagi Wenham, El merupakan nama dari kepala Panteon Semit Barat yang umum dipergunakan pada periode Milenium Kedua SM sekaligus tidak pernah ada bukti penggunaan nama 'Yahweh' dalam catatan ekstra-biblikal pada periode ini. ${ }^{6}$ Nama 'Yahweh' ditemukan umumnya dalam narasi frame-work dari teks Kejadian daripada dalam dalam teks-teks dialog. Editor Yahwist kelihatannya bermaksud mengidentifikasi Allah Musa dengan Allah Patriak dengan menambahkan frasa 'Yahweh' pada kompaun El, seperti El Elyon,

5 Mark S. Smith, The Origin of Biblical Monotheism: Israel's Polytheistic Background and the Ugaritic Text (New York: Oxford University Press, 2001), 143

${ }^{6}$ Gordon J. Wenham, The Religion of the Patriarchs, (Leicester:IVP, 1980), 181 
menjadi Yahweh El Elyon (Kej. 14:22) atau 'Adonai Yahweh' (15:2). ${ }^{7}$ Dalam narasi Patriak, istilah El ini merupakan epitet umum yang dipakai untuk menunjukkan Allah Israel; seperti El Elohe-Israel. Penggunaan istilah El disini jelas menunjuk pada Allah Kanaan El, yang dapat dihubungkan penggunaannya pada suku-suku awal Israel di mana mereka menyembah El dan bukan Yahweh. Pada poin ini menurut Smith, El masih dipandang sebagai kepala Panteon sedangkan Yahweh dan Ba'al berada pada kondisi berebut kekuasaan pada level mereka (level 2) dalam Panteon Kanaan - namun dengan berjalannya waktu, Yahweh pada akhirnya mampu menjadi kepala Panteon menggantikan bapanya El. ${ }^{8}$

Penyataan diri Yahweh kepada Musa yang mengidentifikasikan dirinya sebagai Allah para Patriak dengan menghubungkan epitet El kepada Yahweh dalam Keluaran 6:2-3: "Aku adalah Tuhan (Yahweh). Aku Menampakkan diri kepada Abraham, Kepada Ishak dan kepada Yakub, sebagai Allah (El Shadday), namun dengan namuku Tuhan (Yahweh) aku belum menyatakan diriku kepada mereka.” Menurut Douglas J. Baker, teks ini merupakan bentuk penyataan di mana para Patriak belum mengerti akan nama Yahweh. Namun, mereka sudah mengetahui siapa sesungguhnya Yahweh - hanya saja mereka belum memiliki pengalaman perjumpaan seperti yang dimiliki Israel melalui Musa. Bagi Baker, Allah tidak mungkin bergerak dalam cara yang tidak diketahui dalam sejarah, apalagi dengan mengajukan nama baru yang kemudian menimbulkan dikotomi antara keduanya? Tentu sulit dipahami. Nama baru benar-benar telah diberikan kepada Musa dan Israel dan pada saat bersamaan telah ada 'pengetahuan' akan Allah

\footnotetext{
${ }^{7}$ Ibid., 182

${ }^{8}$ Ibid., Smith, The Origin Of Biblical, 144
} 
dalam konsep teologis yang juga harus diapresiasi. Ini bukan skenario 'yang mana/atau' melainkan 'ke duanya/dan'.

Smith menolak pandangan Baker di atas. Bagi Smith, teks tersebut memperlihatkan bahwa Yahweh tidak diketahui oleh para Patriak. Sebagai penyembah El, narasi Patriakal tidak pernah membedakan antara El dan Yahweh, namun editor terkemudian memasukkan nama Yahweh ke dalam narasi patriakal, padahal para Patriak tidak pernah mengenal El sebagai Yahweh. ${ }^{10}$ El adalah Allah para Patriak - El yang sama yang disembah oleh orang Kanaan berbeda dengan Yahweh yang menampakkan dirinya kepada Musa. Perbedaan ini bahkan terus terjadi sampai dengan periode para hakim; di mana El dan Yahweh selalu dibedakan.

Naskah Laut Mati yang tergambar dalam teks Ulangan 32:8-9; "Ketika Sang Mahatinggi membagi-bagikan milik pusaka kepada bangsa-bangsa, ketika Ia memisah-misah anak-anak manusia, maka Ia menetapkan wilayah bangsa-bangsa menurut bilangan anakanak Israel. Tetapi bagian TUHAN ialah umat-Nya, Yakub ialah milik yang ditetapkan bagi-Nya." Menurut Smith teks ini telah dipergunakan para pendukung argumentasi El dan Yahweh Allah tidak identik - sebagai bukti adanya pemisahan antara ke dua ilah tersebut di Israel. Menurut penulis, teks Laut Mati yang memiliki padanan dengan Septuaginta jelas menggambarkan Yahweh sebagai salah satu anak El - artinya El dan Yahweh merupakan dua Allah berbeda. Akan tetapi, dalam upaya gerakan eksklusivisme Yahweh oleh para nabi pembuangan dan pasca-Pembuangan, teks ini diubah dari "anak-anak Elohim" menjadi "anak-anak Israel" - konsep yang kemudian menjadi warna abadi teks Masoret.

${ }^{9}$ Douglas J. Baker, El ELohe Esrael? An Inquary Into The Alleged Background of Early Israelite Religion (Moody Bible Institute, 2004), 55-64

${ }^{10}$ Ibid., Smith, The Origin of Biblical Monotheism, 141 
Penggabungan atau fusi antara kedua ilah ini menurut Rainer Albertz, ${ }^{11}$ mungkin terjadi pada peristiwa Keluaran atau pada masa pendudukan Israel di Kanaan. Masyarakat penyembah El Kanaan bertemu dengan masyarakat penyembah Yahweh Keluaran dari Mesir; kedua kelompok religius ini kemudian bersatu dan pada akhirnya mereka sepakat menetapkan Yahweh atau El sebagai satusatunya Allah mereka dikemudian hari, yang kemudian berfusi pada era Hakim-Hakim; yang tergambar dalam nyanyian Debora. Kelihatannya Rainer Albertz yang berorientasi pada "Historicalcritical and social-historical," berbicara mengenai keberagaman sistem agama; termasuk ilah di Israel yang dikondisikan oleh struktur sosial yang ada. Yahweh yang merupakan Allah absolut Israel muncul dalam apa yang ia sebut religiongeschichte. Dengan kata lain Yahweh yang melepaskan Israel dari Mesir kemudian menjadi Allah utama di mana semua sejarah dan konteks sosial keagamaan Israel berada telah mengalami perkembangan dari satu bentuk kepada bentuk lainnya sampai berakhir kepada Yahweh yang kita kenal dalam bentuknya saat ini. Yahweh yang melepaskan Israel dari Mesir kemudian menjadi Allah utama di mana semua sejarah dan konteks sosial keagamaan Israel berada.

Pemikiran Albertz di atas, merupakan modifikasi sekaligus satu langkah lebih maju dari pemikiran Albrecht Alt yang lebih menekankan pada penelitian sejarah agama ketika meneliti agama Patriak. Menurut Alt, Walaupun penyusun kitab Kejadian menempatkan Yahweh serupa dengan Allah Abraham, Allah Ishak dan Allah lainnya, bagi Alt semua nama tersebut berbeda - dengan ilah berbeda - yang kemudian menjadi sebutan untuk ilah yang sama. Realitasnya, pada fase awal agama para Patriak menyembah Allah leluhurnya dengan nama 'Pahad Yitzak' dan 'yang Kuat Yakub,' atau yang dikenal dengan 'Allah Ishak dan Allah Yakub,' juga ada Allah

${ }^{11}$ Rainer Albertz, A History of Israelite Religion, (Westminster: John Knox Press 1992), 77 
ketiga yang disebut dengan Allah Abraham. Ketiga Allah berbeda ini disembah oleh tiga suku berbeda dalam periode nomaden mereka sebelum masuk ke tanah Kanaan.

Suku-suku berbeda ini kemudian masuk Kanaan dalam waktu yang berbeda. Suku Yakub dengan 'Abir Yakub' merupakan suku terbesar dan berdiam di Utara Kanaan. Suku Ishak dengan 'Pahad Yitzak' berdiam disekitar Beersheba, sedangkan suku Abraham dengan 'El Elohe Abraham' berdiam di sekitar Mamre. Dengan berjalannya waktu, El Allah Kanaan kemudian perlahan-lahan mulai diidentikkan dengan Allah para Patriak tersebut di atas. Hasilnya, muncul nama baru dari Allah sesembahan mereka - bukan saja Allah Yakub atau Allah Ishak, tetapi muncul pula istilah 'El Elohe Israel sebagai nama resmi Allah bagi kumpulan suku-suku Keluaran Mesir tersebut. Suku-suku ini lebih lanjut melakukan semacam poling dan merekonstruksi sejarah mereka sehingga satu dengan lainnya berhubungan. Abraham menjadi 'kakek' disusul Ishak dan Yakub. Allah-Allah mereka kemudian secara simultan mengalami identifikasi satu dengan lainnya, sehingga kitab Kejadian ketika berbicara mengenai Allah Abraham dan Allah Ishak - berbicara mengenai Allah yang identik. Di waktu mendatang Musa kemudian memanggil nama Allah para Patriak dengan sebutan Yahweh sebagai Allah nasional Israel - dengan pemikiran Yahweh adalah El yang disembah bersama-sama di kuil-kuil Israel. ${ }^{12}$

Pemisahan Yahweh dengan El dalam konsep Albertz dan Alt - bahwa kedua ilah tersebut tidak identik berdasarkan kultur dan landasan geografis, tidak berjalan aklamasi. Mark S. Smith berargumen bahwa Israel pada masa awal Jaman Besi I tidak berbeda dengan masyarakat Kanaan pada umumnya; Beberapa ilah yang disembah orang Israel saat itu merupakan tipikal ilah-ilah yang umum disembah masyarakat Syro-Palestina. El, Yahweh, Ba'al dan Ahserah

12 Albrecht Alt, Essay on Old Testament History and Religion, (Sheffield Academic Press, 1989), 3-77 
merupakan Allah-Allah orang Israel yang juga disembah oleh orang Kanaan; penolakan terhadap kultus mereka yang terjadi pada abad 7-6 SM, justru mendemostrasikan bahwa kultus para dewa dan dewi ini nyata dan menjadi ancaman bagi konsep monoteisme. Kemiripan budaya yang dimiliki Israel dengan budaya sekitarnya menuntun pada pengertian: Israel dengan Ugarit memiliki budaya sejajar karena berasal matriks yang sama. Hal ini terlihat dari beberapa bentuk budaya Israel yang secara spesifik merupakan echo dari budaya Ugarit (Kanaan) yang mendahuluinya. Untuk itu, teks-teks Ugarit dapat disebut sebagai "Perjanjian Lamanya Perjanjian Lama." Berdasarkan argumentasi ini, Israel tidak lagi disebut "Israel di tengah-tengah bangsa-bangsa Timur dekat kuno (Kanaan).” Sebaliknya, mereka lebih pantas disebuts "Israel dan bangsa-bangsa Timur dekat kuno (Kanaan)."13 Implikasi dari argumentasi di atas menempatkan Yahweh dan El tidak pernah berasal dari luar Kanaan - melainkan menjadi bagian intrinsik dari kultur Kanaan - di mana Israel sejak semula merupakan bagian dari budaya ini. Bagi Smith, Allah asli Israel adalah 'El.'

Penulis melihat ada indikasi El dan Yahweh berjalan beriringan pada awal-awal kerajaan dengan tidak ditemukannya polemik antara El dan Yahweh dalam kitab Ibrani. Nampaknya pada awal-awal kerajaan, tradisi Israel melihat El sejajar dengan Yahweh atau mempersamakan keduanya, namun kedua ilah tersebut tidak identik. Bahkan pemisahan El dengan Yahweh semakin jelas ketika Smith menyusun sistem Panteon Ugarit dalam hubungannya dengan Panteon Israel. Susunan yang dibuat Smith menempatkan allah Level pertama Panteon Ugarit dihuni oleh El dan pasangannya Atirat/ Asherah. Level kedua dihuni oleh Ba'al, Anat, Yahweh, Yamn dan Mot. Susunan Panteon Ugarit ini dapat terlihat dalam Panteon Israel

13 Mark S. Smith, The Early History of God: Yahweh and Other Deities in Ancient Israel, ' (Michigan: Grand Rapids, MI.: Eerdsmans, 2002), 64, 75. 
yang menempatkan El sebagai Ilah utama disusul oleh Yahweh dan ilah lain pada level berikutnya.

Pemikiran dan argumentasi mengenai Yahweh dan El sebagai Allah tidak identik, mendapat tantangan dari Michael S. Heisser. Bagi Heisser, El dan Yahweh sejak semula merupakan ilah identik - bahkan pandangan ini tetap bertahan sampai era Pembuangan. Bagi Wellhausen dan Heisser - utamanya Heiser yang mempergunakan Ulangan 32 dan Mazmur 82 sebagai dasar argumentasi - percaya bahwa Yahweh dan El adalah ilah identitk sejak semula. Memisahkan El dan Yahweh dalam konteks Ulangan 32:8-9 secara internal tidak konsisten dengan pasal Ulangan 32 dan keseluruhan kitab Ulangan. Kepastian ini didemonstrasikan dalam dua Ulangan 32 ayat 6 dan 7. Menurut Heisser, kedua ayat tersebut memberikan rujukan paling kurang lima pengakuan terhadap epitet El kepada Yahweh yang mendemonstrasikan sang redaktur yang menyusun Ulangan mengenal kesatuan antara El dan Yahweh dalam sistem agama Israel.

Jika menelaah Deuteronomy secara luas; misalnya Ulangan 4:19-20 yang paralel dengan Ulangan 32:8-9, kita menemukan informasi tentang Yahweh yang 'mengambil' (jql) Israel sebagai miliki pusakanya (lihat Ul. 9:26, 29; 29:25). Teks ini menurut Heisser jelas menggambarkan Israel yang tidak diberikan kepada Yahweh; suatu tafsiran yang dipercaya oleh para evolusionis sebagai teks pemisahan antara EL dengan Yahweh. Bagi Heisser, Ulangan 32:9 merupakan bukti tidak pernah ada alasan gramatikal untuk menyimpulkan bahwa "Israel diberikan kepada Yahweh oleh El." Jika melihat hubungan antara Ulangan 32:8-9 dengan Ulangan 4:19-20, akan lebih konsisten apabila menafsir "Yahweh mengambil Israel bagi dirinya melalui tindakan berkuasanya."

Variasi tafsiran dan teori serta pengertian mengenai lahir dan berkembangnya agama Israel - khususnya konsep Yahweh dan El - dimulai dari kemunculannya, perkembangan, fungsi dan peran di 
Kanaan dan Israel - sampai periode monarki - seperti yang tergambar di atas, menjadi pergumulan penulis untuk diteliti; khususnya problematika seputaran tafsir atas teks-teks yang menjadi ladang argumentasi El dan Yahweh seperti Keluaran pasal 3 dan 6, Ulangan pasal 32 dan Mazmur 82, menjadi dorongan penulis untuk menyelidiki kedua Allah utama Israel tersebut.

Asumsi yang diajukan penulis adalah para Patriak dalam narasi Kejadian tidak pernah mengetahui Yahweh dengan nama ilahinya, mereka hanya menyembah El. Sementara itu, narasi Patriakal yang mungkin berakar dari abad kedua sebelum Masehi yang mana nama Yahweh muncul dan dimasukkan dalam teks; diasumsikan narasi tersebut telah diedit beberapa waktu kemudian setelah era Musa - di mana Keluaran 6:2-3 menyatakan bahwa Yahweh menyatakan namanya yang belum dinyatakan sebelumnya. Bukti-bukti selanjutnya telah menunjukkan bahwa El dalam narasi Patriakal mengalami semacam asimilasi dalam figur Yahweh (Albertz dan Alt), atau mengalami perkembangan ke arah monoteisme absolut - Yahweh semata; di mana El menghilang karena berfusi dalam Yahweh, dalam proses convergence and differentiation ala Mark S. Smith.

Penelitian ini dijalankan sebagi upaya untuk melakukan analisis terhadap muncul, peran dan berkembangnya El dan Yahweh di Israel; termasuk di dalamnya menjawab pertanyaan-pertanyaan seperti: apakah El dan Yahweh Allah identik? Apakah El Kanaan identik dengan El Allah Patriak ? Apabila diklaim El dan Yahweh berkembang atau berfusi; pertanyaannya adalah bagaimana dan sejak kapan kedua ilah berkembang dan berfusi di Israel?

Penelitian-penelitian terdahulu yang membahas muncul dan berkembangnya Yahweh dan El di Kanaan dan Israel oleh para sarjana ANE, seperti: Rainer Albertz, Van Der Torn, William Dever, Marks S. Smith, Albrecht Alt, W.F. Albright, atau F.M. Cross, 
menjadi materi rujukan penelitian dalam upaya memperkaya analisis teks yang dilakukan penulis dalam penelitian ini.

Berdasarkan latar belakang masalah di atas, penulis merumuskan beberapa masalah yang harus mendapat perhatian kita, antara lain: apakah El Kanaan yang tergambar dalam manuskrip Ugarit identik dengan El Allah Patriak dalam kitab Ibrani? Apakah Yahweh dan El adalah Allah identik dalam sistem agama Israel?Seperti apakah proses perjumpaan dan perkembangan; serta bagaimana proses bergabung dan berfusinya El dan Yahweh di Israel?

Untuk mendapat jawaban dari beberapa pertanyaan di atas, maka, penulis melakukan beberapa analisis sebagai berikut: pertama, melakukan deskripsi dan analisis figur EL yang tergambar dalam narasi Patriak dengan figur El dalam manuskrip Ugarit; dengan mempergunakan metode kritik historikal-literari-dialektis antara kedua sumber informasi tersebut; teks Ugarit dan teks Ibrani, dalam upaya mendapatkan jawaban apakah kedua ilah tersebut identik atau tidak. Hasil yang diperoleh dari penelitian ini kemudian dapat menjadi bahan rujukan untuk menetapkan asal-mula El sebagai Allah Patriak dalam hubungannya dengan El allah Kanaan dan dengan Yahweh. Kedua, Menganalisis apakah Yahweh dan El adalah dua ilah identik atau tidak dalam sistem agama Israel. Jawaban dari penelitian ini diharapkan dapat memberikan kontribusi bagi perkembangan penelitian Perjanjian Lama; khususnya menetapkan kesatuan atau keterpisahan Yahweh dan EL. Ketiga, Melakukan analisis perjumpaan antara Yahweh dan El dalam sistem agama Israel; terutama periode awal perjumpaan, yang dilanjutkan dengan menjawab pertanyaan bagaiman kedua figur ini berkembang di Israel - dan berfusi - di mana Yahweh muncul sebagai Allah tunggal pada periode bait Allah Kedua. Titik berat analisis adalah pada proses "perkembangan" Yahweh dan El sampai mereka berfusi, dengan mengabaikan pemikiran "saling mempengaruhi/pengaruh" satu dengan lainnya dalam sistem agama Israel seperti yang dianut kaum evolusionis. 
Manfaat yang dapat diperoleh dari analisis ini; khususnya analisis dari poin Yahweh dan El 'berkembang' (development) dan bukan mendapat pengaruh atau saling mempengaruhi (influence) dalam agama Israel - adalah kita dapat mengetahui bahwa Yahweh dan El; berikut Israel sebagai umatnya, tidak pernah lepas asalnya dari matriks Kanaan. Israel tidak bisa disebut "Israel di tengah-tengah bangsabangsa Timur dekat kuno (Kanaan).” Sebaliknya, mereka lebih pantas disebuts "Israel dan bangsa-bangsa Timur dekat kuno (Kanaan).

Untuk itu, asusmsi penulis dalam penelitian ini sangat berdasarkan pada argumentasi-argumentasi dari penemuan teks-teks ekstra-biblikal dan teks Perjanjian Lama itu sendiri yang memberikan gambaran jelas mengenai Allah Israel yang memiliki beragam ilah sesembahan - sekaligus nama dan julukan berbeda dari masingmasing ilah tersebut. Para ahli Anet telah buktikan bahwa para Patriak dan kaum Keluaran yang dipimpin Musa, memiliki Allah berbeda yang dikenal dengan nama El dan Yahweh. Hal ini memimpin pada substansi asumsi penulis bahwa berita mengenai kesejajaran $\mathrm{El}$ dan Yahweh dalam teks-teks Perjanjian Lama, merupakan karya kesejarahan yang dilakukan oleh para penulis Alkitab dalam kerangka teologis semata dan bukan dari sudut 'sejarah Agama Israel.'

Selanjutnya penulis mengambil proposisi (postulat) El sebagai Allah yang dikenal sekaligus sesembahan para Patriak pada periode awal sejarah Israel. Sedangkan figur Musa yang memiliki pengetahuan mengenai Yahweh (melalui orang Keni dan Midian), memproklamirkan Yahweh kepada kaum Keluaran Mesir ini. Beberapa suku di Kanaan dipercaya telah memiliki pengetahuan dan kepercayaan kepada Yahweh yang merupakan Allah selatan Palestina, kemudian mereka bergabung dengan suku-suku Keluaran Mesir tersebut.

Walaupun Yahweh kemudian menjadi Allah nasional Israel, Yahweh diketahui tidak serta-merta menjadi satu-satunya 
Allah. Setiap kelompok di Israel (bahkan Kanaan) menyembah banyak Allah. Bahkan Yahweh saat itu sering muncul dalam bentuk poli-Yahwisme yang beroperas dalam konteks masing-masing sukusuku tersebut. Sedangkan El dan Ba'al tetap terus bertahan dalam penyembahan Israel; terutama di Kerajaan Utara. Ketika Samaria Jatuh, banyak dari penyembah El dan Ba'al membawa kepercayaan mereka ke Yehuda dan memberikan pengaruh di sana. Dalam perjalanan waktu, Yahweh kemudian banyak menyerap atribut atau julukan yang sebelumnya dimiliki Ba'al dan El.

Jenis penelitian dipergunakan adalah metode "diakronik dan dialektik teologis Hegel." Metode Hegelian sederhananya adalah: A (thesis) versus $B$ (anti-tesis) equals $C$ (synthesis). Penulis melakukan analisis (tesis) dengan mengumpulkan instrumeninstrumen yang berhubungan dengan agama-agama Semit kuno; di dalamnya termasuk data mengenai El dan Yahweh yang diperoleh dari sumber teks Ibrani dan manuskrip ekstra-biblika yang kemudian diolah mendalam. Antitesisnya adalah melakukan analisis perjumpaan dan perkembangan El dengan Yahweh di Israel; dimulai dari era Musa, sampai dengan periode para nabi dan berakhir pada era Pasca Pembuangan. Sedangkan sintesanya muncul dalam nuansa agama Yahweh yang diprakarsai oleh kaum Deuteronomis dan Priest yang tetap membawa warna Elohis dalam Yahwistiknya.

Metode-metode lain yang dipergunakan penulis dalam buku ini adalah metode analisis sejarah - sosial dan kritik - sejarah, digabungkan dengan metode kritik literari - tradisi. Analisis dilakukan dengan meneliti teks-teks yang berhubungan dengan lahir, muncul dan berkembangnya El dan Yahweh di Israel, beserta segala konteks yang bersangkut-paut dengan literari, tradisi dan konteks sosial yang membentuk teks, yang dihubungkan dengan sejarah perkembangannya. Bagaimana sejarah, sastra dan tradisi kedua ilah tersebut terekam dalam konteks sosial dan sejarah yang kemudian membangun aliran teologia tertentu dikemudian hari. Selain beberapa 
metode di atas, penulis menggunakan analisis dari penemuan arkeologi dan teks Ibrani untuk mendapat pengertian baru mengenai sistem agama Israel. Bagi penulis, teks Ibrani yang merupakan sumber soft data digabungkan dengan hasil penemuan arkeologi yang adalah hard data - factual information, dapat memperdalam kualitas argumen dari penelitian ini. Pada akhirnya penulis mengingatkan bahwa Penelitian ini tidak dilakukan dalam kerangka (framework) analisis dogmatis dan teologis, mengingat yang diteliti penulis adalah agama Israel - Yahweh dan El yang dipraktekkan masyarakat Israel kuno dan bukan persepsi atau paradigma dari penulis kitab Ibrani. 


\section{Bab II}

\section{Kebangkitan Yahwisme Di Monarki Israel}

Para sarjana ANET terbagi dalam dua kelompok ketika menentukan asal-mula El dan Yahweh serta hubungan antar keduanya dalam sistem agama Israel; yaitu antara penganut teori El dan Yahweh sebagai ilah identik, melawan penganut teori El dan Yahweh ilah berbeda. Pendukung teori Yahweh dan El ilah berbeda berargumentasi perbedaan keduanya karena Yahweh merupakan Allah yang asli beroperasi di wilayah Selatan Palestina - yang berbeda dengan El yang mayoritas beroperasi di wilayah Utara Palestina. Keterangan Yahweh yang muncul dari Selatan Kanaan terlihat dari teks-teks Perjanjian Lama itu sendiri yang menggambarkan sang ilah muncul dari Seir, Sinai dan Paran, yang kemudian ditemukan Israel dalam perjalanan keluaran dari Mesir dan dibawa ke Kanaan. Di tanah Kanaan, Yahweh digambarkan bertemu dengan aliran Yahweh yang telah beroperasi di wilayah Kanaan - sekaligus bertemu dengan kelompok penyembah El yang disembah orang Kanaan dan para Patriak. Di tanah Kanaan, figur El dan figur Yahweh menjadi Allah sesembahan utama Israel tanpa ada persoalan dari para penyembahnya. Akan tetapi pada era Pembuangan dan pasca Pembuangan, El mulai menghilang dan Yahweh bertransformasi menjadi Allah dominan Israel. Menurut Mark S. Smith:

"The original god of Israel was El. This reconstruction may be inferred from two pieces of information. First, the name of Israel is not a Yahwistic name with the divine element of Yahweh, but an El name, with the element 'el. This fact would suggest that El was the chief god of the group named Israel. Second, Genesis 49: 24-25 presents a series of El epithets separate from the mention of Yahweh in verse 18. Yet, early on, Yahweh is understood as Israel's god in 
distinction to El. Deuteronomi 32:8-9 casts Yahweh in the role of one of the sons of El, here called Elyon..."14

Lebih jauh Smith melihat Israel bukan sebatas berbagi kultur dengan orang Kanaan yang digambarkan berdiam di sekitarnya, melainkan Israel 'naturnya' memang berasal dari Kanaan. Budaya Israel secara alami merupakan budaya Kanaan, untuk itu kita tidak dapat mempertahankan ide "perpisahan" budaya antara Israel dan Kanaan pada periode jaman Besi 1. Konsep Perjanjian Lama mengenai Allah di Israel muncul secara 'berangsur-angsur' dalam suatu proses yang disebut Smith convergence and differentiation "kebersatuan dan perbedaan." Istilah convergence ini dapat dipahami sebagai upaya melakukan "penggabungan karakter-karakter keilahian; bahkan kepada ilah itu sendiri, masuk atau menuju ke dalam figur Yahweh" (coalescence of characteristic of deities, an even the deities themselves, into the depiction of Yahweh). Proses ini jelas terlihat di era Hakim-Hakim, pada awal-awal monarki dan pada era Bait Allah Kedua ketika El dan Yahweh mulai diidentikkan satu dengan lainnya; bahkan Asherah mulai dilihat sebagai satu kesatuan dengan Yahweh sekaligus simbolnya menjadi bagian dari kultus Yahweh.

Berdasarkan analisis di atas, Smith melihat sejarah Israel tidak berjalan dalam satu proses seperti yang dianut kaum evolusionis (Alt). Perubahan tidak terjadi melalui proses evolusi, melainkan melalui proses differentiation and convergence. Pada tahap awal perkembangan agama; terutama pada era awal Jaman Besi I, Israel tidak berbeda sama sekali dengan budaya Kanaan - Israel bagian dari budaya Kanaan. Ilah-ilah yang disembah Israel merupakan ilah-ilah yang disembah orang Kanaan saat itu. ${ }^{15}$ Menurut Smith, semua praktik keagamaan yang diupayakan oleh para penulis Alkitab Bait

${ }^{14}$ Mark S. Smith, The Early History of God, Yahweh and the Other Deities in Ancient Israel, (Harper and Row, Publisher, San Fransisco: Grand Rapids, 1990), 7-11

${ }^{15}$ Ibid., 64 
Allah Kedua sebagai bukan bagian dari Israel, sesungguhnya merupakan bagian dasar dari budaya dan sistem agama Israel itu sendiri. Israel merupakan suku penyembah Asherah yang terekam dalam teks Yeremia 17:2 "anak-anak Israel ingat terhadap altar dan Asherah mereka..."16 Mereka bahkan digambarkan melakukan korban persembahan anak yang dihubungkan dengan korban persembahan kepada Yahweh "mlk sacrifice."17 El, Asherah, Ba'al, atau Anat, merupakan ilah-ilah sesembahan Israel yang sah atau legal saat itu. Mereka semua disembah dalam konteks Sidang Ilahi di mana El menjadi Allah utama dan Yahweh yang lebih sering berada dalam posisi Allah level kedua.

Sedangkan differentiation, menekankan pada penolakan kultus lama Israel karena dianggap sebagai budaya Kanaan. Tradisitradisi yang dihubungkan dengan Ba'al, Asherah, penyembahan benda-benda angkasa (tata surya) dan Bamot dianggap (ditetapkan) sebagai non Yahwistik. Dengan ideologi differentiation inilah, maka, baik pihak kerajaan maupun nabi-nabi profetik mulai mengembangkan ideologi Monolatri yang kemudian berkembang menuju Monoteisme. Dalam konteks differentiation ini, Smith menggambarkan bagaimana tradisi Priestly dan Deuteronomis melakukan sensor ketat terhadap tradisi Israel - yang mengalami sensor paling keras adalah tempat-tempat suci di mana konsep Sidang Ilahi dipraktikkan. ${ }^{18}$ Upaya ini semakin gencar dan luas pada era Bait Allah Kedua yang terekam dalam teks-teks Qumran dan teks-teks Apokaliptik. Yahweh bertransformasi menjadi Allah utama menggantikan El yang sebelumnya sebagai Allah Utama Israel bersamaan dengan lenyapnya konsep Sidang Ilahi Israel. Menurut Smith, "perkembangan" Kitab Ibrani dalam sejarah dipenuhi dengan

${ }^{16}$ Ibid., Smith, The Early History of God. 110

${ }^{17}$ Ibid., 172

${ }^{18}$ Reformasi Yosia merupakan gambaran jelas penghapusan konsep Sidang Ilahi beserta kultus-kultus di mana konsep ini beroperasi. 
konflik dan kompromi antara beberapa aliran imam dalam kepenulisannya. ${ }^{19}$

Monoteisme bukan merupakan hasil dari perkembangan evolusi menuju satu bentuk agama yang superior, melainkan melalui proses bagian demi bagian dalam proses differentiation dari bentuk sebelumnya yang convergence model agama asli Israel yang politeistik. Berdasarkan analisis Smith ini, penulis melihat sejarah Agama Israel tidak pernah hadir dalam frame work evolusi model Alt dan Albright, atau dalam model dialektik antara sejarah dan mitos yang dikembangkan Cross. Smith melihat sejarah Israel tidak pernah berkembang dalam satu perkembangan tunggal, melainkan sejarah agama mereka masuk dalam ranah sejarah melalui upaya "mengingat, menemukan dan melupakan: (remembering, inventing, and forgetting) beberapa dimensi penting dari sistem itu sendiri. Model pendekatan ini pada akhirnya membuat perbedaan antara geschichte (what really happened) dengan Heilsgeschichte (the way the culture attempts to represents what really happened). Menurut Smit, "sejarah Israel" hanya hadir dari keberlanjutan dengan cerita-cerita yang terekam dalam kumpulan ingatan (collective memoriy). ${ }^{20}$

Frank Moor Cross memiliki argumentasi berbeda dengan Smith. menurut Cross, Yahweh dan El menjadi identik disebabkan absennya perbedaan jelas antara kedua ilah tersebut dalam sistem agama Israel. Implikasi dari pernyataan Cross di atas: Yahweh dan El pada mulanya identik - terpisah - bergabung kembali menjadi Yahweh saja; dengan kata lain nama El dan Yahweh selalu merujuk pada Allah yang sama - entah ketika ia disembah sebagai El atau Yahweh di Kanaan dan Israel. Sedangkan Jullius Wellhausen tetap percaya bahwa sebelum era para nabi, Allah Israel adalah Allah suku yang terdiri dari Yahweh dan El - yang ia aminkan sebagai figur identik - yang muncul dalam bentuk Monolatri dan henoteisme

${ }^{19}$ Ibid., Smith, The Early History of God, 205

${ }^{20}$ Ibid., xxviii 
bersama dengan ilah lainnya melalui pemberitaan para nabi. ${ }^{21}$ Pandangan Welhausen di atas mendapat dukungan Michael S. Heisser beberapa dekade kemudian. Menurut Heisser, konsensus El dan Yahweh yang digambarkan sebagai ilah terpisah memiliki kelemahan serius dalam tataran eksegesis dan historikal. Bagi Heisser, pemisahan kedua ilah tersebut menunjukkan inkonsistensi secara internal; baik dalam teks Ulangan 32 maupun kitab Ulangan secara umum. Heisser mengklaim dalam Ulangan 32:6-7 terdapat sekurangkurangnya lima hal yang memperlihatkan pengakuan julukan El kepada Yahweh. Teks ini mendemonstrasikan adanya kesatuan antara El dan Yahweh dalam sistem agama Israel. Beberapa sebutan yang menunjukkan ke-samaan keduanya adalah ' $a b$ 'adm (father of mankind), tr 'il 'abh 'il mlk dyknnh (Kerbau El ayahnya, El raja yang mentapkannya) dan 'l qny'rs (El, pencipta Dunia). Dalam hal ini Yahweh digambarkan sebagai "Allahmu" yang menetapkan engkau," Yahweh juga yang "menciptakan” (ay.6). ${ }^{22}$ Bahkan dalam kacamata redaksi Deuteronomi, bangsa Israel yang melakukan praktik penyembahan Monolatri terhadap satu ilah utama Yahweh-El yang memimpin atas seluruh sidang ilahi 'anak-anak Elohim' merupakan suatu keniscayaan. Menurut Heisser, Deuteronomi masih tetap dalam kepercayaan kepada model sidang ilahi 'bene Elohim,' namun tidak serta-merta menetapkan Yahweh dan El sebagai dua ilah berbeda. Itulah sebabnya, Heisser melihat munculnya kelas tertentu dalam Sidang Ilahi yang tercatat dalam Ulangan 32 tidak perlu dipermasalahkan. Argumentasi yang ia ajukan adalah: pertama, Ulangan 32 dan Mazmur 82 merupakan teks retorik yang berfungsi untuk meyakinkan orang Israel bahwa Yahweh pada akhirnya menjadi

21 J. Welhausen, Prolegomena to the History of Ancient Israel, trans J.S. Black and A. Menzies, (Edinbur: A. C. Black, 1885), 433

${ }^{22}$ Michael S. Heiser, The Divine Council in Late Canonical and Non Canonical Second Temple Jewish Literature, (Madison: University of Wisconsin, 2008), 78-80 
Tuhan dari segala tuhan. Kedua, Bait Allah Kedua yang menunjukkan pluralitas dalam bene Elohim atau olam yang bagi Heisser sebatas berbicara mengenai anggota sidang ilahi kelas bawah dibandingkan dengan ilah-ilah yang tercantum dalam konstelasi sidang ilahi sebelum pembuangan. ${ }^{23}$ Worldviews dan sistem monalatri ini terus konsisten sepanjang sejarah Deuteronomi dan terpampang abadi dalam literatur periode akhir pasca Pembuangan Israel.

Perbedaan argumentasi tentang sosok El dan Yahweh dalam sistem agama Israel di atas akan dijabarkan dan dianalisis dalam bab ini untuk mengetahui apakah El dan Yahweh adalah dua ilah berbeda dalam sistem agama Israel atau apakah kedua figur tersebut dapat disebut sebagai ilah identik sejak mulanya berdasarkan berita dalam teks Ulangan 32, Mazmur 82 dan Keluaran pasal 3 dan 6; di mana kedua pasal terakhir kitab Keluaran tersebut terlihat memberikan sinyal hadirnya pertemuan El dengan Yahweh yang diklaim sebagai Allah Israel.

\subsection{Monoteisme Israel}

Teks Perjanjian Lama mengasumsikan adanya dunia politeistik universal di Israel. Literatur Israel kuno yang muncul sering merupakan refleksi dari suatu sistem kepercayaan yang bervariasi; daripada sekedar bentuk monoteistik kaku dengan keberadaan dari satu Allah saja, sedangkan allah-allah lain merupakan delusi semata.

Para ahli biblika kontemporer cenderung melihat munculnya Monoteisme di masyarakat Israel kuno sebagai fenomena perkembangan terkemudian yang bersifat gradual. Pada dasarnya pandangan kritis ini berlandaskan pada ide bahwa "Monoteisme hanya samar-samar terlihat dalam masyarakat Israel sebelum pembuangan." Monoteisme yang lebih konsisten dipandang sebagai produk

${ }^{23}$ Ibid., Heiser, The Divine Council, 78-80 
masyarakat Israel pembuangan yang bereaksi terhadap pembuangan yang mereka alami di Babel dan Asyur.

Melalui beberapa diskusi pada abad terakhir ini, para ahli ANET sering menggunakan beberapa frasa tertentu, seperti: Henoteisme dan Monalatri untuk menjelaskan bagaimana munculnya Monoteisme. Gambaran Henoteisme dan Monolatri dapat terlihat dari teks-teks Perjanjian Lama seperti dalam kalimat Keluaran 15:11 "siapakah yang seperti engkau di antara para Allah, ya Tuhan (elohim)?" Keluaran 20:3 "jangan ada padamu Allah lain selain aku." Ulangan 32:8-9 "ketika sang maha tinggi (elyon) menetapkan bangsabangsa/ ketika ia membagi manusia/ dia menetapkan batas-batas bagi umatnya menurut jumlah anak-anak Allah (bene elohim). Mazmur 95:3 "sebab Tuhan adalah Allah yang besar, dan raja besar yang mengatasi segala Allah (elohim).

Dengan memperhatikan beberapa ayat dalam teks Ibrani seperti disebut di atas, maka sangat sulit bagi kita untuk memikirkan konsep Monoteisme dalam masyarakat Israel pra-pembuangan. Dekalog dengan jelas mencuatkan ide ada Allah lain selain Yahweh dalam taklimat pertamanya "jangan ada padamu Allah lain selain aku..." Nyanyian Israel dalam Keluaran 15 “...tidak ada Allah lain sepertimu...", juga kita melihat kehadiran dewa Kanaan Resep dan Deber yang menjadi bagian dari kampanye militer Yahweh dalam Habakuk 3:5, dan masih banyak teks kitab Ibrani lainnya yang memuat berita mengenai keberadaan Allah-Allah selain Yahweh yang disembah umat Israel, yang mengindikasikan bahwa Israel mengetahui adanya Allah lain selain Yahweh - sekaligus tidak menolak keberadaannya. Selain itu, teks Keluaran 20 dan Ulangan 5 yang memiliki perintah positif 'jangan ada padamu allah lain dihadapanKu', semakin menguatkan ide Monolatri dalam aras beragama Israel kuno.

Para ahli sejarah agama Israel abad 19 yang menggunakan metode Darwinian sebagai landasan menelaah 
Monoteisme Israel, mengembangkan pemikiran "evolusionis" dalam menjelaskan sistem agama Israel. Para ahli tersebut menggambarkan perkembangan agama Israel melalalui beberapa tangga evolusi yang kemudian bermuara ke dalam bentuk Monoteisme etis yang sepenuhnya. Julius Welhausen (1878) dan Robertson Smith (1889) merupakan punggawa dari model ini. Akan tetapi ide "evolusi" ini mendapat perlawanan para ahli biblika sekitar 60-70 tahun kemudian dengan argumen agama Israel tidak mengalami “evolusi” seperti yang diklaim Welhausen. Para ahli tahun 1940-an ini mengembangkan metode "revolusi" dengan dalil: sejak semula Musa dengan umat Israel adalah murni pemegang ajaran Monoteisme. Monoteisme Israel telah terlihat semenjak bangsa ini berada di Mesir dan berlanjut di Kanaan. Warna Politeisme yang mereka miliki di Kanaan dipandang sebagai dampak bertemunya agama Yahweh dengan agama El yang beroperasi di Palestina. Ada suatu masa di mana Israel tertarik untuk menyembah para dewa di Kanaan (El, Ba'al, Asherah dan lain sebagainya), tanpa meninggalkan kepercayaan mereka kepada Yahweh. Para pengusung dari metode evolusi di atas yang paling terkenal adalah William Foxwel Albright. ${ }^{24}$ Albright berbicara mengenai adanya perbedaan besar antara kedua sistem agama Kanaan dan Israel; bahwa sistem agama Kanaan menempati level rendah apabila dibandingkan dengan sistem keagamaan Israel. Ia menyebut agama Kanaan sebagai agama "magis" dan "a-moral." Pernyataan ini diperkuat oleh muridnya Ulf Oldenburg, ${ }^{25}$ yang menyatakan: "semakin lama saya mempelajari agama Israel kuno, semakin saya menyadari sifat busuk dan jahatnya." Kemunculan Yahweh menghapuskan kegelapan mistik Kanaan. Dalam model analisis ini,

24 Lihat buku W.F. Albright, Yahweh and the Gods of Canaan, (Indiana: Eissenbraus, 1968); The Archaeology of Palestine and The Bible; From The stone Age to The Christianity (1940), dan Monotheism and the Historical Process (1940)

${ }^{25}$ Ulf Oldenburg. The Conflict Between El and Ba'al in Canaanite Religion (Leiden:E.J. Brill, 1969), xxxvii 
skisma antara Politeisme Kanaan dengan Monoteisme Israel terlihat jelas. Agama murni Israel dipercaya mengalami pengaruh dari agama Kanaan dan sebagai akibatnya terjadi sinkretisme antara agama murniMonoteisme Israel dengan agama kafir politeis Kanaan ketika kedua suku bangsa tersebut bertemu di Kanaan. Pendekatan revolusionis ini membuka pintu hadirnya para teolog Kristen mulai dari tahun 1940-an sampai dengan tahun 1970 dalam gerakan "biblika teologi," suatu pergerakan yang sangat dipengaruhi oleh aliran neo-orthodox - yang juga memberikan reaksi negatif terhadap perkembangan teologi liberal dan model evolusi Welhaussen yang masih samar-samar terlihat pada era itu. Penekanan kepada Allah yang bekerja (bertindak) dalam sejarah Manusia - seperti dalam peristiwa Keluaran, Sinai, penguasaan tanah Kanaan dan berita mengenai Yesus, merupakan pusat dari berita teologi biblika yang berbicara mengenai Alkitab sebagai sejarah keselamatan.

Selanjutnya muncul pendekatan lain yang menekankan pada metode menggabungkan ilmu ilmu sosial dengan antropologi. Dalam hal ini kita melihat ada karya Vogelin: Israel and Revelation, disusul Roland De Vaux dengan Social Instituions dan Religion Institution, yang dapat dikatakan sebagai karya terbesar bidang sosialantropologi saat itu. Setelah itu ada WC. Graham dan HG. May: Culture and Concience: an Archaelogical Study of a New Religious Pas in Ancient Israel, 1933. Juga ada karya G. Mendenhall dan B. Halpern sebagai pioner ide "peasant revolt" (pemberontakan kaum tani) untuk menjelaskan asal mula orang Israel di Kanaan, serta karya D.N. Freedman dengan The Emergence of Ancient Israel, 1983. Namun yang paling fenomenal dari karya sosio-antropologi dari para ahli ANET di atas adalah buku The Tribes of Yahweh karya Gottwald; yang dapat dipandang sebagai era baru penyelidikan budaya Israel yang mempergunakan ilmu sosial. Hal ini dimungkinkan dengan semakin disadarinya bahwa setiap literatur (teks biblika) selalu dibentuk dari, dengan atau melalui faktor-faktor sosial, agama dan 
ideologi yang dipengaruhi oleh kekuatan-kekuatan sosial yang ada. Para ahli di atas lebih memberikan perhatian khusus kepada proses serta bagaimana suatu sistem serta praktek kepercayaan yang dinyatakan sebagai hasil refleksi atau merefleksikan kekuatan politik dan ekonomi; sekaligus merefleksikan fungsi sosial dari kepercayaan dan praktek keagamaan itu sendiri beroperasi.

Pada akhirnya kita melihat muncul satu pendekatan yang disebut metode "development" yang merupakan upgrading model revolusionis yang berbasis kepada penggabungan data penemuanpenemuan arkeologi yang digabungkan dengan pendekatan sosialsains. Teori development agama Israel ini mendapat dukungan besar dari hasil penemuan arkeologi yang membuktikan adanya keragaman dan kompleksitas dari praktek kultus Israel; termasuk di dalamnya penyembahan terhadap dewi Asherah yang merupakan ilah kesuburan yang dihubungkan dengan Yahweh serta ilah-ilah lainnya seperti penyembahan kepada dewa-dewa bintang, bulan dan matahari, persembahan korban manusia yang disertai hadirnya kultus prostitusi. Informasi yang diperoleh dari interpretasi atas beberapa penemuan arkeologi berupa inskripsi di Kuntilet Ajrud dan Khribet el Qom menjadi pemicu lahirnya kaum "developmentaris." Dalam ranah interpretasi, penemuan dokumen Ugarit di atas memunculkan ide bahwa umat Israel dan penduduk Kanaan memiliki ikatan yang sangat dekat dikarenakan kedua komunitas tersebut berasal dari kultur dan milleu yang sama. Untuk itu, beberapa analisis ahli ANET; khususnya yang menggunakan model "developmentari" dalam menelaah Monoteisme Israel; dipajang penulis di bawah ini.

Menurut Morton Smith, ${ }^{26}$ ide mengenai "Yahweh semata" (Yahweh only) yang diinisiasi reformasi Deuteronomis; yang merupakan pergerakan religious dan politik kaum minoritas pada era pra Pembuangan, merupakan bentuk perlawanan terhadap bentuk

${ }^{26}$ Morton Smith, 'On the Shape of God and the Humanity of Gentiles', in Religions in Antiquity, Jacob Neusner, ed., (Leiden, Brill, 1968), 315-326 
agama popular ${ }^{27}$ dan kultus-kultus resmi yang aktif di Israel dan Yahuda saat itu; yang merupakan bentuk agama umum pada periode tersebut. Mayoritas orang Israel menyembah Yahweh sebagai Allah yang kuasa dengan tetap menyembah Allah lain. Smith mencatat ada tiga tahap perkembangan dari pergerakan kaum minoritas Yahwistik ini, pertama: pada mulanya kultus Yahweh tidak dibedakan dari bentuk tipikal agama Semit Barat. Setiap daerah memiliki Allah nasional dan Yahweh merupakan Allah nasional Israel. Kedua: wangsa Yehuda yang dimulai pada era sekitar tahun 1000 sebelum Masehi dianggap Smith sebagai bertanggung jawab atas penyebaran agama Yahweh di tengah-tengah khalayak ramai. Pada masa ini penyembahan terhadap para ilah sangat bervariasi termasuk di dalamnya penyembahan kepada El, Ba'al, Anat, Asherah dan dewadewa lainnya. Ketiga: para nabi klasik dan kaum reformis Deuteronomist memperkenalkan praktek Monoteisme kepada umat Israel dan Yehuda, namun Smith tetap melihat bahwa Monoteisme merupakan partai minoritas saat itu - bahkan pada era Yosia sekalipun. Pada akhirnya di era pembuangan; di mana umat Israel dikelilingi dan dikuasai oleh bangsa-bangsa asing, Israel menjadi semakin kuat dalam faham Monoteismenya dan menjadi (dipergunakan) sebagai alat pembeda dengan bangsa sekitarnya. ${ }^{28}$

27 "Bentuk alternatif ekspresi keagamaan yang non-ortodoks, nonkonformis, non-institusional, yang berada di luar kontrol jangkauan para imam dan Negara. Bentuk agama ini khususnya muncul di kalangan kaum minoritas yang terabaikan-seperti kaum wanita, orang asing dan anak-anak. Agama popular lebih berfokus kepada kebaikan individual dan praktek informal daripada ritual-ritual publik; juga lebih menekankan kepada kultus daripada formasi intelektual (teologi). Lihat William G. Dever. 'The Contribution of Archaeology to the Study of Canaanite and Early Israelite Religion, in Early Israelite Religion: Essays in Honor of Frank Moore Cross, ed. P.D. Hanson, P.D. Miller, S. Dean McBride ( Philadelphia: Fortress, 1987), 220

${ }^{28}$ Ibid., Smith, 'On the Shape of God and the Humanity of Gentiles, 315-326 
Gösta Ahlström, ${ }^{29}$ melihat teks-teks biblikal tidak bersaksi mengenai aktivitas Yahwisme murni selain merefleksikan bentuk natural dari suatu aktivitas keagamaan di Israel. Penyembahan terhadap ilah-ilah lain selain Yahweh - bahkan penggambaran Yahweh melalui patung-patung - merupakan bentuk ekspresi keagamaan normal agama politeistik Israel saat itu. Agama Israel adalah satu bentuk kultus nasional dengan satu Allah yang berkuasa dengan Yahweh, para dewa artisan seperti Asherah, Baal, dewa Matahari (Shamash) dan dewa Bulan (Yareah) yang digambarkan berkuasa bersama-sama. Agama ini beroperasi melalui kultus negara di mana penekanan terhadap ilah nasional bergantung kepada kebijakan raja yang berkuasa. Hizkiah dan Yosia pada masanya memperkenalkan Allah Yahweh sebagai Allah nasional sebagai bentuk keputusan politis di Yehuda. Setiap bamot yang tersebar di seantero Israel dan Yehuda memiliki interpretasinya masing-masing terhadap figur Yahweh (yang dibuktikan dengan sebutan berbeda terhadap Yahweh yang tercatat dalam inskripsi Kuntillet Ajrud dan Khirbet-el Qom). Ide Monoteisme pada era ini tidak menjadi pilihan Israel. Bagi Ahlström mereka lebih tepat disebut sebagai penganut Monolatri.

Nikiprowetsky, ${ }^{30}$ melihat tidak ada bukti Monoteisme di seluruh dunia Timur Dekat Kuno maupun di Israel sampai dengan masa Israel masuk dan berada di Pembuangan. Bahkan pada era Pembuangan, diketahui banyak dari kaum pasca-Pembuangan Israel; seperti kelompok yang terdapat di Elam-Mesir - tetap politeistik paling tidak mereka poli-Yahwisme. Namun demikian,

${ }^{29}$ Gösta Ahlström, 'King Jehu--A Prophet's Mistake', in Scripture in History and Theology, Arthur Merrill and Thomas Overholt, eds., (Pittsburgh Theological Monograph Series 17, Pittsburgh, Pickwick, 1977), 52-61. 68-89. 
Nikiprowetsky melihat ada pendahuluan terhadap terbentuknya Monoteisme yang dapat dilacak pada era sebelumnya - misalnya pada era di mana Yeroboam membangun kultus di Bethel dan Dan pada sekitar tahun 930 SM yang mengindikasikan bahwa Yahweh dapat menjadi Allah bagi Israel maupun Yehuda; sekaligus membuka peluang universalisme Yahweh. Bahkan ketika melihat berita para nabi Yahweh seperti Amos dan Yesaya kepada bangsa lain -berita mereka pada dasarnya telah membuka peluang universalisme Yahweh yang kemudian bermuara kepada Monoteisme.

Herman Vorländer, ${ }^{31}$ percaya Monoteisme Israel lahir pada era pembuangan; sebelumnya tidak pernah ada perbedaan antara agama Israel dan agama Kanaan. Bagi Vorländer, Israel bahkan tidak pernah identik dengan henoteisme dan monalatri, melainkan bentuk pluralisme Allah sesembahan umat ini menjadi alasan utama Israel lebih cocok disebut sebagai penganut Politeisme. Alasan Vorländer percaya bahwa Monoteisme murni hanya lahir di tengah umat Israel era Pembuangan lebih berdasarkan status minoritas Israel saat itu dan oleh karena itu membawa mereka lebih mendefinisikan diri secara religious dalam kerangka menjaga identitas ethnik mereka.

Norbert Lohfink, ${ }^{32}$ melihat selalu ada bentuk Monoteisme atau Monolatri laten dalam ragam Politeisme masyarakat Timur Dekat Kuno, namun kemunculan dan perkembangan mendadak Monoteisme tidak pernah hadir sampai dengan abad $6 \mathrm{SM}$ - pada era Zoroatisme dalam masyrakat Yahudi sebelum era Socrates dan di era pertengahan umat Yahudi dalam Pembuangan. Yahwisme awal sejatinya adalah agama keluarga yang popular di mana El dengan Yahweh selalu

31 Hermann Vorländer. 'Aspects of Popular Religion In The Old Testament', trans. Graham Harrison, in Popular Religion, Norbert Greinacher and Norbert Mette (eds.), Concilium 186, (Edinburgh, T \& T Clark, 1986), 63-70

${ }^{32}$ Norbert Lohfink, Theology of the Pentateuch, trans. Linda Maloney, (Edinburgh, T \& T Clark, 1994), 35-95. 
bertukar tempat dalam alam pemikiran orang Israel dari masa pendudukan sampai seterusnya. Mulai periode raja Yosia; sang raja menempatkan Yahweh sebagai Allah nasional tertinggi dengan membuang bentuk ilahi sesembahan lainnya; khususnya para ilah yang berada di bait Allah Yerusalem, dikeluarkan dan dihancurkan dalam gerakan reformasi keagamaan saat itu. Dengan ini Yahweh mengambil alih semua peran para Allah lainnya tanpa saingan.

\subsection{Keluaran 6:2-3}

Salah satu kesulitan besar untuk menentukan Allah para Patriak terletak pada teks Keluaran 6:2-3 yang banyak diperdebatkan. Terkesan penulis teks ini tidak menulis satu berita yang mengasumsikan para Patriak memiliki pengetahuan tentang Yahweh sekaligus memperlihatkan bukti Allah pernah memberikan pernyataan dengan nama Yahweh kepada mereka. Pertanyaan yang muncul adalah mengapa Yahweh tidak dikenal para Patriak padahal dalam kitab Kejadian nama tersebut digunakan secara bebas?

Keluaran 6:3 berbunyi "Selanjutnya berfirmanlah Allah

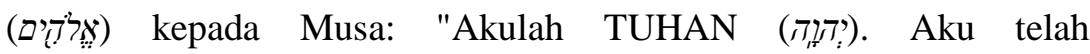
menampakkan diri kepada Abraham, Ishak dan Yakub sebagai Allah

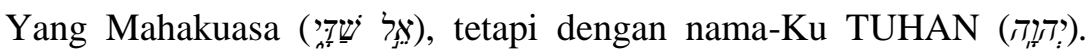
Aku belum menyatakan diri kepada mereka. Pembacaan awal teks ini memperihatkan para Patriak tidak memiliki kesamaan persepsi dengan Israel Keluaran Mesir mengenai Yahweh. Teks ini semakin menjadi sulit dipahami ketika dihubungkan dengan teks-teks lain dalam kitab Kejadian; seperti Kejadian 15:1-7, di mana Allah menampakkan dirinya kepada Abraham sebagai Yahweh yang membawa dirinya keluar dari Ur. Jika bukan Yahweh, siapa yang disembah Abraham saat itu? Kesulitan mencapai puncaknya ketika melihat teks Keluaran 3:13-15 sebagai berikut: "Lalu Musa berkata kepada Allah: "Tetapi apabila aku mendapatkan (datang kepada) orang Israel dan berkata kepada mereka: Allah nenek moyangmu telah mengutus aku 
kepadamu, dan mereka bertanya kepadaku: bagaimana (apakah namanya) tentang nama-Nya?--apakah yang harus kujawab kepada mereka?" Firman Allah kepada Musa: "AKU ADALAH AKU." Lagi firman-Nya: "Beginilah kaukatakan kepada orang Israel itu: AKULAH AKU telah mengutus aku kepadamu." Selanjutnya berfirmanlah Allah kepada Musa: "Beginilah kaukatakan kepada orang Israel: TUHAN, Allah nenek moyangmu, Allah Abraham, Allah Ishak dan Allah Yakub, telah mengutus aku kepadamu: itulah nama$\mathrm{Ku}$ untuk selama-lamanya dan itulah sebutan-Ku turun-temurun (dalam kurung tambahan penulis)." Dalam gambaran yang berhubungan dengan teks di atas kita melihat Musa sedang berada di gunung Horeb (Kel.3:1), sementara dalam pasal 6:3, ia dinyatakan berada di Mesir (Kel.5:1). Semua pasal ini berbicara mengenai panggilan Tuhan kepada Musa sekaligus menandai munculnya istilah tetragrammaton ${ }^{33}$ untuk pertama kali.

Dalam pendekatan dokumenteri hipotesis, Keluaran 6:3 merupakan sumber yang berasal dari kepenulisan Priest, sedangkan istilah Yahweh yang banyak ditemukan dalam kitab Kejadian (kecuali Kej.17: dan 21:1b), umumnya dihubungkan dengan kepenulisan Yahwis. Ketidaksesuaian antara Yahwis dan Priest akan muncul ketika teks; seperti Keluaran 3:13-15 dijadikan materi telaah. Musa sedang berada di gunung Horeb dalam pasal ini (Kel.3:1), sementara dalam pasal 6:3 ia berada di Mesir (Kel.5:1). Kelihatannya sumber Priest memiliki keakuratan data lebih tinggi tentang asal-mula

33 Istilah Tetragrammaton berasal dari bahasa Yunani $\tau \varepsilon \tau \rho \alpha \gamma \rho \alpha ́$ ́ $\mu \alpha \tau o v$, yang artinya " kata yang memiliki 4 huruf" yang merujuk pada nama Allah Israel YHWH yang dipergunakan dalam Kitab Ibrani. Ada beberapa ketidaksepakatan di antara para sarjana dan praktisi Yahudi serta Kristen mengenai nama Tetragrammaton ini; khususnya dalam tiga hal: Pertama: arti dari nama itu dan hubungannya dengan Kanaan; kedua, asalmula vocalnya; ketiga, apakah nama itu seharusnya dilihat sebagai nama sejarah, atau dapat dipergunakan saat ini. 
kemunculan Yahweh dibandingkan kepenulisan Yahwis yang terlihat lebih berusaha membuat penyembahan Yahweh seolah-olah telah hadir sejak permulaan jaman. Sedangkan sumber Elohis dalam Keluaran 3 ini berusaha menunjukkan betapa pentingnya gunung Sinai dengan menempatkan Musa di sana ketika ia berjumpa dengan Yahweh. Akan tetapi, jika kita melihat catatan Kejadian 4:26b; 15:17, Keluaran 3:13-15 dan pasal 6:3, apakah akan bermuara pada kesimpulan bahwa ketiga narasi tersebut berasal dari sumber berbeda? Terutama mengenai latar belakang sejarah Keluaran dalam tatanan dunia Timur Tengah Kuno, serta teks dan sintaks bahasa Ibrani dalam Keluaran 6:3 dan siknifikansi teologis dari pasal ini secara keseluruhan? Keluaran 3:13 memberikan indikasi bahwa Musa tidak mengenal nama Yahweh sebelum Yahweh memperkenalkan dirinya. Bahasa yang dipergunakan dalam Ulangan 6:3 mengandaikan belum ada pengetahuan akan nama Yahweh itu sendiri.

Beberapa ahli mencoba membangun jembatan untuk menghubungkan pasal-pasal yang bertolak-belakang tersebut. Jeffrey Cohen berargumen: Shadday dalam Keluaran 6:3 merupakan kombinasi dari dua kata yaitu: shad "dia perempuan" yang berarti sosok yang menyediakan dan istilah dai "mencukupkan." ${ }^{34}$ Dari etimologi ini Cohen melihat Allah telah menyatakan dirinya sebagai Allah yang menyediakan segala kebutuhan tepat pada waktunya. Dalam kasus para Patriak, Allah menyediakan segala yang mereka butuhkan, sedangkan dengan Musa, Allah yang sama mengadakan ikatan perjanjian. Dengan ini Cohen menyatakan bahwa Allah menyatakan dirinya hanya secara khusus dari karakternya kepada Patriak yang dikenal dengan nama El Shadday. Bagi Cohen, Allah menggunakan nama el shadday dalam penyataan dirinya kepada Musa berdasarkan pada sosok Musa yang merupakan pembawa obor yang pernah dipegang oleh para Patriak sebelumnya dalam upaya terus

${ }^{34}$ Jeffrey M. Cohen, How God Introduced Himself to the Patriarch, JBQ 37, No. 2 (2009), 119-120 
membawa janji-janji yang pernah diucapkan dahulu kepada Abraham. Musa menjadi orang yang terus membawa penyataan El Shadday yang di dalamnya termasuk semua unsur penyediaan dan janjinya. Bagi Cohen, bentuk niphal (ִָדָע (mengetahui) dalam ayat 3 mengindikasikan bahwa Allah membuat namanya diketahui oleh para Patriak, namun tidak dalam formula ikatan perjanjian yang melekat pada Yahweh Musa.

Argumentasi berbeda diajukan oleh Nahum Sarna. Menggunakan pendekatan serupa dengan Cohen, Sarna berargumen yang dimaksud Yahweh tidak menyatakan dirinya sebagai Yahweh kepada para Patriak adalah "para Patriak tidak memiliki pengalaman kuasa yang dihubungkan dengan Yahweh." Ia tidak menyatakan dirinya kepada mereka dalam "karakternya," selain memenuhi janjinya kepada Abraham. Menurut Sarna, istilah merupakan istilah umum yang dipakai raja-raja dunia Timur Tengah Kuno untuk menyebut dirinya yang sudah pasti telah diketahui. Jadi, jika nama Yahweh tidak dikenal di Israel, maka semua perkataan Yahweh akan menjadi sia-sia. Untuk itu, Allah menggunakan nama yang sudah dikenal Israel; bahkan oleh para pendahulunya untuk menyatakan kembali penyediaan yang Allah lakukan - yang kali ini ditambah dengan ikatan perjanjian. ${ }^{35}$

Menurut W.J. Martin, kalimat Tuhan tidak menyatakan dirinya sebagai Yahweh kepada para Patriak sebaiknya dilihat sebagai bentuk retorika negatif. Allah sedang berkata kepada Musa bahwa Patriak mengenal namanya sekaligus mereka tidak mengalami pengalaman penuh dengan ikatan perjanjian yang menempel pada Yahweh karena pemenuhan janji belum selesai. Lebih jauh Martin berargumen: para Patriak mengalami kesetiaan Yahweh dalam diri El Shadday yang kuat dan konsisten. Mereka percaya kepada Yahweh dalam diri El Olam, juga mereka mengalami hubungan mesra dengan

35 Nahum Sarna, The JPS Torah Commentary, (Philadephia: The Jewish Publication Society, 1991), 31-32 
Yahweh yang berdiam bersama mereka dalam diri El Betel. Memang ada beberapa epitet yang dipinjam dari Kanaan untuk keperluan tertentu, namun hal ini bukan berarti Yahweh tidak mereka kenal. ${ }^{36}$

Menurut Douglas J. Baker, jawaban Yahweh kepada Musa dalam Keluaran 3:12 'Aku akan beserta engkau,' sejajar dengan pernyataan umum Allah kepada para Patriak yang berhubungan dengan 'kedekatan' kepada sang ilah (Kej. 26:3, 24; 28:15.20; 31:3). Selanjutnya, kalimat dalam Keluaran 3:13 ' ...Allah nenek moyangmu telah mengutus aku kepadamu...' apakah memberikan bukti bahwa orang Israel telah mengenal nama Allah? Bagi Baker, pertanyaan Musa dalam ayat 13 sebatas keinginan untuk mempelajari atribut Allah; di mana ia tidak berusaha untuk mengetahui apakah nama Allah telah diketahui dan digunakan sebelum peristiwa Keluaran 3 tersebut (argumen ini tentu saja menempatkan pada posisi nama Allah telah dikenal sebelumnya, sekaligus belum dikenal). Kemungkinan poin pertama menjelaskan mengapa Musa mengajukan pertanyaan yang ia sendiri sudah tahu jawbannya. Kedua, menunjukkan pertanyaan hipotetikal yang mungkin bisa berarti sesuatu apabila nama Yahweh merupakan sesuatu yang 'baru'; untuk apa Israel mengajukan pertanyaan jika mereka tidak tahu jawabannya? Berdasarkan hipotetikal di atas, Baker berkesimpulan: tidak penting nama Yahweh telah diketahui atau sebaliknya saat itu, tetapi yang utama adalah menyatakannya. ${ }^{37}$

Jawaban Yahweh dalam Keluaran 3:14, kelihatannya memiliki kesulitan lebih dari pertanyaan Musa di ayat sebelumnya. Dalam membahas frasa 'aku adalah aku,' pendekatan terbaik yang harus dilakukan untuk mendapat jawaban terbaik menurut Baker adalah mengikuti konstruksi idem per idem yang dibangun G.S.

${ }^{36}$ W.J. Martin, Stylistic Criteria and the Analysis of the Pantateuch, (London: Tyndale, 2003), 18-19.

${ }^{37}$ Douglas J. Baker. El ELohe Esrael?An Inquary Into The Alleged Background of Early Israelite Religion, (Deerfield, Illinois, 2010), 21-44 
Ogden. "Idem per idem adalah kata kerja dalam klausa prinsipal yang diulang dalam klausa subbordinasinya, kemudian ditautkan oleh satu bentuk yang disebut relative pronoun." Contoh yang bisa dipergunakan adalah teks Keluaran 33:19; teks yang berisi narasi percakapan antara Allah dengan Musa 'aku akan berbelas kasih kepada siapa aku berbelas kasih, dan aku akan menunjukkan sayangku kepada siapa aku menunjukkan sayangku.' Percakapan ini menurut Baker memiliki kesejajaran dengan pernyataan dalam Keluaran 3:14. Sehingga teks ini dapat diterjemahkan dengan "I am being' or I am the Is-ing One,' yaitu 'the One Who Always Is.' Pernyataan ini tentunya menekankan pada ide kehadiran atau tindakan saat itu (present action). Pada akhirnya ehye aser ehye mungkin tidak dibaca dalam pengertian literal, melainkan dalam konteks sebagai sastra puisi (Kej. 17:5; 25:26; 27:36 dan Kel.2:10). Untuk itu, Baker menyimpulkan pertanyaan Musa dalam ayat 13 bukan merupakan asumsi pengetahuan awal dari Tetragrammaton; bahkan jawaban Allah dalam ayat 14 juga bukan merupakan penyingkapan dari kualitas nama ilahinya, selain bentuk tautologi ${ }^{38}$ yang mungkin merujuk pada pernyatan ayat 12 . Jawaban Allah dalam ayat 14 tidak memberikan kontribusi apapun bagi kejelasan isu di atas sebab secara teknis jawaban tersebut bukanlah merujuk pada namanya, melainkan suatu percakapan yang akan berakhir dengan jawaban idem per idem dan akan berujung pada apa yang sebelumnya telah Ia informasikan kepada Musa (Aku akan beserta Engkau). Kesimpulan prematur yang dapat disusun berdasarkan ayat 15 mengenai orang Israel yang 'akan mengetahui sang Allah melalui namanya Yahweh,' hanya bisa dilakukan dengan asumsi mereka belum mengetahui atau belum memiliki pengetahuan akan nama tersebut. Jika mereka tidak

${ }^{38}$ Tautologi adalah majas berupa pengulangan gagasan, pernyataan, atau kata secara berlebihan dan tidak perlu. Majas ini memiliki kemiripan dengan pleonasme karena sama-sama menambahkan kata atau keterangan yang tidak diperlukan. 
berespon, maka hal ini adalah bentuk penyataan, tetapi jika mereka sudah mengetahui sebelumnya, maka secara sederhana hal tersebut merupakan indikasi nama ini dipergunakan untuk generasi yang akan datang, karena akan terus konsisten dengan karakternya. ${ }^{39}$

Keluaran pasal 3 menurut Baker tidak memberikan jaminan jawaban apakah nama Yahweh telah diketahui oleh Israel sebelum era Musa. Untuk itu, ia memasukkan teks Keluaran 6 sebagai upaya jelajah pengetahuan nama Yahweh yang digunakan Israel pra Musa; sekaligus sebagai pasal yang menurut Baker berhubungan dengan isu utama nama ilahi yang unik dan antik itu sendiri. Untuk mengetahuinya harus dimulai dari kegagalan Musa dan Harun di hadapan Firaun dalam melepaskan Israel. Alih-alih dilepaskan, orang Israel justru semakin disiksa. Dalam konteks inilah Musa kembali ke hadapan Yahweh melakukan komplain, menuduh Yahweh gagal menjalankan janjinya. Yahweh kemudian merespon dengan mengumumkan kembali rencananya untuk membebaskan umatnya. Jawaban Yahweh dimulai dengan kalimat 'Aku telah menampakkan diriku kepada Abraham, Ishak dan Yakub...tetapi dengan namaku Tuhan Aku belum menyatakan diri' (Kel.6:2-3). Dalam pasal ini nampaknya Abraham, Ishak dan Yakub tidak mengetahui Tuhan dengan nama Yahweh, melainkan dengan nama 'él Śadday. Sebab, nama Yahweh pertama kali dinyatakan hanya kepada Musa saja. ${ }^{40}$

Baker tidak menyangkal sumber berbeda mungkin bekerja di belakang teks Keluaran 3 dan 6, atau dalam teks Kejadian pada umumnya, sebab tidak ada bentuk penyangkalan dari teks itu sendiri - seperti yang terekam dalam Kej.5:1; Bil. 21:14 dan 33:2. Akan tetapi, Baker menolak menetapkan kesulitan dalam menjelaskan nama Yahweh atau konflik dalam Keluaran 6:3 hanya berdasarkan

${ }^{39}$ Ibid., Douglas J. Baker, El ELohe Esrael? 21-44; Lihat juga G.S. Ogden, Idem Per Idem: Its Use And Meaning, JSOT, Vol 17, Issue 53 (1992). ${ }^{40}$ Ibid., 45-53 
pada alasan multi sumber teks seperti di atas; sekaligus ia menolak menggunakan penggunaan kritik sumber dalam menginterpretasi Keluaran pasal 6. Menggunakan pernyataan Whybray, Baker menulis: konsistensi merupakan hallmark dari beragam dokumen, inkonsistensi merupakan hallmark dari para redaktur. ${ }^{41}$

Bagi Baker, Keluaran 6:3 merupakan bentuk pernyataan di mana para Patriak belum mengerti akan nama Yahweh. Namun, para Patriak sudah mengetahui siapa sesungguhnya Yahweh, hanya saja mereka belum memiliki pengalaman seperti yang dimiliki Israel di kemudian hari. Allah tidak mungkin bergerak dalam cara yang tidak diketahui dalam sejarah, apalagi ketika Ia mengajukan nama baru yang kemudian menimbulkan dikotomi palsu antara keduanya? Tentu akan sulit dipahami. Nama baru benar-benar telah diberikan kepada Musa dan Israel dan pada saat bersamaan telah ada 'pengetahuan' terhadap Allah dalam konsep teologis yang juga harus diapresiasi. Ini bukan skenario 'yang mana/atau' melainkan 'keduanya/dan.' Pertanyaan apakah para Patriak telah mengenal nama Yahweh atau belum bagi Baker merupakan langkah penting untuk menentukan apakah narasi Kejadian dan Keluaran dapat dipergunakan sebagai bukti adanya penyembahan 'él di Israel; sekaligus sebagai refleksi para Patriak telah memiliki pengetahuan mengenai identitas Allah mereka. Implisit atau eksplisit nama Yahweh telah diberikan kepada Musa, sehingga dapat disimpulkan pengetahuan akan Yahweh telah tersebar pada awal sejarah ini. Jadi, akan sangat sulit untuk berkata ketidakhadiran teoporik nama Yahweh pada periode awal tersebut di Israel. Keluaran 3 memang tidak memberikan data lengkap atas isu ini, sedangkan Keluaran 6 sebaliknya. Jika kedua pasal ini dihubungkan, maka pasal 3 kelihatannya berisi pewahyuan dari nama keilahaian - sekaligus pasal 6 menyatakan nama tersebut.

Nama Yahweh baru dinyatakan kepada Musa, namun Ia telah dikenal dengan nama lain sebelum Israel; yaitu 'êl. Kehadiran

${ }^{41}$ Ibid., Douglas J. Baker, El ELohe Esrael? 45-53 
nama ilahi 'êl dalam kitab Kejadian menurut Baker lebih baik dijelaskan dalam retrojeksi teologis dari para penulis Yahwistik, mengingat Israel pra-Musa tidak menggunakan nama Yahweh untuk menunjuk Allah mereka. Alkitab menggunakan banyak ungkapan untuk menunjukkan cara mana Israel menggunakan nama Yahweh. Salah satu penggunaan tersebut adalah istilah אֵ, yang terlihat banyak digunakan dalam kitab Kejadian; baik dalam penggunaan nama personal maupun dalam penggunaan varian 'él yang ditujukan bagi karakternya. Istilah אִ sepertinya banyak digunakan orang Israel sebelum era Musa untuk menyatakan siapa Allah sesembahannya; seperti terelam dalam konteks Keluaran $6 .{ }^{42}$

Sepanjang catatan teks-teks Perjanjian Lama, HB menggunakan kata 'ēl untuk merujuk kepada Yahweh dan 'èl Allah Kanaan. Gambaran Perjanjian Lama yang multi tafsir tersebut menghasilkan perbedaan terjemahan dari para penafsir Perjanjian Lama. Mark S. Smith, Thomas L. Thompson dan Rainer Albertz mempertahankan ide 'êl dan Yahweh sebagai dua ilah berbeda yang kemudian berfusi menjadi Yahweh pada periode tertentu di Israel; khususnya dalam berita orang-orang era Pembuangan dan pascaPembuangan.

Sedangkan F.M. Cross, Heisser atau Patrick D. Miller, memiliki argumen berbeda. Menurut kelompok kedua, pemisahan figur 'èl dan Yahweh tidak mungkin terjadi semenjak keduanya merupakan ilah identik. Seperti yang sudah dijelaskan penulis di Bab II, narasi Patriak menempatkan 'êl sebagai sebutan atau julukan umum untuk menyebut Allah Israel dan Kanaan yang menduduki tempat tertinggi di sidang ilahinya; sementara Yahweh dan Ba'al berkompetisi untuk merebut kedudukan 'ēl - yang pada akhirnya Yahweh menggantikan kedudukan sang kepala panteon.

${ }^{42}$ Ibid., Douglas J. Baker, El ELohe Esrael, 55-64 
Yahweh yang menyatakan dirinya kepada Musa sebagai Allah Patriak dan menghubungkan epitet El kepada Yahweh dalam Keluaran 6.2-3, memberikan gambaran bahwa pasal ini menggunakan beberapa epitet yang biasa merujuk kepada 'ēl dan ditujukan secara khusus kepada Yahweh. Menurut Mark S. Smith, pasal ini membuktikan Yahweh tidak dikenal oleh para Patriak, ${ }^{43}$ sebaliknya mereka dikenal sebagai penyembah 'ēl. Narasi Patriakal tidak pernah membedakan catatan mengenai hadirnya nama atau narasi Yahwistik, melainkan para editor Pentatuk yang memasukkan nama Yahweh dalam narasi Patriak walaupun mereka tidak mengenal Yahweh.

Berbeda dengan Smith, Patrick D. Miller melihat Yahweh memiliki hubungan dengan El dalam suatu waktu tertentu namun hubungan itu putus di era tertentu. Menurut Miller, para Patriak menggunakan eiptet umum untuk menggambarkan El dengan sebutan el olam dan el shadday atau el sang pencipta dalam hubungannya sebagai Allah Israel. Dalam hal ini nama Yahweh kemungkinan besar awalnya merupakan nama kultis dari El, namun dalam era terkemudian kultus Yahweh memisahkan diri dari penyembahan El; menjadi penyembahan terhadap Yahweh semata (kemungkinan terjadi pada era reformasi Yosia). ${ }^{44}$ Untuk itu, Miller yakin pada mulanya Yahweh merupakan gambar (figur) El seperti yang diindikasikan oleh Keluaran 6.2-3, namun tidak seperti yang digambarkan oleh teks tersebut bahwa Yahweh diidentikkan dengan El-Shadday. ${ }^{45}$

Serupa dengan Miller, F.M. Cross melihat Keluaran 6.2-3 merupakan contoh jelas pemisahan antara agama Patriak dengan agama Musa. Dalam Keluaran pasal 3, 4 dan 6, berulangkali kita

43 Mark S. Smith, The Origin of Biblical Monotheism, (Oxford: Oxford University Press, 2001), 141

44 Patrick D. Miller, The Religion of Ancient Israel, (lousville: Westminster John Knox Press, 2000), 24-25

${ }^{45}$ Ibid. 
melihat frasa "Allah Bapa Leluhur" muncul. Sedangkan Keluaran 6:3, Yahweh dinyatakan dengan jelas, namun nama Yahweh tersebut belum dinyatakan kepada para leluhur. Satu hal yang pasti adalah Allah Patriak ini menurut Cross berbeda dengan El yang disembah orang Kanaan. Perbedaan yang diajukan Cross kelihatannya untuk mengantisipasi kultus Yahweh yang nantinya akan digabungkan dengan kultus El oleh Cross. Apabila asumsi ini dipergunakan, maka, argumen Cross mengenai El dan Yahweh sebagai ilah identik berpisah kemudian bersatu kembali, dapat dibuktikan. Untuk itu Cross pada akhirnya akan sampai pada kesimpulan bahwa sosok Yahweh asalinya merupakan nama kultik dari El; sekaligus boleh disimpulkan bahwa Yahweh merupakan epitet dari El yang adalah ilah utama di Midian dan Keni. Itulah sebabnya kita melihat antara kultus Yahweh dengan kultus El (kemudian menjadi El Kanaan) tidak pernah berselisih di Kanaan; bahkan dalam kitab Perjanjian Lama, tidak terlihat adanya ketegangan atau polemik antara El dengan Yahweh. Kesamaan atau identiknya figur El dengan Yahweh sejak semula dalam teori Cross di atas pada akhirnya akan membenarkan klaim Keluaran 6:3 bahwa Allah yang diperkenalkan Musa adalah Yahweh yang merupakan Allah yang dulunya dikenal oleh para Patriak; Abraham, Ishak dan Yakub, yang dikenal dengan el elohe Abraham, Pahad Yitzak dan Abir Yakub - walaupun ironisnya Cross terlihat sangat menekankan perbedaan nyata antara El dan Yahweh berdasarkan beberapa catatan Perjanjian Lama; di antaranya catatan Yeh. 28:2 di mana ia menggunakan El yang berasal dari matrix Kanaan sebagai sesembahan Israel. Selain itu, Hak. 9:46 menurut Cross membedakan dengan jelas antara El dengan Yahweh dalam penggunaan istilah El-Berit yang dipercaya merupakan penyebutan epitet umum bagi El. ${ }^{46}$ Ketika El pada akhirnya tersingkir dari tempat utamanya dalam konstelasi Sidang Ilahi - Allah Yahweh kemudian

${ }^{46}$ Frank M. Cross, Canaanite Myth and Hebrew Epic, (Cambridge, Massachussets: Harvard University Press, 1973), 44-45 
melakukan pemisahan dengan EL (epitet dan atributnya). Namun demikian, kita tetap melihat sepanjang sejarah agama Israel variasi dari nama El terus dipergunakan dan diterima sebagai titel yang ditujukan kepada Yahweh. ${ }^{47}$

Berbeda dengan Miller dan Cross, Albertz yakin penggabungan (fusi) antara El dan Yahweh terjadi setelah peristiwa Keluaran Mesir, dilanjutkan pada periode saat Israel berada di Kanaan. Lebih lanjut Rainer Albertz melihat masyarakat Kanaan Penyembah El menerima masuknya Israel Keluaran Mesir dengan Yahwehnya - yang dikemudian hari mayoritas masyarakat (Israel dan Kanaan) memilih Yahweh sebagai ilah sesembahan utama mereka. ${ }^{48}$ Posisi Yahweh yang naik menjadi Allah utama di Kanaan menurut Albertz didorong oleh nuansa 'pembebasan' yang dimiliki Yahweh yang cocok bagi kaum proletar Kanaan dan Israel yang mencoba mencari identitas diri setelah mereka sama-sama terbebas dari Mesir saat itu. Oleh karena itu, semua elemen El difusikan ke dalam Yahweh - Allah maha kuat Israel yang telah dimulai sejak era para Hakim yang indikasinya terlihat dari nyanyian Debora. ${ }^{49}$

Para Patriak tidak pernah mengetahui Yahweh dengan nama ilahinya, melainkan mereka merupakan kaum penyembah El. Narasi Patriakal yang memuat ide penyatuan El dan Yahweh yang berasal dari kepenulisan setelah pembuangan tidak dapat dipergunakan sebagai sumber valid hubungan El dengan Yahweh dengan alasan faktor editing yang telah terjadi. El merupakan Allah utama para Patriak (kepala panteon)yang kemudian perlahan menghilang dalam sistem panteon Kanaan dan Israel, digantikan oleh

${ }^{47}$ Ibid., Cross, Canaanite Myth and Hebrew Epic,44-45

${ }^{48}$ Rainer Alberz, From the Beginnigs to the End of the Monarchy, Vol. 1 of A History of Israelite Religion in the Old Testament Period (Lousivilee: Westminster John Knox Press, 1994), 77-80

49 Ibid. 
Yahweh yang adalah ilah level dua (Smith dan Handy), naik mengambil posisi, epitet dan apelatif El sebagai Allah utama Israel.

\subsection{Ruang Lingkup Keluaran 6:2-8}

Dalam narasi Keluaran 6:2-8, terlihat Musa dideskripsikan datang kepada Firaun setelah menerima nama Yahweh di Sinai untuk mendeklarasikan apa yang diperintahkanNya. Jawaban Firaun dalam Keluaran 5:2:

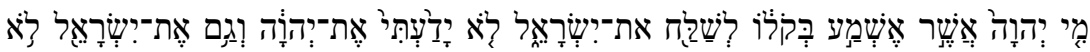

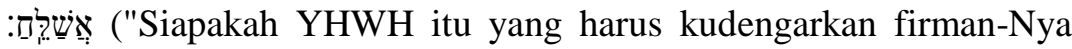
untuk membiarkan orang Israel pergi? Aku tidak kenal YHWH itu dan tidak juga aku akan membiarkan orang Israel pergi)." Bentuk pertanyaan di sini kelihatannya tidak bisa diterjemahkan hurufia, sebab Firaun sedang tidak bertanya mengenai identitas Allah Musa dan Harun - Ia sepertinya sedang menekankan mengenai Yahweh yang tidak siknifikan di matanya. Musa dalam narasi itu digambarkan kembali kepada Yahweh dan berpikir bahwa Yahweh telah gagal membebaskan umatnya dengan meragukan penugasannya yang

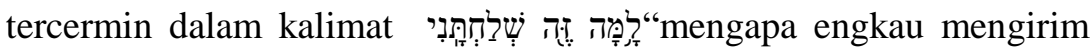
aku"? (Kel. 5:22). Respons pertama Yahweh muncul dalam pasal 6:1 "tangan yang kuat" sebagai bentuk simbolis (alusi) dalam Keluaran 3:19 "Tetapi Aku tahu, bahwa raja Mesir tidak akan membiarkan kamu pergi, kecuali dipaksa oleh tangan yang kuat." Dengan ini terlihat teks Keluaran 6:1 menyatakan secara umum tindakan simbolis Yahweh, sedangkan Keluran 6: 2-8 menjelaskan 'bagaimana dan mengapa' dia akan bertindak.

Teriakan Israel dari Mesir mendorong Yahweh untuk

melakukan tindakan pelepasan. Dalam Keluaran 3:16-17 Yahweh berkata kepada Musa bahwa Ia akan melakukan tindakan penyelamatan yang berhubungan dengan ikatan perjanjiannya. Dua

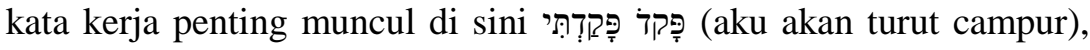
LAI: "aku mengindahkan" dan אְִּלָה (aku akan membawa), LAI: "Aku 
akan menuntun." Kedua kata kerja ini merupakan inti dari "tindakan" Yahweh terhadap Mesir yang dinyatakan dalam bentuk 10 Tulah, yang hasilnya membawa Israel ke Tanah Perjanjian. Kedua kata kerja ini kelihatannya menjadi bentuk antisipasi intervensi Yahweh di kemudian hari. Keluaran 3:7-10 berhubungan dengan teks Keluaran 2:23-25 yang berisi teriakan Israel - serta maksud Yahweh untuk melepaskan mereka; bahkan dalam Keluaran 2:24 menggambarkan bagaimana Yahweh ingat akan PerjanjianNya dan dalam Keluaran 3:8 Dia digambarkan turun untuk menyelamatkan mereka. Semua gambaran ini dihubungkan dengan Kejadian 15 yang menunjukkan adanya kesatuan prediksi Yahweh dari era Patriak sampai dengan era Musa yang digambarkan dalam kitab Kejadian kemudian dinyatakan dalam kitab Keluaran. Jadi perkataan Yahweh dalam Keluaran 6:2-8 terlihat sebagai sejarah penebusan yang telah diprediksi sejak jaman Abraham. $^{50}$

Keluaran 6:2-8 merupakan sub unit dari satu unit besar yang terbentang dari Keluaran 5:22 sampai Keluaran 7:7, yang berisi protes Musa atas tindakan "berdiam" Yahweh, sekaligus teks pasal 6:2-8 ini merupakan perluasan respon awal Yahweh terhadap keraguan dan protes Musa dengan memberikan pernyataan definitif atas persoalan yang dihadapi Musa yang dilaporkan dalam pasal 6:9 "Lalu Musa mengatakan demikian kepada orang Israel, tetapi mereka tidak mendengarkan Musa karena mereka putus asa dan karena perbudakan yang berat itu."

\subsection{Genre Keluaran 6:2-8}

Dikarenakan sang nabi memberitakan peristiwa yang akan terjadi; di mana ia memberikan jaminan kepada para pendengarnya yang dalam tekanan, maka genre dari pasal ini dapat

50 Jonathan Magonet, The Bush that Never Burnt: Narrative Techniques in Exodus 3 and 6, The Heythrop Journal 16 (1975), 3111 
dikategorikan sebagai 'proklamasi keselamatan'. Menurut Joseph Wimmer, respon Yahweh terhadap keadaan darurat Israel di Mesir (Kel. 6:5-8), kesadaran diri Allah (ay.5c, 6b), janji Tuhan akan bertindak (ay.6c-7b) dan tujuan pelepasan (ay.7c, d), merupakan bentuk khusus dari elemen 'ikatan perjanjian' (ay.7a, b) yang menekankan pada keharusan untuk mematuhi ikatan perjanjian. ${ }^{51}$ Akan tetapi, mayoritas sarjana ANET melihat Keluaran 6:2-8 sebagai "narasi panggilan sekaligus ucapan ilahi" yang dapat dihubungkan dengan Keluaran 3:1-4:17. ${ }^{52}$ Klasifikasi ini sejajar dengan pendekatan Dokumenteri Hipotesis di mana Keluaran 3:1-4:17 dilaporkan oleh JE mengenai pemanggilan Musa, sedangkan Keluaran 6:2-7:7 merupakan berita Priest tentang pemanggilan Musa. Narasi 'panggilan' Priestly menekankan pada peranan Harun, sedangkan narasi non Priestly mengabaikan Harun. Namun demikian kedua teks tersebut pada akhirnya memuat berita mengenai perintah Yahweh kepada Musa (Kel. 3:10 dan 6:6,10) sekaligus berisi keberatan Musa terhadap perintah tersebut (Kel. 3:11; 4:10; 5:22-23; 6:12,30). ${ }^{53}$

\subsection{Analisis Literari Keluaran 6:2-8}

Struktur teks ini dapat diawali oleh ucapan ilahi yang ditujukan pada situasi Israel, yang dimulai dari para Patriak yang berkelana di Kanaan (ay.4) dan dilanjutkan dengan perbudakan Israel di Mesir (ay.5) yang mana tindakan Yahweh ternyata didorong oleh ikatan perjanjiannya (ay.3) yang pada akhirnya semua janji Yahweh

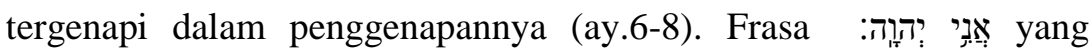
terdapat pada ayat 2 dan 8 merupakan permulaan dari lingkaran struktur yang di dalamnya termasuk para Patriak (ay. 3b,8c), tanah

51 Joseph F. Wimmer, Tradition Reinterpreted in Ex 6, 2-7:7, Augustinianum 7 (1967), 410-416

${ }^{52}$ Marthin Noth, Exodus, Trans. J.S. Bowden, OTL (London: SCM, 1962), 58

${ }^{53}$ Ibid., Marthin Noth, Exodus, 58-61 
Kanaan (ay.4b, 8a) dan kerja paksa Israel di Mesir (ay. 5b, 7d).

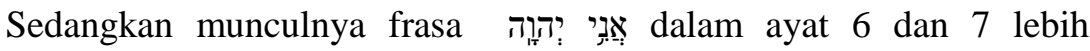
menunjuk pada tindakan pelepasan Yahweh dari perbudakan (ay.6c) kemudian diakhiri saat Ia menjadi Allah bagi Israel (ay.7), teks terakhir terlihat menciptakan struktur utama dari lingkaran terebut.

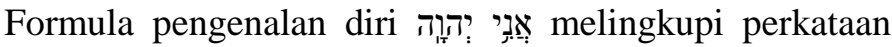
Yahweh sekaligus merujuk pada Tanah Perjanjian, serta para Patriak dan perbudakan di Mesir. Dengan ini, Yahweh terlihat menjadi subjek dari teks Keluaran 6:2-8 yang kemudian membangun semacam kesatuan retorika. Namun demikian, menurut penulis, perkataan Yahweh lebih mudah dibagi dalam dua unit kecil saja: teks Keluaran 6:2-5 yang berisi pesan Yahweh kepada Musa; sekaligus sebagai dasar kedatangannya untuk melakukan intervensi berdasarkan janji yang telah dicanangkan pada masa lalu, plus teks Keluaran 6:6-8 yang berisi perkataan Musa kepada Israel; yang juga berisi janji Yahweh yang akan bertindak karena ikatan perjanjianNya. Dengan ini kita melihat hadirnya identitas dan tindakan Yahweh sebagai gambaran sentral dari teks Keluaran 6:2-8 ini.

Tindakan Yahweh pada akhirnya dapat dikatakan hanya berdasarkan kepada ikatan perjanjian kepada para Patriak yang kemudian dijabarkan (dilanjutkan) dalam Musa. Bentuk inklusio dari istilah רִריתי dalam ayat 4 dan 5 menunjukkan Israel pada era Musa terikat dalam ikatan perjanjian dengan Abraham. Dengan mengatakan

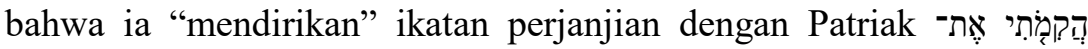
, dרִּרִתִ, dan bukan "membuat" ikatan perjanjian (כרת), Yahweh terindikasi melakukan penggenapan pada perjanjian yang telah ada sebelumnya. ${ }^{54}$ Hal ini memiliki arti: ketika Yahweh berkata ia "mengingat" perjanjianNya, Yahweh bukan saja berbicara ingatan akan perjanjian, melainkan 'bertindak' berdasarkan janji sebelumnya kepada para Patriak; dalam hal ini kepada Abraham.

54 Umberto Cassuto, A Commentary on the Book of Exodus, trans, Isael Abraham (Jerusalem: Magnes, 1967), 79 
Munculnya istilah וְٕ dalam ayat 4 dan 5 dapat dianggap sebagai kesimpulan hubungan Yahweh dengan Abraham, Ishak dan Yakub secara filologi; di mana Yahweh muncul dihadapan mereka sebagai Allah kesuburan - sekaligus וְג ini mendirikan ikatan perjanjian dengan Israel yang dilanjutkan dengan arti וِٕ yang berarti Ia telah mendengar teriakan mereka. ${ }^{55}$ Keluaran 6:2-5 membangun semacam jembatan untuk menghubungkan era Patriak dan Israel dengan Musa saat itu. Walaupun Yahweh tidak dikenal oleh Patriak, namun identitasnya sebagai Allah yang mengikat ikatan perjanjian dan yang memiliki jaminan akan selalu melakukan intervensi, tidak berubah.

Analisis yang agak berbeda namun memiliki argumentasi seperti di atas dilakukan oleh Thomas L. Thomson. ${ }^{56}$ Thomson melihat tradisi teks Keluaran 6 (juga pasal 3) sebagai hasil tradisi Elohis yang memainkan peran utama dalam Keluaran 3.13-15 Dalam teks-teks tersebut jelas terlihat ada keberlanjutan antara agama para Patriak dengan iman Yahwistik Israel di kemudian hari. Pada saat bersamaan teks tersebut juga menekankan adanya identifikasi antara agama Yahweh dengan agama para Patriak, sekaligus menutup kemungkinan agama Patriak dan agama Musa berasal dari dua strata berbeda apabila merujuk kepada formula penulisan teks Perjanjian Lama dari Periode Persia dan Helenistik yang diwarnai dengan kepentingan teologis para penulisnya.

Catatan Priestly dalam Keluaran 6.2-3 merujuk arah sejajar dengan Keluaran 3 ketika menyatakan: "Selanjutnya berfirmanlah Allah kepada Musa: "Akulah TUHAN. Aku telah menampakkan diri kepada Abraham, Ishak dan Yakub sebagai Allah Yang Mahakuasa ('ēl Shadday), tetapi dengan nama-Ku TUHAN Aku

55 T. Muraoka, Emphatic Words and Structures in Biblical Hebrew (Jerusalem: Magnes, 1985), 143-146

56 Thomas L. Thomson, How Yahweh Became God: Exodus 3 and 6 and the Heart of the Penteuch, JSOT, 68 (1995), 57-74 
belum menyatakan diri (LAI). Tradisi ini terlihat menggambarkan hadirnya keterhubungan antara agama kuno Patriak dengan era Yahwistik dalam bingkai penjelasan teologis; sekaligus menjadi latar belakang bagi terbitnya agama Yahwistik di kemudian hari. Apabila mengikuti hipotesis Albrecht Alt, maka 'èl yang disembah para Patriak di atas berbeda dengan 'èl yang disembah orang Kanaan yang terikat dengan kultus atau local numina tertentu di Kanaan. El para Patriak sebaliknya lebih terikat atau diidentikkan dengan para Patriak - kepala klan - tepatnya 'èl adalah Allah keluarga. Jika diperhatikan dengan lebih detil, terlihat hadirnya inkonsistensi antara kedua pasal Keluaran di atas; khsusnya sumber Elohis dan Priest. Solusi tidak mungkin diambil dengan menghilangkan nuansa dokumentari di atas. Solusi yang dapat ditawarkan adalah menjadikan bentuk akhir dari teks yang ada sebagai inti atau pusat dari kritik yang harus dilakukan dalam hal ini kritik literari dijadikan landasan interpretasi atas kedua narasi di atas.

Menurut penulis, persoalan awal yang harus mendapatkan perhatian adalah karakter ilahi yang ada dalam kedua narasi tersebut. Dalam Keluaran pasal 3 kita melihat Musa yang

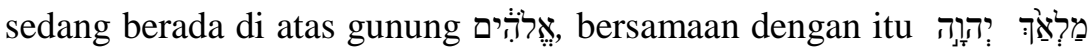
muncul di hadapan Musa. Memasuki beberapa ayat kemudian dalam pasal ini kita menemukan karakter Allah dalam narasi pasti akan


pasal 14 kedua istilah tersebut kelihatan melebur dalam satu sebutan yaitu: יהוזה: dalam bentuk tiang api dan tiang awan. Kembali kepada Keluaran pasal 3, identifikasi serupa dapat dilakukan pada bagian ini

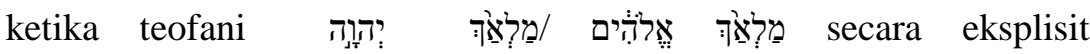
mengidentifikasikan dirinya sebagai אֶלדָים para Patriak; Abraham, Ishak dan Yakub. Namun ada varian menarik dalam kitab Keluaran


sintatik melakukan pembedaan antara kata benda אֶלהּים dengan nama יהניה 
Referensi yang muncul dalam kaitannya dengan Abraham, Ishak dan Yakub dalam Keluaran 3, dapat kita hubungkan dengan Kejadian 16 dan 21 yang memiliki pola narasi identik. Dalam


sekaligus sinonim dengan istilah'él rō'̂̂ di Berlahai Roi (Kej.16:13). Dalam teks ini, istilah'ēl rō'̂̀ yang muncul dalam dialog kitab Kejadian di atas dihubungkan dengan Yahweh yang muncul melalui mulut Ismail dan Hagar. Berdasarkan argumentasi di atas, kelihatannya pendekatan Dokumenteri Hipotesis tidak akan menolong dalam memahami teks ini dikarenakan motif pemberian nama kepada anak Hagar merupakan bagian integral sekaligus bagian penting dari ide 'teofani keselamatan' yang mencetak arti dari nama Ismail sebagai "el yang mendengar" dengan aetiologi (sebab/penyebab) 'Yahweh telah mendengar.' Variasi dengan kesamaan model di atas juga ditemukan dalam teks Kejadian 21:17 “...sebab Allah telah mendengar suara anak itu dari tempat ia terbaring," dalam hal ini kita melihat atau menemukan frasa Elohim telah mendengar teriakan Hagar dan Ismail. Sedangkan cerita dalam Kejadian 21 yang merupakan pemenuhan (janji) Yahweh dari teks Kejadian 18 kepada Sarah; di mana janji tersebut dilaksanakan oleh pasa pasal 21. Dalam bagian akhir teks tersebut (ay.33) kita melihat Abraham memanggil nama יהוּנו אֶֶּלהים dalam narasi korban Ishak pada pasal selanjutnya; di mana frasa

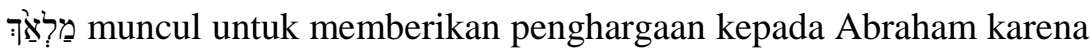
telah hormat dan tunduk kepada אֶֶ,.

Cerita teofani dalam Keluaran 3 dan 6 dalam kacamata literari merupakan episode cerita di mana nama ilahi ditemukan saling berhubungan secara koheren dalam plotnya masing-masing dan bukan merupakan gambaran kompleks dari beragam sumber tradisi; sekaligus tidak bermain dalam tataran pembagian karakter keilahian

${ }^{57}$ Ibid., Thomson, How Yahweh Became God, 57-76 
antara kedua teks tersebut. Itulah sebabnya identifikasi di atas kelihatannya menebarkan motif umum; yaitu penamaan dan identifikasi atas salah satu tradisi keilahian lama yang disebut atau dikenal dengan sebutan אֶלה:. Tidak perduli apakah ilah tradisional yang dimaksud di sini merupakan ilah yang 'nyata' hadir pada masa lalu, seperti yahweh, atau ia sebatas Allah yang hadir dalam sejarah,

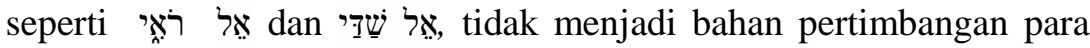
penulis tradisi tersebut; dalam hal ini para penulis dari era Persia atau Helenistik yang membuat teks-teks tersebut. Namun yang terutama adalah nuansa "identifikasi" (identify) yang sangat relevan ketika keduanya memberikan tanda untuk setiap cerita dengan perspektif yang unik - terkadang mencengangkan. ${ }^{58}$

Argumentasi ini menurut penulis memperlihatkan penggunaan langsung dari bentuk posesif pronoun yang dihubungkan dengan beberapa protagonis berbeda dalam kedua narasi tersebut. Tujuan tematik dan ideologis yang merupakan motif utama yang terdapat dalam cerita Keluaran 3 dan 6 jelas menjadi semacam jembatan penghubung ke dalam bentuk narasi umum (umum dimengerti pembaca saat itu). Hal ini dapat terlihat dari formulasi yang jelas dari motif perkataan אֶלהּים dalam keluaran 6:7 "Aku akan

58 Thomas L. Thompson merupakan sejarawan minimalis yang percaya bahwa kita tidak mungkin melakukan rekosntruksi sejarah prapembuangan atau perkembangan agama Israel melalui teks-teks Perjanjian Lama yang ada dikarenakan literatur tersebut merupakan karya fiksional dari orang-orang pasca-Pembuangan (walaupun ia percaya ada catatan lebih tua yang berasal dari era Yosia dalam teks-teks tersebut). Bagi Thompson, Israel awal sangat politeistik, bahkan Henoteistik. Awal Monoteisme mungkin berasal dari ide para nabi klasik yang kemudian diumumkan secara luas dalam reformasi Yosia. Pengaruh yang besar dunia Pembuangan atas Israel memaksa mereka melakukan sintesa keagamaan dengan bangsa Persia. Ilah utama Siria - Elohe Shamayim diidentifikasi/ dihubungkan dengan Yahweh yang muncul dari kultus Israel di Samaria dan Teman. Pada akhirnya Monoteisme Israel merupakan perkembangan lengkap dari era pascaPembuangan dan oleh karena itu tidak berhubungan dengan era sebelum Pembuangan. 
mengangkat kamu menjadi umat-Ku dan Aku akan menjadi Allahmu..." Episode ini mirip dengan kemunculan dan identifikasi

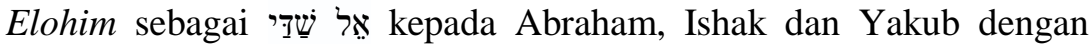
implikasi para pendengar cerita telah lupa konteks masa lalu, sekaligus menjadi semacam konfirmasi bahwa tanah yang telah dijanjikan kepada para Patriak akan menjadi milik bene yĩs ${ }^{e} \bar{a} \dot{e} l$.

Keluaran pasal 3 juga ditenggari memiliki hubungan dengan Keluaran pasal 6; khususnya mengenai istilah אֶלה yang secara historis mendapat pembenaran dan identifikasi (justified and identifying) dirinya sebagai Allah Israel dengan alasan אֶלדהים telah menjadi Allah Abraham, Ishak dan Yakub sejak dahulu kala. Dalam teori Thompson di atas, istilah אֶלה belum tentu memiliki kaitan

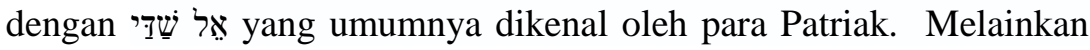
אֶלה yang dimaksud di sini adalah 'élōhê Abraham, 'ēlōhê Ishak dan 'ēlōhê Yakub. Berdasarkan pemikiran ini, penulis pada dasarnya melihat istilah אלדה yang berbeda dengan Allah para Patriak mungkin dimunculkan pertama kali oleh Musa dalam kedua Pasal Keluaran ini berdasarkan pada narasi ketika Musa tertarik untuk melihat semak yang sedang terbakar (namun tidak terbakar), disinilah אֶלדים memperlihatkan sekaligus memperkenalkan dirinya sebagai אֶלה yang disembah oleh ayah mertua Musa (asumsi ini agak prematur,

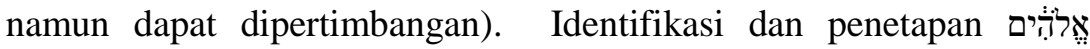
sebagai Allah keluarga ini kemudian membuka pintu bagi alur cerita dari narasi itu sendiri - narasi yang dimulai dari Keluaran 3:11 dengan pertanyaan Musa ""Siapakah aku ini, maka aku yang akan menghadap Firaun dan membawa orang Israel keluar dari Mesir?" Pertanyaan Musa ini menjadi motif utama Musa untuk pergi ke Mesir menghadap Firaun. Metafora di atas pada akhirnya memberikan semacam legitimasi dan identifikasi dari manifestasi ilah itu sendiri; sekaligus merupakan identifikasi bahwa אֶלה adalah Allah mereka - dalam tradisi yang telah dilupakan - Yahweh yang bertemu Musa adalah אָלהּים itu sendiri untuk memberikan penguatan kepada Israel seklaigus 
konfirmasi Allah Israel kepada Firaun. Namun identifikasi Yahweh dan El di sini hanya bermain sebatas pada tataran psikologi semata dan bukan historikal, sebab kedua teks ini tetap berada pada lapisan tradisinya masing-masing; termasuk Allah yang menyatakan dirinya sebagai Allah Patria dan Musa.

Ketika kita melihat argumen Musa saat menerima instruksi dari אֶֶל dalam Keluaran 3:15 "Selanjutnya berfirmanlah Allah kepada Musa: "Beginilah kaukatakan kepada orang Israel:

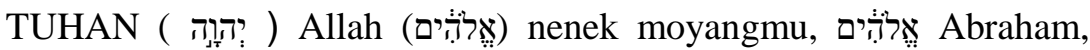

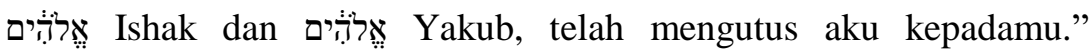
Kalimat ini jika dihubungkan dengan motif yang terdapat pada ayat 16; sekaligus dihubungkan dengan Keluaran pasal 2 dan 23, kita seperti menemukan bahwa saat itu ידונה - lah yang menjadi Allah Israel, apalagi jika memperhatikan Keluaran 3:18, maka terlihat kompleksitas dari identifikasi diri dan hubungan antara keduanya terus terbangun yang kemudian bermuara pada satu ilah saja. Namun demikian, jika memperhatikan dengan seksama teks di atas, kita menemukan dalam ekspansi dari motif di atas; ternyata yֶang yang


orang Ibrani (Tuhan, Allah orang Ibrani - LAI), yang kemudian

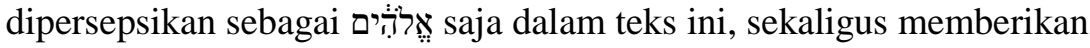
tanda seolah-olah Mesir telah mengenal Allah ini. Kemungkinan besar identifikasi ini dilakukan untuk menggali ingatan lama Israel dan Mesir yang pernah mengenal El saat Yusuf dan Yakub berada dan berdiam di Mesir pada beberapa ratus tahun sebelumnya. Identifikasi ini pada akhirnya menjadi sangat penting untuk dimunculkan apabila hendak menghubungkan adanya ikatan perjanjian Yahweh dengan Allah para Patriak - walau sebatas hubungan psikologis pada akhirnya.

Para penulis kitab Kejadian dan Keluaran pada akhirnya terlihat tidak pernah menolak Politeisme dan Henoteisme kuno Kanaan dan Palestina yang dipercaya memberikan pengaruh terhadap 
sistem agama Israel. Mereka - para penulis sebatas melakukan transformasi dan reinterpretasi atas teks yang sedang disusun. Reinterpretasi ini sangat terlihat dalam teofani yang tercatat dalam Keluaran pasal 3 dan 6, di mana Yahweh sebagai Allah yang berasal dari selatan Palestina mengalami identifikasi dengan istilah אֶלדים yang artinya ilah surgawi hadir kepada mereka yang mengidentifikasikan dirinya sebagai orang "Israel".

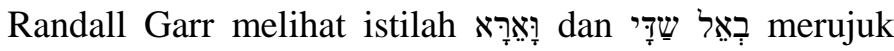
pada subjek yang sama, walaupun frasa kedua memiliki preposisi جִ yang jarang muncul tetapi dalam kasus ini memainkan peran sangat penting; atau yang menandai kapasitas tindakan dari aktor yang

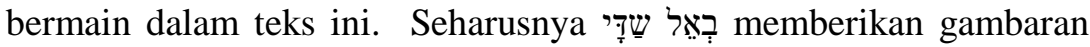
parsial dari subjek preposisi ini membatasi subjek (Allah Musa) dengan peran yang ia


melainkan sebagian saja yang direpresentasikan dengan penanda שֵׁ. Pendekatan Garr ini mirip dengan yang dilakukan Motyer - yang mengikuti formulasi yang dibangun F.M. Cross yang mengklaim terjadi tumpang tindih atribut, julukan dan Nama Diri dari Yahweh dengan El yang mengindikasikan Yahweh pada mulanya merupakan gambaran identik Figur El; dengan kata lain El dan Yahweh pada mulanya identik.

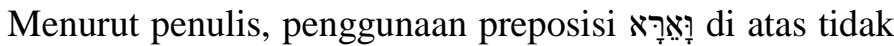

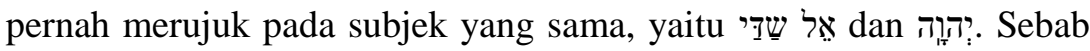

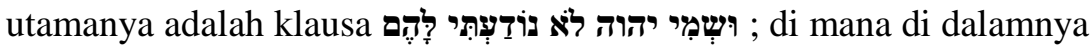

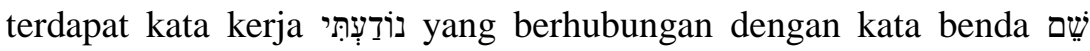
dengan bentuk pertama pronominal suffix וּשְׁמִ Subjek ganda ini pada akhirnya menempatkan kata benda שֵָׁ sebagai latar depan sekaligus

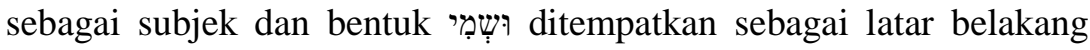
yang bertindak sebagai kendaraan yang terlibat penuh dalam situasi.

${ }^{59} \mathrm{~W}$. Randall Garr, The Grammar and Interpretation of Exodus 6:3, JBL 111 (1992), 388 
Klasifikasi ini menempatkan kata benda sebagai agen dari kata kerja sedangkan pronominal suffix dari kata benda itu memberikan indikasi arti di mana tindakan dilakukan. Dengan ini nama יהוזוה : tidak menjadi pernyataan lengkap bagi dirinya sendiri; selain sebatas ide dari




yang berasal dari Amori merupakan kaum penyembah אָל שֵּר. Para Patriak bahkan melakukan identifikasi ilah ini dengan 'Ēl Kanaan dan seiring berjalannya waktu, epitet ini kemudian ditransfer kepada Yahweh. Konsekuensinya, kita kemudian melihat hadirnya pemikiran אֵל שִָּِ sebagai dewa pegunungan yang menjadi sejalan dengan status 'El dan Yahweh yang sering digambarkan sebagai Allah yang bertahta di atas gunung suci dalam tradisi Ugarit dan Israel dikemudian hari.

Namun demikian, para sarjana lain seperti Biale dan Canney seperti sudah dijelaskan sebelumnya, melihat Istilah seharusnya dipahami tidak sebatas gunung belaka; melainkan buah dada. Pengertian ini telah membawa perubahan siknifikan dalam upaya memahami istilah אֵל שַׁ. Pendorong utama dari perubahan pengertian dan pemberian arti buah dada ini adalah: sang ilah dimengerti sebagai bergender feminin. Aspek feminin yang menempel pada nama shadday inilah yang kemudian membuka ruang hipotesa bahwa ilah shadday adalah ilah perempuan (mother goddesses) yang mungkin identik dengan dewi Athena yang memiliki banyak payudara."60 Biale melihat Shadday sebagai dewi kesuburan yang bekerja mirip dengan Asherah. Karakteristik sebaliknya yang dimiliki el shadday bagi Biale murni hasil bentukan teologi Priest yang menempatkan ilah ini sebagai Allah universal. ${ }^{61}$ Shadday dianggap sebagai ilah yang membawa nama kuno dalam literatur Israel dibuktikan namanya yang hanya muncul dalam puisi-puisi awal

60 David Biale, The God With Breasts: El Shadday in the Bible. HR 20. Number 3 (1982), 249-250

${ }^{61}$ Ibid., 243 
seperti dalam teks ikatan perjanjian Yakub (Kej. 49:25), dalam narasi Billeam serta hadir dalam teks Mazmur 68. Narasi-narasi tersebut dipercaya muncul paling lambat sekitar abad ke 10 SM. Menurut Biale, problematik nama wַ juga muncul dalam bentuk gabungan nama yang dikenal dengan el shadday yang dapat berarti "the god of shadday atau god shadday atau 'ēl yang juga dikenal sebagai shadday. Kitab Kejadian dan kitab Keluaran serta Yehezkiel, terlihat selalu

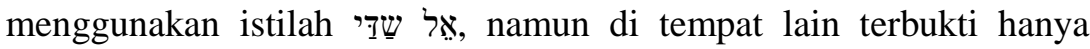
muncul dengan istilah שִ saja. ${ }^{62}$

Akan tetapi ketika memperhatikan kemunculan nama shadday dalam teks-teks Kejadian dan Keluaran yang menghubungkan ilah ini dengan kalimat "bertambah banyak, berbuah, memberikan kesuburan dan memberkati," maka shadday dapat dikategorikan sebagai ilah kesuburan - yang memberkati hasil pertanian dan menambah jumlah anggota keluargamu ketika ia memberkati Rahim para wanita. ${ }^{63}$ Pilihan melakukan proteksi, memberkati, memberikan kesuburan dan menumbuhkan hasil bumi yang dilakukan Shadday, menempatkan Allah ini sebagai Allah kesuburan yang memiliki buah dada atau buah dada 'ēl. Lebih jauh kita melihat bahwa Allah dengan buah dada ternyata merupakan interpretasi alami dari Allah kesuburan dalam kitab Kejadian.

\subsection{Survey Ulangan 32:8-9 Dan Mazmur 82:1}

Smith berpendapat Ulangan 32:8-9 merupakan gambaran nyata Yahweh sebagai anak El yang menunjuk pada terma elyon dalam pasal ini yang merupakan bukti orang Israel saat itu melakukan pembedaan jelas antara Yahweh dengan El di Israel. Yahweh dipahami Israel sebagai ilah yang berasal dari Kanaan. Lebih jauh Smith berargumen:

${ }^{62}$ Ibid., Biale, The God With Breasts , 244

${ }^{63}$ Ibid. 
[This] divine arrangement of the world appears also in versions of Deuteronomi 32:8-9 preserved in Greek (LXX) and the Dead Sea Scrolls... The texts of the LXX and the Dead Sea Scrolls show Israelite polytheism which focuses on the central importance of Yahweh for Israel within the larger scheme of the world; yet this larger scheme provides a place for the other gods of the other nations in the world. Moreover, even if this text is mute about the god who presides over the divine assembly, it does maintain a place for such a god who is not Yahweh. Of course, later tradition would identify the figure of Elyon with Yahweh, just as many scholars have done. However, the title of Elyon ("Most High") seems to denote the figure of El, presider par excellence not only at Ugarit but also in Psalm 82. (Pengaturan ilahi atas dunia muncul dalam versi Ulangan 32:8-9 yang tersimpan dalam LXX dan Naskah Laut Mat...kedua teks tersebut memperlihatkan Politeisme orang Israel yang berfokus pada Yahweh sebagai titik pusat Israel dalam skema lebih besar dunia; namun skema yang lebih besar ini tetap memberikan tempat pada ilah lain dari bangsa lain dalam dunia ini. Namun demikian, walaupun teks ini senyap mengenai siapakah yang menjadi ilah utama dalam sidang ilahi, tetap saja tempat itu diberikan pada Allah yang pastinya bukan Yahweh. Tentu saja tradisi terkemudian akan melakukan identifikasi figur Elyon dengan Yahweh, seperti yang dilakukan banyak sarjana. Akan tetapi, tetap saja titel Elyon (Maha Tinggi) terlihat merujuk pada EL, pemimpin tak tergoyahkan tidak saja di Ugarit, namun dalam catatan Mazmur 82). ${ }^{64}$

Pemisahan nyata antara El dengan Yahweh terlihat ketika Smith menyusun sistem Panteon Ugarit dalam hubungannya dengan panteon Israel. Seperti sudah diterangkan sebelumnya Smith membagi Level

${ }^{64}$ Ibid., Smith, Origin of Biblical Yahwisme, 48-49 
pertama sistem Panteon dihuni oleh El dan pasangannnya Atirat/ Asherah, yang mana Yahweh dan Asherah digambarkan sebagai pasangan Allah di Israel dalam inskripsi Kuntillet Ajrud di kemudian hari. Level kedua dihuni anak-anak El, ke tujuh puluh anak Atirat dan anggota sidang ilahi lainnya. Level ketiga dihuni para dewa yang ahli di bidang tertentu; seperti Kothar wa-Hazis. Pada level ke empat atau terakhir Panteon ini dihuni oleh para dewa yang bertugas sebagai pengantar atau pembawa pesan. Teks Perjanjian Lama seperti 1 RajaRaja 22.19-23; Yesaya 6 dan Daniel 7, menggambarkan hirarki Ugarit ini. El pada akhirnya dinyatakan sebagai dewa Utama dan bukan Yahweh - Yahweh tidak identik dengan El dalam hal ini. Namun kedua level tersebut berperan sebagai Allah yang melakukan tugas pemeliharaan kepada manusia; di dalam konsep "parental gods" Allah yang mengasuh. Ulangan 32:8-9 merupakan teks yang menggambarkan Yahweh sebagai Allah Israel, namun tidak sebagai Yahweh yang "Maha Kuasa" seperti gambaran dalam Perjanjian Lama. Kelihatannya penulis Deuteronomis dalam teks ini lebih menggambarkan atau menempatkan Yahweh sebagai ilah lapis kedua yang berada di bawah kekuasaan El sang kepala Panteon.

Lowel K. Handy yang menyusun argumentasi serupa dengan Smith menetapkan panteon Ugarit sedikitnya memiliki empat hirarki; yang juga dimiliki oleh struktur Pantheon Kanaan, di mana setiap organ dalam struktur panteon ini merupakan dewa-dewi "aktif" yang terus menerus bekerja sesuai takaran tugasnya. Struktur panteon ini dimulai dengan El sebagai Allah Level pertama yang memegang wewenang tertinggi dan berotoritas penuh karena berposisi sebagai pencipta alam semesta yang kuasanya melebihi semua Allah yang ada. ${ }^{65}$ Dalam menjalankan fungsinya sebagai Allah utama, El tidak sendirian. Di sampingnya berdiri satu figur terkenal yaitu Asherah. Di Ugarit, El dan Asherah merupakan pasangan ideal pencipta dan

${ }^{65}$ Stanley A. Cook, The Religion of Ancient Palestine in The Light Of Archaelogy, (London: Oxford University Press, 1930), 26-27 
pemilik surga-bumi beserta segala isinya, serta dipercaya sebagai yang menetapkan penguasa-penguasa di Bumi. El dan Asherah digambarkan sebagai penguasa bijak dan agung (mulia), yang mengetahui bagaimana harus mengatur alam semesta ini dan mampu menetapkan dengan tepat tugas-tugas tertentu kepada dewa atau dewi yang berada di bawah mereka dalam cerita mitologi Kanaan. Namun demikian, keduanya tetap dapat melakukan kegiatan (keputusan) secara sendiri-sendiri atau mungkin berkonflik satu dengan lainnya dengan tidak menghilangkan status mereka sebagai pemimpin tunggal yang hadir bersama-sama dalam narasi mitologi Kanaan.

Pada level kedua muncul figur Ba'al, Anat, Shapsu, Mot dan Yam yang merupakan dewa-dewa aktif yang bertugas mengurus kosmos yang ditemani oleh dewa Matahari, dewi Bulan dan dewadewi Bintang. Para dewa level ini digambarkan memiliki kekuasaan/ kekuatan tidak terbatas atas manusia. Posisi ketiga ditempati oleh dewa-dewi yang ahli dalam bidang tertentu seperti Kothar wa-Haziz yang dalam teks Ugarit dikatakan membuat istana dan senjata untuk Ba'al serta tenda untuk Yam. Pendek kata, golongan ketiga dihuni para dewa dengan keahlian khusus. Dan posisi terakhir dari sistem panteon ini ditempati oleh para dewa pembawa pesan yang disebut Ilm. Mereka dapat juga disebut sebagai "budak" kerajaan Allah. Golongan terakhir ini dikenal dengan istilah $m l$ 'ak, (yang khusus melayani dewa-dewi lainnya) yang umumnya dikenal sebagai "firman hidup" dalam naskah Ugarit. Kelompok terakhir ini adalah juru bicara dewa pengutusnya. Mereka hanya menerima pesan, membawa pesan serta wajib berkelakuan baik. Mereka berada dalam lingkup kerajaan, namun tidak memiliki dominasi apapun - walau tetap dalam status sebagai dewa - mereka adalah golongan dewa, namun bukan dewa yang mengeluarkan perintah/ instruksi atau keputusan eksekutif.

Perjanjian Lama memiliki echo gambaran Kanaan tentang model tingkat empat sistem Panteon di atas; bahkan memiliki contoh dari hirarki keilahian itu sendiri, namun tidak seperti El yang 
menjadi penguasa Panteon, di Israel, level pertama Panteon dikuasai oleh Yahweh. Penulis Raja-Raja menggambarkan Ia memerintah bersama Asherah yang dikenal dengan Queen Mother 'ratu surgawi' dan menjadi sesembahan utama Yehuda pada pertengahan Milenium pertama. Hirarki level kedua ditempati Ba'al, Mot, Yareah dan Astarte. Contoh mitologi ini dapat terlihat dalam Yosua 10:12, di mana ada kultus Dewa Matahari yang ditemukan dalam bait Allah Yerusalem (bd. Yeh.8), serta dewa Mot yang muncul dalam beberapa narasi profetik di Hosea dan Yeremia; yaitu Yahweh yang digambarkan akan menghukum Israel dan Yehuda karena menyembah mereka. Level ketiga nampaknya dihuni oleh Ba'al Zebub yang walaupun bukan Allah Israel dan Yehuda, namun disembah oleh raja Ahaz. Sedangkan level ke tiga dari susunan Panteon Israel ini dikuasai oleh para ilah pembawa pesan; dalam hal ini disebut Nehustan.

Karel Van Der Toorn mendukung argumentasi El dan Yahweh dua ilah berbeda. Menurut Van der Toorn, ${ }^{66}$ kultus Yahweh tidak berasal dari Palestina. Dia tidak disembah oleh orang di dunia Semit Barat, argumen ini dibuktikan dengan tidak hadirnya kultus Yahweh di Siria maupun di Palestina. Toorn berpendapat jika istilah Yahweh memiliki arti "he blows" yang dalam bahasa Syriak berarti hawwe, "angin", maka Yahweh aslinya adalah Allah badai (sejajar dengan Ba'al) yang berasal dari Edom atau Midian. ${ }^{67}$ Kompetesi antara Yahweh dengan Ba'al pada era monarki lebih dikarenakan

${ }^{66}$ Karel Van der Toorn. (editor), Dictionary of Deities and Demons in the Bible, (Brill, Leiden Boston: William B. Eerdsmann, 1999), 893-915

${ }^{67}$ Ulangan 33:2-3 secara ekplisit memberitakan YHWH datang dari Sinai dan dari Seir (Edom) bersama-sama dengan qudsu (Asherah). Teks yang sama muncul juga dalam nyanyian Deborah dalam Hakim-Hakim 5: 4, "Tuhan, ketika engkau bergerak dari Seir, ketika engkau melangkah maju dari Edom..." Kedua teks ini (teks Ulangan memberikan ide YHWH datang dengan pasangannya Asherah), menggambarkan pengertian penulis Deuteronomi bahwa YHWH bukan Allah asli Israel, melainkan kepunyaan orang Edom. 
promosi kultus $\mathrm{Ba}$ 'al oleh raja Omri di Israel. Namun demikian, Yahweh terbukti banyak mengusung julukan yang biasa diberikan kepada Ba'al. Contoh; gunung Zion yang terdapat dalam Mazmur 48:3 merupakan echo dari gunung Zapon yang biasa dihubungkan dengan Ba'al. Demikian juga epitet Yahweh yang digambarkan sebagai "Yahweh pahlawan perang yang melintasi langit," dipercaya sebagai julukan yang biasa diberikan kepada Ba'al yang adalah dewa perang.

Walaupun demikian, Van der Toorn melihat figur El lebih sering dihubungkan dengan sosok Yahweh daripada kepada Ba'al. Dalam narasi Patriakal kitab Kejadian, istilah seperti El-Olam atau El-Elyon lebih sering dipakai untuk menunjuk kepada epitet Yahweh. Dengan memperhatikan hal tersebut, maka, Van der Toorn menyimpulkan EL dan Yahweh merupakan ilah tidak identik pada mulanya dan kemudian berfusi sebagai hasil teologisasi para editor teks Perjanjian Lama. Hasil penggabungan kedua ilah tersebut berujung pada Yahweh yang digambarkan mewarisi beberapa julukan El, seperti: "bapa dari segalanya," "pahlawan balatentara Tuhan," "pahlawan gagah perkasa," dan lain sebagainya pada era terkemudian. Selain itu, karena Yahweh sering dihubungkan dengan El, maka pasangan El, Atirat (Asherah) pada akhirnya dihubungkan juga dengan Yahweh. Dengan ini kita melihat Israel sangat berwarna Monolatri daripada Monoteis. Bagi Van Der Toorn praktek Monolatri yang dilakukan Israel tidak boleh dilihat sebagai praktek Monoteisme. Karena bukan saja Israel tetap mengakui keberadaan ilah lain selain Yahweh, namun, mereka juga mengenal lebih dari satu Yahweh. ${ }^{68}$ Argumen ini kelihatannya dibangun Toorn berdasarkan munculnya dua nama Yahweh (Yahweh Teman dan Yahweh Shomron dalam inskripsi Kuntillet Ajrud). Untuk itu Toorn menyimpulkan situasi

${ }^{68}$ Dalam penemuan naskah di Kuntilet Ajrud dan Kirbet-el-Khom, Yahweh disebut sebagai Yhwh Samaria (kemungkinan sesembahan Israel), dan Yhwh Teman (kemungkinan sesembahan orang Yehuda di selatan). 
religius Israel mula-mula bukan saja Politeisme semata, melainkan "poly-Yahwisme".

Lebih jauh Van der Toorn menilai setiap opini dan spekulasi yang berhubungan dengan identifikasi El dan Yahweh harus dilakukan dengan sangat kritis. Selain itu, penafsir harus ingat bahwa peran El sebagai ilah tertinggi dalam sistem agama Kanaan (juga Israel) telah menjadi tidak begitu penting atau mulai turun pada era jaman Besi dan digantikan ole Yahweh; hal ini menjelaskan mengapa tidak ada jejak polemik dalam teks Ibrani melawan figur El oleh para nabi Yehuda dan Israel. Menghilangnya peranan El seperti yang disebut di atas pada akhirnya dapat dianggap sebagai titik utama identifikasi figur El oleh Yahweh di kemudian hari. Yahweh digambarkan mulai menggunakan beberapa atribut yang selama ini dilekatkan kepada El sampai akhirnya hanya Yahweh semata yang muncul dan mendominasi sistem agama Israel. ${ }^{69}$

Georg Fohrer yang mengikuti model evolusi Albrecht Alt, melihat Perjanjian Lama memuat beberapa informasi berbeda mengenai asal muasal Yahwisme, namun dari beragamnya informasi yang ada, Fohrer secara implisit menyimpulkan bahwa agama Yahweh dibawa oleh Musa dari orang Midian saat ia berada di wilayah Sinai. Yahweh yang disembah oleh suku-suku Midian di padang gurun Aqabah, diperkenalkan Musa kepada Israel sebagai Allah yang akan membawa mereka menuju Tanah Perjanjian yang penuh susu dan madu. Berdasarkan narasi di atas, Yahweh kemudian membuat ikatan Perjanjian dengan Israel, di mana ia menjadi Allah mereka dan Israel menjadi umatNya.

Ketika Musa dengan Allah Yahwehnya masuk Palestina; sistem Yahwisme ini serta merta meresap ke dalam klan Yusuf yang sudah ada terlebih dahulu; klan yang telah memiliki El sebagai Allah sesembahan mereka. Hasilnya; Yahwisme dengan cepat dikenal oleh suku-suku tersebut yang berjalan beriringan dengan penyembahan

${ }^{69}$ Ibid., Van der Toorn, Dictionary of Deities, 916-917. 
terhadap El yang sudah hadir sebelumnya. Pertanyaan "apakah sukusuku Yusuf ini menerima atau tidak Yahwisme yang dibawa Musa? Atau apakah agama Yahwisme dipraktekkan umum di seluruh sukusuku yang akhirnya disebut Israel sebagai keturunan Yakub? Bagi Fohrer, praktek ini membuat masing-masing suku-suku tersebut; suku Israel Keluaran Mesir dan suku Yusuf yang telah berada di Kanaan lebih dahulu, tetap ingat terhadap El dan Yahweh mereka masingmasing - sekaligus terus mempertahankan ikatan suku mereka sebagai bagian anak-anak Yakub. Suku-suku Yusuf menerima suku-suku keluaran Mesir yang dipimpin Musa ini sebagai kelompok penganut Yahweh yang selanjutnya bermuara pada operasional praktek El dan Yahwisme bersama-sama. Jadi, penyatuan suku-suku tersebut pada akhirnya terlihat lebih bersifat sosial daripada religius. Mereka mengaku sebagai am Yahweh, oleh karena itu dimasukkan dalam komunitas Yahweh. Dengan ini kita mengerti mengapa Israel tetap mempertahankan tradisi para Patriakh; bahkan setelah pengadopsian agama Yahweh ini sekaligus secara teologis dikoneksikan dengan umat Yahweh keluaran Mesir pada saat bersamaan. Dengan formula ini, sangat dimungkinkan untuk terus menghubungkan Israel dengan Yahweh sekaligus tidak meninggalkan penyembahan terhadap Allah para Patriak.

Perkembangan di atas hanya terjadi karena berbaurnya orang Israel dengan penduduk Kanaan yang konsekuensinya mereka mengadopsi cara hidup penduduk Kanaan. Ismar J. Peritz menggambarkan sebagai "Kehidupan nomadis yang mulai ditinggalkan." Israel yang mulai hidup menetap dengan membangun kota; membuat rumah permanen, membuka ladang pertanian, menanam anggur, mereka juga belajar dari orang Kanaan bagaimana cara menanam pohon ara dan pohon kurma, cara memeras anggur, cara memproduksi minyak zaitun dan membuat tembikar. Demikian pula mereka belajar bagaimana cara berternak yang baik, mengambil 
hasil dari ternak berupa daging, wool dan susu telah dipelajari orang Israel dari orang Kanaan." 70

Proses asimilasi yang terjadi berujung pada agama Yahweh yang terus menerus mengadopsi model agama El; lengkap dengan berbagai ritual dan Kalender perayaannya (mis: perayaan Roti Tak Beragi, perayaan Tujuh Minggu, dan perayaan Tabernakel). Nama Yahweh ditenggarai mulai surut, sebaliknya nama El yang kemudian mendominasi. Bahkan pada masa tertentu, Ba'al menjadi Allah sesembahan orang Israel - sederajat dengan penyembahan Yahweh - yang dibuktikan dengan hadirnya istilah Ba'al Perazim yang dikumandangkan Daud ketika 'Allah memberikan terobosan' kepadanya dalam konflik dengan orang Filistin (2 Sam. 5:20; 1 Taw. 14:11). Walaupun demikian, penyembahan terhadap Yahweh terlihat masih bertahan. Yahweh terlihat tetap disembah dalam ritual-ritual di tempat-tempat seperti Beer-sheba, Hebron, Mamre, Bamoth di Gibeon, Bethel, Shiloh, Gunung Tabor, dan beberapa tempat lainnya; ia disembah bersama-sama dengan figur El.

Berasimilasinya Yahweh dengan Panteon Kanaan memiliki konsekuensi Israel pada akhirnya mengambil beberapa model perayaan Kanaan seperti; perayaan Roti tak Beragi, Perayaan Tujuh Minggu, dan perayaan Tabernakel yang khas Kanaan karena warnanya yang agrikultur. Perayaan-perayaan ini diberi nuansa Yahweh di Israel dan dihubungkan dengan sejarah keselamatan. Tidak sampai di situ saja, mulai terjadi pengadopsian beberapa hukum Kanaan karena umat Israel harus beradaptasi dengan situasi barunya saat hidup menetap. Pada titik inilah hukum Kasuistik Kanaan (conduct law) yang khusus mengatur masyarakat yang sudah menetap diadopsi Israel.

Periode Monarki adalah periode di mana Yahwisme menjadi agama resmi kerajaan; terutama di Bait Allah kerajaan

${ }^{70}$ Ismar J. Peritz, Old Testament History, (New York: The Abingdon Press, 1923), 114 
disamping agama Kanaan yang dipraktekkan di seluruh Israel. Sementara itu, berkembang juga di Israel pergerakan-pergerakan keagamaan yang berseberangan dengan posisi di atas; penyembahan terhadap Yahweh tetap berjalan di Kanaan. Nyanyian Deborah yang mengagungkan Yahweh, konsep Nazar (Samson) dan eksistensi kaum Rekhab yang kesemuanya nomadis, mengindikasikan adanya penolakan budaya agrikultur Kanaan, serta menolak sinkretisme Yahweh-Kanaan yang sudah tertanam di Israel saat itu. Kelompokkelompok ini mencoba mempertahankan Yahwisme Sinai tetap murni.

Pada akhirnya Fohrer menyimpulkan Israel periode monarki merupakan kelompok masyarakat yang mencoba mengadopsi ide Yahwisme dan Kanaan sekaligus. Kelompok ini berusaha mempertahankan Yahwisme dalam keseharian mereka sekaligus mengadopsi budaya agrikultur Kanaan untuk dapat bertahan di daerah yang baru mereka miliki. Dalam pemahaman kelompok ini, Yahweh bukan lagi sekedar Allah yang memberikan kemenangan dalam peperangan (seperti saat di padang gurun dan masuk Kanaan), melainkan sosok Allah ini dapat juga sebagai Allah yang melindungi umatnya beserta dengan segala ternak peliharaan dan hasil pertanian/ perkebunan mereka. Dengan ini Yahweh diasosiasikan dan mendapat gelar baru sebagai Allah agrikultur; gelar yang identik dengan epitet Ba'al. $^{71}$ Fohrer kelihatannya memisahkan El sesembahan Patriak dengan El sesembahan orang Kanaan. Bagi Fohrer, El yang disembah suku Yusuf merupakan El yang disembah leluhur mereka tanpa mengalami distorsi sampai saat itu.

Berbeda dengan Smith, Handy, Toorn atau Fohrer yang meyakini El dan Yahweh merupakan dua ilah berbeda, Frank Moor Cross percaya El dan Yahweh pada mulanya adalah ilah identik yang pada waktu tertentu dalam sejarah Israel berfusi - kemudian berpisah

${ }^{71}$ Georg Fohrer, History of Israelite Religion, (Nashville: Abingdon Press, 1972), 53-202 
kembali dalam penulisan pasca Pembuangan. Menurut Cross ${ }^{72}$ istilah 'il selalu muncul dengan bentukan apelatif umum yang berarti 'tuhan', 'ilah,' dalam bentuk awal di manapun bahasa Semit dipergunakan. Teks Ugarit tanpa ragu mengindikasikan ilu', atau el, sebagai Nama Diri (proper name) dari kepala panteon Kanaan itu sendiri. ${ }^{73}$ 'Il sebagai Nama Diri, umumnya muncul dalam teks-teks puisi, mitis dan epik, yang merupakan teks-teks panteon dan bait suci setempat. Cross juga melihat istilah 'il sering muncul dalam catatan kuno Akkadia dan dalam suku Semit Arab yang dipergunakan sebagai Nama Diri. Penggunaan umum Nama Diri 'il - yang kemudian diidentifikasi sebagai $E l$ - yang adalah ilah utama dari bangsa Semit Mesopotamia - mendapat dukungan dari inskripsi-inskripsi yang ditemukan di Ugarit; yang bahkan diinformasikan nama ini terindikasi dimiliki orang-orang sejak era Proto-Semit.

Nama Diri ataupun apelatif dari elemen el - yang dikombinasikan dengan bentukan substantif atau ajektif - ditenggari muncul juga dalam narasi Patriak di kitab Kejadian. Epitet ini tersimpan dalam tradisi Israel sebagai nama ilah yang selanjutnya dipanggil atau disebut Yahweh. Formula ini pada akhirnya menyimpan dua tradisi bersamaan dalam cerita kitab Keluaran (pasal 3 dan 6), disebutkan nama Yahweh tidak pernah disebutkan sampai pada era Musa. Menurut teks ini, terjadi semacam keberlanjutan antara tradisi keagamaan para Patriak dengan El sebagai Allah sesembahan mereka dengan tradisi keagamaan Yahwistik Israel di bawah kepemimpinan Musa. Menurut Cross, teks-teks Keluaran di atas mengindikasikan bahwa ada dua tataran agama yang beroperasi dengan dua tingkat berbeda - yang tercatat dalam sejarah perkembangan agama Israel, yang di kemudian hari El akhirnya terindikasi dalam tradisi biblikal sebab seringkali digunakan sebagai

${ }^{72}$ Frank Moor Cross, la 'él, in Botterweck et al (eds) vol 1 (19742001), 242-261.

${ }^{73}$ Model ini dapat juga berbentuk apelatif 
nama alternatif dari Yahweh. Tumpang tindih atribut, julukan dan Nama Diri dari Yahweh dengan El mengindikasikan bahwa Yahweh pada mulanya merupakan gambaran identik Figur El; dengan kata lain El dan Yahweh pada mulanya identik. Namun El dan Yahweh Pada waktu kemudian berpisah - proses serupa terjadi dengan kultus Israel yang berpisah dan kemudian melakukan pembedaan dirinya dengan konteks politeistik yang ada saat itu. ${ }^{74}$ Akan tetapi pemisahan El dan Yahweh ini tidak bertahan lama, pada era pembuangan, kembali El dan Yahweh melakukan reuni yang pada akhirnya muncul hanya satu sebutan saja bagi Allah Israel, yaitu Yahweh.

Selain itu, Cross melihat Allah tanpa nama yang disembah oleh para Patriak dalam terma 'Allah bapaku', merupakan ilah-ilah berbeda pada mulanya - kemudian berkembang dalam tradisi Israel - bergabung atau bersatu dalam bentuk Allah tunggal yang secara artifisial terikat pada geneologi para Patriak yang kemudian terasimilasi pada Yahweh. Allah-Allah ini kemudian dikenal dengan el elohe Abraham, el elohe Laban, Pahad Ishak dan abir Yakub yang dikenal sebagai Allah maha kuasa El Shadday, sekaligus terindikasi sebagai kelanjutan hubungan antara agama pra-Yahwisme dengan agama suku para leluhur yang terekam dalam teks Keluaran 3.13-15. Model agama para Patriak di atas kelihatannya berbeda dengan bentuk agama Kanaan, di mana indikasinya terlihat pada penyebutan nama 'Allah para leluhur' yang merupakan patron dari setiap suku yang jelas berbeda dengan sebutan ilah-ilah Kanaan.

Pendekatan yang dilakukan Cross ini dapat dipergunakan untuk memberikan iluminasi dan klarifikasi atas hadir serta keberlanjutan Allah para Patriak dan Kanaan; yaitu El dan Yahweh, sebagai Allah Israel. Cross membuat kesimpulan bahwa Yahweh merupakan nama kultus dari El itu sendiri. Selain itu, Yahweh dapat juga merupakan epitet dari El sebagai ilah utama orang Midian atau Keni yang bertemu Musa di padang gurun. Nama ilahi El dalam kitab

${ }^{74}$ Ibid., Cross, la 'èl, in Botterweck et al, 260 
Kejadian sepertinya merujuk pada El Allah Kanaan dalam tradisi Patriak. Dalam perkembangan selanjutnya El dinyatakan mulai menurun peran dan fungsinya di Kanaan dan Israel (seperti argumentasi Toorn), oleh karena itu Yahweh kemudian melakukan reorganisasi dirinya untuk dan atau berpisah dari El. Akan tetapi segala atribut, epitet dan apelasi yang biasa dikenakan El kemudian dipergunakan Yahweh selama proses persekutuan, terus bertahan dan dipergunakan. Namun demikian, tetap tidak dapat dipungkiri bahwa semua figur Yahweh pada awalnya dinyatakan berasal dari figur El. ${ }^{75}$ Alasannya adalah: sepanjang sejarah Israel variasi dari nama El terus menerus diterima dan dipergunakan untuk menyebut titel Yahweh.

Cross pada akhirnya dapat mendemonstrasikan adanya hubungan (sharing) identitas keagamaan antara Israel dan Kanaan yang sebelumnya dianggap beroposisi dalam tesis Alt. El adalah Allah Patriakal dan bukan Allah kerajaan, sekaligus ia melihat hubungan antara El dan Ba'al dalam teks Ugarit sebagai bersekutu dan bukan berkonflik. Bagi Corss, jika El dihubungkan dengan Yahweh, maka dua sosok ini merupakan Allah identik di mana nama Yahweh hanya berfungsi sebagai julukan dari El karena epitet (julukan) tersebut di mengerti sebatas bentuk kausatif, seperti "Dia (El/Yahweh) yang menciptakan bala tentara surgawi," dengan karakter El yang mendapat perhatian utama.

Murid-murid Cross seperti Conrad E.L'Heureux, Richard J. Clifford, dan E. Theodore Mullen, Jr. meneruskan - bahkan mengembangkan ide Cross dengan menempatkan El dan Ba'al tidak dalam konflik serius seperti yang dipahami Kapelrud, Pope dan Oldenburg. Dasar argumentasi mereka adalah: tahta El bersifat kekal, sedangkan tahta $\mathrm{Ba}$ 'al bersifat dinamis yang harus dipertahankan terus-menerus dari dewa-dewa lain seperti Mot. Pada akhirnya dapat disimpulkan bahwa El dan Ba'al adalah raja dengan natur berbeda, di

${ }^{75}$ Proses ini dapat diurutkan: pada mulanya ilah identik, berpisah dan berbeda, kemudian bersatu kembali. 
mana Ba'al, Yam, dan Mot tunduk kepada otoritas El. El tidak pernah ikut campur dalam perseturuan dewa-dewa muda lainnya karena perseteruan mereka lebih didorong kepentingan untuk menguasai alam kosmos dan bukan tahta El.

Hipotesis Cross di atas diperkuat oleh Johannes De Moor. Bagi De Moor, Yahweh - El menjadi semacam pengikat antara sukusuku di Israel. Mereka membagi konten dan tradisi Yahweh - El sebagai Allah identik; sekaligus bersama-sama Israel menerima sosok ilah ini sebagai satu-satunya Allah yang ditinggikan. Sehingga dapat disimpulkan Yahweh dan El merupakan Allah identik yang namanya sering bertukar tempat. Namun demikian, ilah ini sangat berbeda dengan Ilu yang ditemukan dalam teks Ugarit. Ilah ini juga telah mengambil semua atribut Ba'al; bahkan lebih hebat dari Ba'al karena Yahweh mampu mengalahkan maut. Penulis juga melihat De Moor percaya Yahweh yang lahir jauh sebelum era Musa dan datang dari Selatan (Seir, Paran) sama sekali tidak terkait dengan catatan biblikal mengenai Yahweh yang melepaskan Israel dari Mesir.

Di tengah arus Politeistik yang ada saat itu, Yahweh berkembang menjadi Allah yang "pencemburu" - cemburu terhadap ilah lain. Konsep ini nampaknya menciptakan ancaman serius terhadap kelangsungan Politeisme; sebab tidak ada lagi ruang bagi dewa/ilah lain untuk memainkan peran yang berarti. Jika perihal eksklusivisme ini dapat diterima sebagai karakteristik penyembahan Israel; bahkan jauh sebelum Musa - mungkin telah muncul pada era para Patriak, maka kita tidak punya pilihan selain kembali ke era di mana para Patriak hidup dan memainkan perannya yang diperkirakan pada sekitar era Jaman Perunggu Akhir. Pada era ini kita juga mendapat informasi karakteristik agama para Patriak sebagai "hanya menyembah akan satu Allah saja," yang biasanya dipanggil dengan Allah sang bapa, atau Allah para leluhur yang memiliki (menjalin) ikatan personal satu dengan lainnya. Pada akhirnya De Moor menyimpulkan bahwa Allah para Patriak bukan sebatas numen lokal 
atau semacam Allah leluhur abstrak yang juga berada di bawah level El kepala Panteon Kanaan. Melainkan ia dinyatakan sejajar dengan Ilu, Marduk dan Amun-Re. Namun pertanyaan yang muncul bagaiman El berubah menjadi Yahweh di Israel?

Seperti sudah dijelaskan sebelumnya De Moor menolak semua teori keberadaan Yahweh dari sumber Priest; sumber pasca Pembuangan ataupun sumber Elohis dan Yahwistis. Dia juga menolak ide terjadinya asimilasi antara El dengan Yahweh saat Israel mulai masuk dan berdiam di Kanaan. Penolakan serupa juga dilancarkan De Moor terhadap argumen yang menganggap Yahweh sebagai hasil dari suatu proses evolusi dari bentuk awal yang disebut El, ketika Israel bergabung dan sedang bergumul di Kanaan. Bagi De Moor, Yahweh awalnya merupakan satu dari sekian banyak ilah yang disembah oleh suku-suku Israel kuno. Yahweh telah hadir bersama dengan El serta memiliki aspek yang mirip dengan El dalam Panteon Ugarit. Jadi Yahweh bukanlah Allah asing yang kemudian berfusi dengan EL di Kanaan seperti yang selama ini diasumsikan panyak peneliti (Smith, Toorn, Handy), melainkan ia dapat disebut sebagai manifestasi dari El sejak mulanya. ${ }^{76}$

\subsubsection{Analisis Ulangan 32:8-9}

Naiknya Yahweh sebagai ilah tertinggi di Israel tentunya tidak terlepas dari konsep sidang ilahi yang dianut orang Kanaan dan Israel; khususnya yang terdapat dalam teks Ulangan 32 dan Mazmur 82 yang pernah disinggung penulis dalam bab II disertasi ini. Apabila menelisik argumentasi Smith, Handy, Ackerman dan Cross, Yahweh tampaknya berperan sebagai Allah utama sekaligus sebagai Allah level dua di Israel yang mana terlihat dalam teks Ulangan 32:8-9 versi Qumran dan LXX. Sedangkan MT memiliki pembacaan berbeda

${ }^{76}$ Johannes C. De Moor, The Rise Of Yahwism: The Roots of Israelite Monotheism, (Belgium: Leuven University Press, 1990), 223-254 
dengan kedua translasi di atas - sekaligus menimbulkan polemik terjemahan. Teks Masoret membaca Ulangan 32:8-9 sebagai berikut:

8 9

Ulangan 32:8 dalam terjemahan MT dibaca sebagai berikut: "When the Most High gave inheritance to the nations, when he divided the sons of Adam / He set the boundary of the people according to the numbering of the sons of Israel" (LAI: ay.8, Ketika Sang Mahatinggi membagi-bagikan milik pusaka kepada bangsa-bangsa, ketika Ia memisah-misah anak-anak manusia, maka Ia menetapkan wilayah bangsa-bangsa menurut bilangan anak-anak Israel. Ay.9, Tetapi bagian TUHAN ialah umat-Nya, Yakub ialah milik yang ditetapkan bagi-Nya). NASB, LAI dan KJV, mengikuti terjemahan MT; khususnya pada penggunaan frasa "anak-anak Israel." Sedangkan LXX menterjemahkan teks tersebut; khususnya Ulangan 32:8 sebagai:

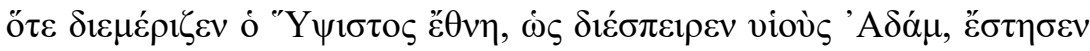

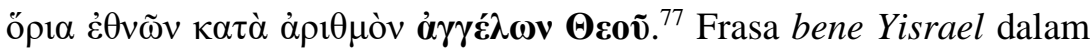


oleh LXX. Perubahan yang dilakukan oleh LXX di atas kelihatannya dilakukan sebagai upaya menutupi ekspresi politeistik yang dimiliki Ulangan 32:8 kepada pembacanya, untuk itu mereka mengganti teks tersebut dengan frasa $\alpha \gamma \gamma \varepsilon \dot{\lambda} \omega v \Theta \varepsilon o \tilde{v}$ - walaupun tetap tidak menutupi warna Politeisme dalam teks itu sendiri. Sedangkan Qumran 4QDeut ${ }^{j}$ yang memiliki terjemahan hampir serupa dengan MT, mempertahankan frasa "bene Elohim" dalam terjemahannya yang kemudian diikuti oleh RSV dan NRSV. Mayoritas sarjana ANET

${ }^{77}$ LXX Charles Thompson memiliki terjemahan "angels of god" pada bagian yang diterjemahkan MT sebagai "bene Yisrael", sedangkan LXX NETS tr. Melvin K. H. Peters menterjemahkan bagian tersebut dengan "divine sons". 
melihat Ulangan 32.8-9; khususnya pasal 8 yang merujuk kepada bene Yisrael dalam MT, merupakan refleksi teologis dari teks asli yang terdapat dalam catatan Qumran 4QDeut ${ }^{\mathrm{j}}$ dan Septuaginta. ${ }^{78}$

\section{Bagi Michael S. Heisser teks LXX dan Qumran} Q4QDeut ${ }^{j}$ berada di atas Teks Masoret - argumen yang mirip dengan mayoritas sarjana ANET. Akan tetapi, Heisser menolak semua pemikiran yang menyatakan titel Elyon dalam Ulangan 32:8-9 merujuk pada $\mathrm{El}$ dan bukan kepada Yahweh. Alasan penolakan Heisser adalah: pertama, bentuk dari Ulangan 32 menggambarkan Yahweh sebagai Elyon (Maha Tinggi) dalam pasal ini. Narasi 'tuntutan pengadilan' yang tergambar dalam pasal ini serupa dengan gambaran yang biasa dimiliki Yahweh sebagai sang penuntut khususnya berhubungan dengan Israel umat pilihannya - umat yang meninggalkan Tuhan sang Batu Karangnya (32:4-5) dan menyembah Allah lain yang berada di bawah kuasa Yahweh. Yahweh sang 'penuntut' kemudian menjatuhkan penghukuman (32:14-17). Poin dari argumentasi ini adalah seperti dalam Mazmur 82, Yahweh yang adalah ilah tertinggi - bahkan lebih tinggi dari segenap anggota sidang dan pengadilan itu sendiri dan karena ia adalah Allah tertinggi, maka hanya Yahweh yang memiliki otoritas menjatuhkan tuntutan dan hukuman. ${ }^{79}$

Kedua, kembali kita melihat Heisser melihat pemisahaan EL dan Yahweh dalam Ulangan 32:8-9 sangat bergantung pada tafsiran yang menempatkan כalam ayat 9 sebagai adversatif/antithesis dan menimbulkan pertentangan dengan Elyon dalam Ulangan 32:8 dan Yahweh dalam Ulangan 32:9 (namun demikian [כ] porsi Yahweh adalah umatnya), atau sebaliknya. Tigay menurut Heisser, menetapkan כי בי 32:9 sebagai bentuk

78 Penulis sepakat dengan pandangan mayoritas di atas mengingat MT telah memasukkan nuansa teologis dalam teks Ulangan 32.8-9 di atas dengan maksud dan tujuan tertentu.

79 Ibid., Heiser, The Divine Council, 83-85 
empatik: "dan lo (כ), porsi Yahweh adalah umatnya." Sanders dapat menerima bentuk adeversatif El dengan Yahweh. ${ }^{81}$ Menurut Heisser, apabila para penafsir tidak memiliki konsensus terhadap arti yang muncul, maka pembacaan awal yang harus dipertahankan; yaitu El dan Yahweh ilah identik.

Ketiga, para sarjana Ugarit telah memperhatikan istilah "Maha Tinggi" (elyon) tidak pernah digunakan dalam hubungannya dengan EL di Ugarit, melainkan Ba'al yang lebih sering menggunakan istilah tersebut dalam frasa b'l 'lyn. Berdasarkan argumentasi ini, maka pemikiran yang menghubungkan El dengan Elyon menjadi mustahil dalam teks Ulangan 32:8-9. Argumentasi Heisser pada bagian ini terlihat lemah. Menurut penulis, 'Ēl 'Ēlyōn dipercaya sebagai kepala dari Panteon yang berlokasi di Kanaan; dalam hal ini di Yerusalem; kota yang didedikasikan kepada Allah Salem. ${ }^{82}$ Pada dasarnya kata 'E$l$ tidak membawa masalah sama sekali mengingat terminologi ini umum dipergunakan untuk menunjuk kepada suatu ilah dalam lingkup Semit (Ugarit, Arab, Aram, Ibrani dan Kanaan). Penggunaan istilah Elyon yang umum tersebut membuka peluang titel ini dapat juga dikenakan kepada Yahweh - seperti terlihat identifikasinya dalam Kejadian 14:22 yang muncul dalam kalimat

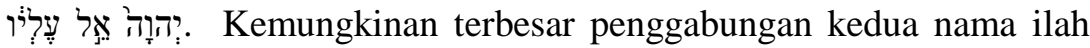
dalam teks di atas karena terjadinya penggabungan kultus di Yerusalem. Apabila Kejadian 14:22 dapat menghubungkan antara Ēlyōn dengan Yahweh, maka munculnya kedua nama tersebut dalam Ulangan 32:8-9 merupakan bentuk keterkaitan yang wajar.

80 Jeffrey H. Tigay, The Jewish Publication Society Torah Commentary: Deuteronomy: The Traditional Hebrew Text with the New JPS Translation, (Philadelphia: Jewish Publication Society, 1996), 303

81 Paul Sanders, The Provenance of Deuteronomy 32. Oudtestamentische Studien 37. Edited byJohannes de Moor. (Leiden: E. J. Brill, 1996), 373

82 Th. Vriesen, The Religion of Ancient Israel. (Philadelphia: The Westminster Press, 1967), 53 
Bukti untuk menguatkan argumentansi di atas kiranya diperoleh dengan melihat munculnya nama 'Ēl dalam inskripsi stela Sfire 1A (750 SM) yang berisi perjanjian antara raja Bargaya dan Attarsamek. Nama Ēlyōn hadir dalam inskripsi ini bersama-sama dengan nama-nama ilah lainnya seperti Marduk dan Shamash, untuk menjadi saksi atas ikatan perjanjian tersebut. ${ }^{83}$ Ēlyōn jika dilihat dari inskripsi Sfire ini, kemungkinan besar merupakan Allah independen semenjak namanya dipasang bersama-sama dengan ilah lainnya. Ia mungkin menjadi penguasa utama di Yerusalem sampai periode monarki. Periode selanjutnya epitet Sang Maha Tinggi ini ditempelkan kepada Yahweh yang mengalami sentralisasi sebagai Allah monarki di Yerusalem.

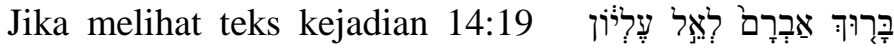

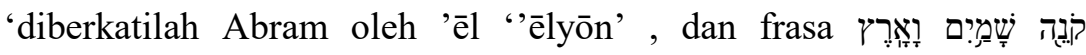
'pencipta langit dan bumi' yang digabung dalam satu kalimat sehingga menjadi “diberkatilah Abram oleh 'êl 'ēlyōn' pencipta langit dan bumi." Dari gabungan kedua kalimat di atas, terlihat figur 'èl 'ēlyōn' bukan saja bisa diterjemahkan sebagai 'Allah yang maha tinggi' (yang umum dalam terjemahan alkitab LAI), tetapi terjemahan paling tepat 'êl 'êlyōn' adalah 'pencipta atau pemilik alam semesta yang memerintah seperti bapa memerintah anaknya.' Jika sepakat dengan pengertian ini, maka figur ini akan identik dengan titel 'ēl lainnya yang disebut sebagai pencipta dan pemilik anak-anak Allah dan manusia - seperti 'ēl dalam naskah Ugarit. ${ }^{84}$

Polemik dalam menentukan apakah El dan Yahweh merupakan ilah identik atau tidak menurut penulis dapat diselesaikan dengan menentukan apakah yang dimaksud teks Ulangan 32:8-9 perihal "anak-anak Israel" dalam terjemahan Masoret, atau "malaikat Tuhan" dalam LXX, serta "anak-anak El” dalam translasi Qumran.

${ }^{83}$ Ibid., Pritchard, ANET: SFIRE 1 A, Political Document, 659.

${ }^{84}$ Habel. Yahweh Maker of Heaven and Earth: A Study in Tradition Criticism. JBL. 91 (1972), 321-337 
Untuk itu, penulis melihat penting untuk melihat ke belakang mengenai ide sidang ilahi dengan struktur panteonnya yang merupakan warna utama agama di Ugarit, Kanaan dan Israel yang telah dibahas penulis di Bab II penelitian ini.

\subsubsection{Sidang Ilahi EI}

Sistem dan cara beragama orang Israel tidak akan mungkin terlepas dari kosep sidang ilahi yang dianut orang Kanaan yang terdapat dalam catatan Ugarit di mana El digambarkan sebagai ilah tertinggi yang memerintah para Allah dan manusia. Ada beberapa istilah umum di Ugarit untuk menyebut perkumpulan sidang ilahi ini: ada istilah phr ilm, $d t$ dan $d r$. Phr dapat di artikan sebagai $p h r$ 'ilm (perkumpulan para Allah), Mphrt/phr (Perkumpulan anak-anak El), bn 'ilm (anak-anak Allah), phr m'd (perkumpulan dalam sidang), dan $p h r$ $\mathrm{kkbm}$ (perkumpulan bintang-bintang). Istilah $p h r$ di atas sering ditujukan untuk satu kelompok khusus yang terikat dengan dewa tertentu seperti "perkumpulan Ba'al" di atas, $p h r$ parallel dengan anak-anak El ( $b n$ ' $i l$ ) dan perkumpulan para bintang ( $p h r \mathrm{kkbm})$ dan lingkaran penghuni surga $(d r d t \check{s} \mathrm{~mm})$ yang pada akhirnya menunjukkan bahwa setiap perkumpulan tersebut membentuk bagian yang disebut sidang ilahi. Menurut Mark S. Smith, mphrt/phr yang terekam dalam CAT 1.40.25.42, menunjuk kepada sidang ilahi di mana El berdiri di tengah-tangah anak-anaknya, dan bukan suatu kelompok sidang ilahi yang terpisah dari El. ${ }^{86}$

Istilah lain yang juga sering dipakai untuk menunjuk kepada "suatu dewan ilahi" adalah $d t$ dan $d r$. Istilah $d t$ biasanya dipakai untuk menunjuk kepada kumpulan $\mathrm{El}$, atau secara literer

${ }^{85}$ Dennis, Pardee, Ritual and Cult (SBL 10; Leiden: Brill, 2002), 4449

86 Mark S. Smith. The Origin of Biblical Monotheism: Israel's Polytheistic Background and the Ugaritic Texts, (New York: Oxford University Press, 2001), 41-57 
menunjuk kepada "lingkaran El" yang sedang berpesta. Sedangkan terma $d r$ merupakan terma umum yang biasa ditujukan kepada istilah sidang ilahi El. Penjelasan yang lebih lengkap dapat terlihat dari konstruksi yang dibuat Clifford ${ }^{87}$ ketika ia menempatkan $d r$ 'il sebagai perkumpulan El yang diteruskan dengan $d r$ bn ' $i l$ yang merupakan perkumpulan anak-anak El. Selanjutnya mereka akan disebut sebagai 'perkumpulan penghuni surga' dengan istilah $d r d t \check{s} m m$, dan posisi terakhir dikuasai oleh $d r$ 'il wphr $b^{\prime} l$ yang merupakan perkumpulan sidang jemaat Ba'al.

Para anggota sidang ilahi ini tinggal atau berdiam di suatu gunung kudus di mana El menjadi kepala panteonnya. Gunung tempat mereka berdiam dikenal dengan nama gunung Li dan terekam dalam teks Ugarit CAT 1.2.I.14, 20, yang memuat frasa $p h r m^{\prime} d$ dan $r$ 'll yang dapat berarti 'tempat pertemuan para anggota sidang ilahi. ${ }^{88}$ Dalam "pertemuan" atau "jemaah dalam perkumpulan" ( $p h r m$ 'd $)$ itu, terlihat El duduk sebagai dewa tertinggi ditemani oleh Asherah yang dikelilingi oleh anak-anaknya yang disebut bene ilm.

Selain frasa $b n$ 'il yang menunjuk pada 'anak-anak el', kita juga melihat ada frasa 'ilm: Allah-Allah, bn 'ilm, anak-anak Allah, dan bn 'atrt, anak-anak Atirat. Dalam argument Mark S. Smith yang sudah dibahas di atas, terlihat sistem panteon Ugarit tersebut memiliki model/ bentuk keluarga Patriakal. ${ }^{89}$ Dua tingkat pertama (El, Asherah, Ba'al) merupakan anggota penting dari sistem pemerintahan, sedangkan dua tingkat selanjutnya (Moth, Yam, Tannin, Anat), adalah para staf yang khusus melayani figur-figur level di atas mereka.

${ }^{87}$ Richard J Clifford, The Cosmic Mountain in Canaan and the Old Testament. HSM 4. (Cambridge, MA: Harvard University Press, 1972), 7-8; 97

${ }^{88}$ Ibid.

${ }^{89}$ Ibid., Smith,.The Origins of Biblikal Monotheism, 54-66 
Lebih spesifik lagi, Smith membagi peta ilahi Ugarit antara dewa-dewi baik dengan dewa-dewi jahat. Dalam level horizontal, para dewa baik (El-Asherah dan Baal) masuk dalam kategori "baik/ dekat," sedangkan para dewa jahat/ monster (Moth, Yam, Tannim, Anat) berada di wilayah "jahat/ pinggiran" yang merupakan musuh dari para dewa-dewi baik. Hal ini juga bisa diartikan sebagai perbedaan antara dewa pemberi keuntungan dengan dewa pencipta kerugian yang umumnya dilambangkan dengan monster (tannim dan lewiatan).

Inilah yang disebut sebagai konsep Sidang Ilahi (divine council) yang oleh Smith merupakan bentukan struktur antropomorfisme monster-monster yang dibagi dalam dua level: level dekat dan jauh (pinggiran), seperti yang sudah disebutkan di atas - di mana level dekat adalah dewa-dewi yang tergolong jinak; dewa-dewa baik yang memiliki kultus untuk disembah. Pada level jauh adalah mereka-mereka yang disebut sebagai monster-monster seperti Mot dan Yam. Pernyataan Smith ini diperkuat dengan argumentasinya terhadap Mazmur 82 dan Ulangan 32, sebagai berikut: ${ }^{90}$

The author of Psalm 82 deposes the older theology, as Israel's deity is called to assume a new role as judge of all the world. Yet at the same time, Psalm 82, like Deut 32:8-9, preserves the outlines of the older theology it is rejecting. From the perspective of this older theology, Yahweh did not belong to the top tier of the pantheon. Instead, in early Israel the god of Israel apparently belonged to the second tier of the pantheon; he was not the presider god, but one of his sons. Accordingly, what is at work is not a loss of the second tier of a pantheon headed by Yahweh. Instead, the collapse of the first and second tiers in the early Israelite pantheon likely was causedby an identification of El, the head of this pantheon, with Yahweh, a

${ }^{90}$ Ibid., Smith,.The Origins of Biblikal Monotheism, 49 
member of the second tier. (Penulis Mazmur 82 memberikan kesaksian hadirnya teologi kuno tentang ilah Israel yang memiliki tugas atau memegang satu peran sebagai hakim atas dunia. Namun pada saat bersamaan, Mazmur 82 dan Ulangan 32 yang menyimpan/ mempertahankan garis besar dari teologi kuno tersebut melakukan penolakan atas tradisi tersebut. Dari perspektif teologi yang lebih tua ini, Yahweh tidak berasal dari tingkat tertinggi sistem panteon. Sebaliknya, di Israel kuno Allah Israel kelihatannya berada pada posisi level kedua dari sistem panteon; Yahweh bukanlah presiden dari para ilah, melainkan salah dari anaknya (el). Sehingga apa yang terlihat kemudian bukan lenyapnya para ilah tingkat dua yang dipimpin oleh Yahweh, melainkan runtuhnya para ilah level satu dan dua dalam sistem panteon Israel yang disebabkan 'bersatunya atau identifikasi' yang terjadi antara El sebagai kepada panteon dengan Yahweh yang sebelumnya berada pada posisi kedua).

Smith percaya runtuhnya level pertama dan kedua dari struktur sidang ini terjadi pada sekitar abad ke 8 SM; ketika Asherah yang sebelumnya merupakan pasangan EL, menjadi pasangan Yahweh; semua ini hanya dapat terjadi apabila kedua ilah tersebut telah mengalami identifikasi satu dengan lainnya pada saat itu. Tetapi, sebelum masa tersebut tiba, Yahweh dan El tetap merupakan ilah berbeda dalam sistem politeistik Israel. Pemisahan kedua ilah - ayah dan anak tersebut pada akhirnya merupakan elemen penting untuk memahami Sidang Ilahi dan degradasinya dalam sejarah Israel. Reduksi sistem Panteon yang terjadi menurut Smith murni didorong motivasi dari pergerakan Monoteisme dari komunitas pascaPembuangan yang ingin menempatkan Yahweh sebagai ilah utama tanpa saingan. Berdasarkan analisis di atas, Smith menetapkan narasi dalam Masmur 82 dan Ulangan 32 sebagai gambaran El Allah maha tinggi yang memerintah atas seluruh anggota sidang ilahinya dalam 
posisi sebagai Allah pengasuh (parental god), sedangkanYahweh hanyalah salah satu dari anak-anak El yang melakukan tuduhan terhadap ilah lain karena perbuatan tidak adil mereka di bumi.

Dalam konteks Perjanjian Lama, konsep sidang ilahi ini dapat terlihat dalam teks seperti Mazmur 29 yang bersamaan dengan frasa bene elim yang parallel dengan istilah Kanaan banu ili (anakanak el) dan banu qudsu (anak-anak qudsu) dalam literatur Ugarit yang ditemukan. ${ }^{91}$ Dalam Mazmur 82, kita melihat ada istilah tertentu yang yang terkait dengan konsep sidang ilahi $\bar{e} d \bar{a} t$ atau ădat dengan istilah Kanaan. Frasa "Sidang Ilahi" yang muncul dalam Mazmur 82:1 paralel dengan frasa phr 'ilm (CAT: 29.11.7; Ug. V9.19), dan kalimat 'Sidang Elohim" dalam bentuk phr bn 'ilm (CAT: 4.III.14), juga kalimat "Perkumpulan Anak-Anak 'Ēl" dalam pola mphrt bn 'ilm (CAT: 30:3; 32.1.3.9.17.26.35) dalam inskripsi Ugarit. ${ }^{92}$ Bukan hanya istilah $\bar{e} d \bar{a} t$ atau ădat saja yang muncul, kita juga menemukan dalam Dalam Amos 8:14, terdapat istilah dôr (perhimpunan) Yang dalam teks Kanaan disebut `il/dr bn 'il. Istilah ini dipergunakan sebagai petunjuk umum untuk sebutan "sidang ilahi "êl" dalam mitologi Kanaan (CAT:30.2; 32.1.2.9.17.25-26.34; 34.7). Yesaya menggunakan istilah mô'éd untuk menunjuk kepada "gunung Pertemuan," yang dalam teks Ugarit (CAT:2.1) disebut har- mô'éd, sedangkan "kemah pertemuan 'ēl disebut 'óhel mô 'éd. ${ }^{93}$

Berdasarkan argumetasi di atas, kita melihat frasa "Sidang Ilahi" dalam literatur Kanaan dengan Israel sangat identik satu dengan lainnya. Sistem agama Israel tidak mungkin dapat terlepas dari sistem agama Kanaan di mana mereka berdiam. Model agama Ugarit dengan sistem Sidang Ilahi pada hakekatnya bernuansa politeis. Warna politeis Ugarit ini ternyata terekam di banyak bagian dalam

${ }^{91}$ Ibid., Mullen, The Divine Council in Canaanite and Early Hebrew Literature, 117-119

92 Ibid., Cross, Canaanite Myth and Hebrew Epic, 157-160

${ }^{93}$ Ibid., Matthews, Social World of Ancient Israel, 121-123 
literatur Ibrani. Memperhatikan semua ini, maka sangat sukar apabila ide "Monoteisme" yang dikumandangkan kaum konservatif terhadap sistem agama Israel; khususnya pada era bait Allah pertama, masih dipertahankan.

Menurut penulis, raja Salomo, sangat memahami perihal sistem Panteon Ugarit - yang juga menjadi sistem Panteon Israel ini. Fakta menunjukkan Salomo memelihara banyak allah lain selain Yahweh dalam bait suci di Yerusalem yang kemudian dihancurkan Yosia sekitar 300-350 tahun kemudian. Hadirnya multi ilah di bait suci Yerusalem; selain sebagai bentuk polites Israel saat itu - juga merupakan implikasi dari bentuk agama Israel yang masih menggunakan model sidang ilahi dengan El atau Yahweh yang berperan sebagai kepala Panteon. Perihal penulis Tawarik yang menetapkan Salomo sebagai penemu atau pengembang agama Yahwistik - menurut penulis harus dibaca dari dua perspektif. Pertama, Daud - yang kemudian diteruskan Salomo dapat dikatakan sebagai pioneer-pioner sentralisasi Yahweh dalam sistem agama Israel. Kedua, namun demikian, upaya sentralisasi ini tidak sertamerta menghilangkan model penyembahan politeistik Israel saat itu. Bukankah Yosia harus membuang banyak allah lain yang beroperasi dalam bait suci Yerusalem dalam reformasinya?

Akan tetapi, kembali Michael S. Heisser tidak sepakat dengan gambaran panteon di atas. Menurut Heisser, sistem agama Israel mengenal model sidang ilahi seperti yang dimiliki Kanaan, tetapi yang menjadi kepala panteonnya adalah Yahweh dan bukan El seperti di Ugarit. Untuk itu, kita tidak boleh membaca teks Ulangan 32:8-9 dan Mazmur 82:1 sebagai disusun dalam kerangka retoris dalam konteks strategi redaksional ketika menghadapi evolusi keagamaan di Israel di mana ada semacam asumsi bahwa Yahweh pada suatu waktu tertentu dalam sejarah pernah berada di bawah El 
yang Maha Tinggi (elyon), namun saat ini ia memegang kontrol, seperti yang dianut Mark S. Smith (Politeisme kepada Monoteisme). ${ }^{94}$

Menurut penulis argumentasi Heisser ini kembali tidak tepat karena para peneliti ANET seperti Smith, Ackerman dan Handy tidak pernah memulai penelitian mereka; dalam hal ini Mazmur 82 dan Ulangan 32 dengan asumsi sistem agama Israel berevolusi dari bentuk Politeisme menuju Monoteisme seperti yang diusung Albrecht Alt. Melainkan, argumen yang dibangun berdasarkan pemahaman bahwa teks yang ada memiliki atau memperlihatkan bentuk kosmologi yang politeistik pada dirinya sendiri. Smith tidak pernah membangun suatu presuposisi dalam upaya legalisasi eksegesis yang dikerjakan. Sebaliknya mereka melakukan eksegesis dan bermuara pada suatu simpulan. Persoalan kemudian ketika konklusi menjadi presuposisi, merupakan persoalan lain, sebab seperti inilah dunia eksegesis.

Menurut Heisser, istilah אלהים atau אלים dalam teks Qumran berhubungan dengan anggota Sidang Ilahi. Dalam pemikiran Heisser, apabila konsep Sidang Ilahi ini menghilang saat pembuangan Israel, bagaimana menjelaskan kemunculannya kembali? Menurut Heisser, istilah אלים אלהים tetap dalam ide semula pada era sebelum pembuangan. Akan tetapi para sarjana ANET seperti Smith mengubah dua istilah tersebut menjadi sebatas "pembawa pesan" dalam struktur Panteon Smith dan Handy, mereka menjadi ilah pembawa berita. Sehingga dapat disimpulkan istilah אלים atau dalam konteks Qumran akan menjadi malaikat - seperti yang muncul dalam terjemahan LXX dengan frasa "malaikat tuhan," dan bukan Allah itu sesungguhnya; yaitu אלים yang tadinya identik dengan

94 Ibid., Heisser, The Divine Council, 75 (Dalam hal ini Smith berargumen penulis Mazmur 82 membuang model teologi asli ketika mereka harus menyusun warna Allah Israel dalam konteks dunia setelah pembuangan atau setelah pembuangan. Namun pada saat bersamaan, Mazmur 82 dan Ulangan 32:8-9 tetap menyimpan garis besar dari model teologi lama yang telah dibuang tersebut. Dari perspektif teologi lama ini, Yahweh bukan merupakan bagian atau berada di bawah kepala Panteon Kanaan) 
Yahweh - saat ini menjadi semacam pembawa pesan semata. Pertanyaan Heisser adalah: mengapa istilah yang sama dapat berbeda arti pada era sebelum pembuangan dan setelah pembuangan? Padahal konsep keilahian yang muncul di Qumran jelas-jelas menggambarkan אלים atapat tumpang tindih dengan istilah מלאכים אלהים yang samasama berdiri dalam satu level sebagai "ilah" dan bukan "pembawa pesan." Untuk itu, terjemahan LXX atas Ulangan 32:8-9 mengenai frasa "Malaikat Tuhan" patut dipertanyakan kebenarannya. ${ }^{95}$

Argumentasi Heisser di atas menurut penulis tidak memperlihatkan bukti yang disusun oleh LXX. Terjemahan LXX yang mendahului terjemahan Qumran secara rutin menterjemahkan istilah Elohim dan seluruh variannya sebagai bene ha Elohim, atau sebagai angeloi. Ulangan 4:19 dan 17:3 (LXX) menterjemahkan


menghapus ide istilah tersebut berhubungan dengan allah tertentu. Dalam Mazmur 97:7 dikatakan "biarlah segala Allah menyembahnya" (MT dan LAI), sedangkan LXX menterjemahkan teks ini sebagai: "biarlah segala malaikat menyembahnya." Dengan ini terlihat teks Qumran yang lebih muda telah melakukan pergeseran tafsiran. Namun demikian, kita tetap dapat melihat bahwa Qumran tetap melihat frasa "bene elim" sebagai satu istilah teknis yang dapat diterjemahkan sebagai "Malaikat Tuhan" juga (11Q10 30:5; 4Q180). Sedangkan elim (Allah-Allah) dapat digunakan bergantian dengan istilah "yang kudus," "malaikat," atau "pengawas." Dengan ini penulis melihat terjemahan MT dan LAI yang menetapkan "malaikat tuhan" menjadi "anak-anak Israel" dalam Ulangan 32:8, sebagai tidak tepat.

Kembali Heisser berargumen bahwa titel Elyon dalam ayat 8 haruslah merujuk pada El dan bukan pada Yahweh seperti dalam ayat 9. Beberapa alasan dikemukan: pertama, bentuk literari dari Ulangan 32 memberikan argumentasi terhadap segala ide yang menyatakan bahwa Yahweh bukanlah sang Maha Tinggi dalam pasal

95 Ibid., Heisser, The Divine Council, 76-79 
ini. Sebab, telah lama diketahui bahwa analisis kritik bentuk atas Ulangan 32 telah mendemonstrasikan dominasi dari suatu bentuk hukum. Narasi tuntutan dalam Ulangan 32:15-18 merupakan isu penentangan dari umat pilihan Yahweh, yaitu Israel yang telah meninggalkan batu karangnya yang benar (32:5-6) dan kembali kepada penyembahan Allah lain yang kuasanya berada di bawah kuasa Yahweh. Untuk itu sang hakim - Yahweh sendiri dalam teks Ulagan 32 ini - kemudian digambarkan menjatuhkan hukuman (32:19-29). ${ }^{96}$

Menurut penulis, tidak ada dalam teks Ulangan 32 kita menemukan kalimat bahwa Allah lain berada di bawah kuasa Yahweh. Ayat 43 memang mengindikasikan para Allah dipanggil dihadapan Yahweh, namun menurut penulis hal ini tidak berarti mereka berada di bawah otoritas Yahweh. Gambaran ini semacam pemenuhan atau janji dari Yahweh bahwa ia selalu menjaga umatnya sekaligus menyerang musuh-musuh mereka. Sehingga saat ia melakukan semua ini, terbukti ia lebih kuat dari allah lainnya. Untuk itu, mereka akan tunduk dihadapanNya. Akan tetapi, para allah yang tunduk dihadapan Yahweh tidak dapat dikatakan mereka berada di bawah otoritas Yahweh karena tidak ada indikasi di manapun para Allah berada di bawah kuasa Yahweh sebelum era penggabungan atau berfusinya El dan Yahweh terjadi; dalam bahasa Handy, Yahweh telah naik ke posisi utamanya.

Yahweh juga digambarkan bertindak sebagai hakim di sini, namun kita seharusnya tidak melihat Ia menjadi hakim atas para allah dalam sidang ilahi mereka semenjak ia anggota dari sidang ilahi itu sendiri. Yahweh menjadi hakim kelihatannya diarahkan kepada umatnya; umat yang kepadanya telah dibagikan oleh El. Jadi, gambaran ini memperlihatkan sang ilah yang sedang bertindak atas domain atau wilayah yang menjadi kekuasaanya; dalam hal ini Israel adalah wilayah kekuasaannya. Yahweh lebih digambarkan terus menerus bertempur untuk membela umatnya; untuk itu ia tidak

${ }^{96}$ Ibid., Heisser, The Divine Council, 83-85 
mungkin duduk disinggasana yang biasanya ditempati El - Allah yang tidak mau terlibat dalam kesulitan dunia dan manusia. Dengan ini, usaha Heisser untuk menempatkan Yahweh sebagai hakim dalam konteks Ulangan 32 dalam upaya menempatkan posisinya sebagai Allah Maha Tinggi (elyon) dalam Ulangan 32:8-9, tidak mungkin berhasil. Narasi Deuteronomi merupakan naskah kuno yang sudah hadir sebelum kitab Deuteronomi dibuat, yang kemudian digabungkan dalam bagian ini. Pertanyaan dan pendekatan yang dilakukan untuk memahami teks ini seharusnya tidak bersifat pembacaan sinkronik, melainkan diakronik. Kita mungkin tidak boleh memutuskan suatu teks dibaca dalam terang sinkronik padahal mampu dilakukan konfirmasi dari sudut diakronis.

Dalam bagian penutup analisis ini, penulis tertarik membuat suatu rekonstruksi dari Ulangan 32:8-9 sebagai upaya memperhatikan hadirnya evolusi bagian perbagian dari teks tersebut sehingga kita dapat membuat suatu hipotesis yang kuat, sebagai

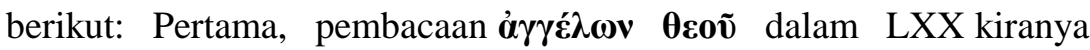


yang diambil, maka sangat mudah menduga bahwa Vorlage (patron) dari MT bermaksud mengubah teks politeistik menjadi monoteistik dengan memasukkan konsonan ישר sebelum אל, sehingga menciptakan pembacaan בני ישראל. Penulis MT sepertinya berargumentasi istilah dalam 4QDeut ${ }^{j}$ dimengerti sebagai tulisan yang memiliki kesamaan arti dengan terminologi "Tuhan" pada era mereka.

Rekonstruksi Jan Joosten, ${ }^{97}$ menurut penulis dapat membantu dalam memahami teks Ulangan ini.

97 Jan Joosten, "A note on the text of Deuteronomy xxxii 8," VT 57 (2007), 548-555. Selain itu, lihat juga: Michael S. Heiser, "Deuteronomy 32:8 and The Sons of God," BibSac 158 (2001) 51-74; Randall Garr, In His Own Image and Likeness. Humanity, Divinity, and Monotheism(Leiden: Brill, 2003), 223-224. 


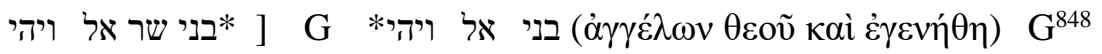

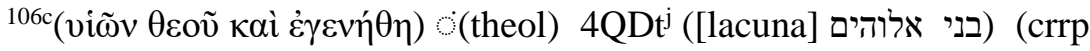
of והיםto ויהי M SP $\alpha^{\prime} \theta^{\prime} \sigma^{\prime} \mathrm{V} \mathrm{S}\left(\mathrm{T}^{\mathrm{J}}\right) \mathrm{T}^{\mathrm{ONF}}$ (theol). Dalam rekonstruksi ini, frasa שָר אהל 'Tanduk atau Kerbau El diperpendek dalam satu alur transmisi dalam hubungannya dengan pemahaman teologis di kemudian hari yang dipandang lebih dapat dimengerti

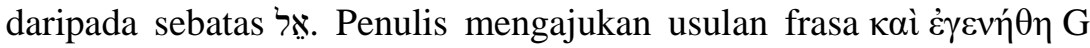
sebagai refleksi ויהי dengan melakukan analogi penerjemahan standar dengan pembacaan 4QDeut ${ }^{j}$ yang kemudian dapat membawa hasil pada kemungkinan kesalahan mekanis. Terminologi כי yang dimuat dalam M SP V S T pada akhirnya terlihat menjadi elemen kedua yang merupakan revisi dari elemen ישראל, sama seperti yang tercantum dalam M SP V S T. Terjemahan istilah כישר menjadi "lihatlah," di satu sisi merupakan cara praktis yang kurang tepat. Sebab sangat meragukan jika כי memiliki maksud dan arti seperti di atas. Teks yang mengalami koreksi dan terekam dalam MT akan menjadi sebagai berikut:

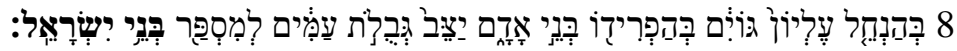

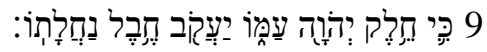

Ketika Sang Maha Tinggi memberikan bangsa-bangsa sebagai milik pusaka,

Ketika ia membagi umat manusia,

Dia meletakkan perbatasan dari umat itu,

Menurut jumlah/angka anak-anak Israel,

Sebab bagian Tuhan adalah umatNya.

Yakub merupakan bagian pusakanya.

Sedangkan teks yang belum mengalami revisi adalah:

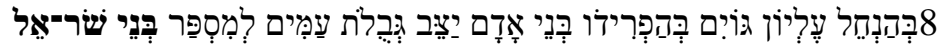




Ketika Elyon memberikan bangsa-bangsa sebagai milik pusaka, Ketika ia membagi umat Manusia,

Ia mengatur batasan umatnya

Menurut jumlah dari anak-anak Tanduk El,

Dan bagian Yahweh adalah umatnya.

Yakub merupakan bagian dari pusakanya.

Hasil rekonstruksi ini memperlihatkan pembacaan "anakanak Israel" yang dimiliki MT dan diikuti oleh Heisser seta beberapa terjemahan resmi lainnya menjadi sulit dimengerti dalam konteks LXX dan Qumran. Masoret memasukkan ide "anak-anak Israel" terlihat sebagai upaya menghilangkan nuansa politeistik dalam teks ini sekaligus memberikan muatan teologis yang terbebas dari warna politeistik yang kemungkinan masih ada dan berkembang saat penulisan teks ini.

\subsubsection{Analisis Mazmur 82:1}

Mazmur 82 sering dihubungkan dengan Ulangan 32 terutama dalam latar-belakang mitis yang dimiliki keduanya. Perhatian utama pada pasal ini terletak pada istilah Elohim yang kemudian menimbulkan beragam interpretasi di kemudian hari; terutama frasa Elohim yang muncul di ayat 1 dan 8 . Jika memperhatikan translasi literalnya saja, maka kita cenderung akan membaca "Allah berdiri di tengah sidang Allah." Terjemahan ini menuntun kita pada pemahaman bahwa ada "dua Allah" berbeda yang hadir dalam sidang ini; di mana Yahweh memainkan peran sebagai penuntut dan El duduk sebagai Allah tertinggi atau sebagai kepala panteon. Pemikiran ini berkembang di antara para ahli yang percaya bahwa agama Israel tetap dalam warna Politeistik, Henoteistik atau Monolatri sampai dengan abad ke $8 \mathrm{SM}$; yang mungkin ditulis oleh 
redaktur Yahwis dan mengalami redaksi pada erah Elohis. ${ }^{98}$ Para pakar yang memiliki argumen El dan Yahweh sebagai ilah berbeda, akan menggunakan latar-belakang mitologi Ugarit dan Kanaan sebagai starting point penafsiran mereka.

Namun demikian, tidak dengan Wellhausen, Albrecht Alt, Heisser dan De Moor; mereka cenderung menetapkan teks Ulangan 32 dan Mazmur 82; sebagai teks yang tidak membedakan antara El dan Yahweh. Bahkan Mazmur 82:1 diterjemahkan Michael S. Heisser sebagai berikut:

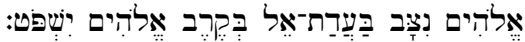

God ('lhym) stands in the divine assembly; in the midst of the gods (lhym) he passes judgment. (Allah berdiri dalam sidang ilahinya, di tengah para Allah ia memberikan penghakiman). Terjemahan yang dilakukan Heisser serupa dengan translasi ESV, RSV dan LAI. Terjemahan Heisser di atas menurut penulis tidak tepat karena dalam tradisi Qumran, istilah Elohim dan el sangat dibedakan. Elohim umumnya diterjemahkan atau diidentifikasi sebagai gambaran malaikat, sedangkan el lebih sering merujuk pada Allah Israel. Jadi, terjemahan yang tepat berdasarkan tradisi Qumran adalah: "Elohim berdiri di tengah sidang ilahi El, di tengah para Allah ia memegang penghakiman." Terjemahan KJV dan Ampilfied kelihatannya mengekor translasi Qumran dan LXX. Jadi, bukan Elohim berdiri di tengah sidang ilahi seperti yang dipikirkan Heisser sebagai maksud ayat ini, melainkan Ia berdiri di tengah sidang ilahi El. El yang memimpin sidang ini dan Yahweh sebagai salah satu anak bene ilum berdiri di antara para ilah lainnya dalam ruang sidang ilahi El.

Penulis melihat mayoritas sarjana ANET menetapkan istilah Elohim yang muncul dalam kalimat pembuka teks sebagai

98 Willa Boesak, "Exegesis and Proclamation, Psalm 82: God Amids the Gods." Journal of Theology fo Southern Africa, 64 (1988), 64-68. 
Yahweh dan yang lainnya sebagai Allah El. Misalnya argumentasi Simon Parker yang menetapkan kemunculan Elohim dalam ayat 1a dan 8 merujuk pada Yahweh. Yahweh dalam sidang tersebut sebatas sebagai salah satu dari anggota Sidang Ilahi lainnya yang berada di bawah kekuasaan El atau Elyon. Menurut Parker, kata kerja נצב (berdiri) dalam pasal 82:1 merujuk atau mengindikasikan Yahweh sebagi "penuntut" dan bukan "pemegang kuasa" dalam konteks hukum. ${ }^{99}$ Berdasarkan argumentasi ini, El akan digambarkan sebagai kepala Panteon yang memimpin seluruh anggota sidang ilahinya. Sedangkan Yahweh merupakan salah satu dari anaknya (bene elim) yang melancarkan tuntutan terhadap ketidakadilan yang dilakukan ilah lainnya. Peran Yahweh pada akhirnya terlihat sebagai penuntut dalam sidang ilahi tersebut sebab sang hakim adalah El itu sendiri. Fakta bahwa Yahweh 'berdiri' dan tidak duduk dalam sidang ilahi tersebut seharusnya merupakan kepastian bahwa Yahweh bukanlah pemimpin tertinggi dalam sidang itu dengan kalima-kalimat sebagai berikut: "Berapa lama lagi kamu menghakimi dengan lalim dan memihak kepada orang fasik? Berilah keadilan kepada orang yang lemah dan kepada anak yatim, belalah hak orang sengsara dan orang yang kekurangan! Luputkanlah orang yang lemah dan yang miskin, lepaskanlah mereka dari tangan orang fasik!" Mereka tidak tahu dan tidak mengerti apa-apa, dalam kegelapan mereka berjalan; goyanglah segala dasar bumi (Mazmur 82:2-5 LAI). Tuntutan Yahweh ini kemudian diikuti dengan kalimat legal hukum yang datang dari Yahweh: Aku sendiri telah berfirman (Aku berkata: "Kamu adalah Allah, dan anak-anak Yang Mahatinggi (Anak-anak Elyon) kamu sekalian. -- Namun seperti manusia kamu akan mati dan seperti salah seorang pembesar kamu akan tewas" (LAI - huruf tebal translasi penulis). Konsep ini pada akhirnya sejajar dengan siklus Panteon Ugarit dan Kanaan di mana El selalu berdiri sebagai kepala Panteon

${ }^{99}$ Simon B. Parker, The Beginning of the Reign of God - Psalm 82 as Myth and Liturgy. Revue Biblique 102 (1995), 533-534. 
menjalankan perannya sebagai raja segala raja. Untuk itu, penilaian atau keberatan Heisser mengenai El yang menjadi kepala Panteon dan menjalankan penghakiman dalam Mazmur 82:1 sebagai tidak relevan dengan konteks yang ada; apalagi melihat dengan latar belakang konsep atau ide sidang ilahi Israel yang sangat mirip dengan apa yang dimiliki dunia Kanaan.

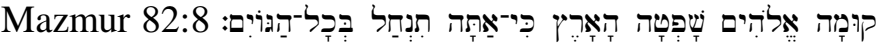

oleh LAI diterjemahkan menjadi: "Bangunlah ya Allah, hakimilah bumi, sebab Engkaulah yang memiliki segala bangsa." Menurut Heisser persoalan dengan pemahaman El dan Yahweh sebagai ilah berbeda akan muncul dalam ayat ini di mana Yahweh diminta untuk 'berdiri' dan bertindak untuk mengontrol bangsa-bangsa. Jika mengikut kata kerja קוּמָה, (bangkit berdiri) dalam teks ini, seharusnya kita melihat bahwa Yahweh sedang duduk - dia duduk sebagai hakim dan bukan El. El bagi Heisser tidak pernah muncul dalam pasal inidi mana ayat 1 dari pasal ini merupakan bentuk paralel dengan ayat 8 . 100

Bagi Smith dan Parker, apabila Yahweh yang duduk sebagai kepala Panteon, maka timbul pertanyaan: jika Yahweh yang diminta berdiri untuk mengambil tindakan seperti yang tertera pada ayat 8 , maka siapa yang berdiri sebagai penuntut? ${ }^{101}$ Menurut Parker, pertanyaan yang harus diajukan seharusnya adalah apakah tindakan ini dilakukan oleh dewa yang berkuasa penuh, atau tindakan dari anggota

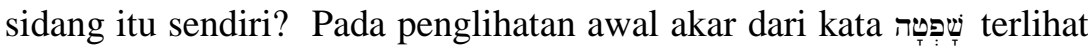
memiliki beberapa varian arti; yang mana munculnya kata tersebut dalam Mazmur ini memiliki arti berbeda satu dengan lainnya. Dalam ayat 1 , gambaran yang muncul adalah perkataan pembukaan yang di dalamnya termasuk tengkingan bagi anggota sidang untuk tidak menyimpangkan keadilan dengan melakukan tindakan pilih kasih.

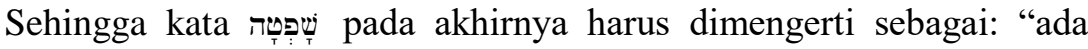

100 Ibid., Heisser, The Divine Council, 80

101 Ibid., Smith, The Origin, 48 
allah yang berdiri di tengah Sidang Ilahi El sedang menuntut atau meminta petanggungjawaban.” Istilah ש̛̣ tidak pernah memberikan implikasi bahwa sang pembicara merupakan anggota yang berkuasa penuh dalam sidang ilahi tersebut, selain ia digambarkan sedang menuduh para Allah yang hadir saat itu. ${ }^{102}$

Dari telaah Parker di atas, dapat disimpulkan bahwa Yahweh yang berdiri sebagai sang penuntut - pastilah ia berbeda dengan El yang duduk sebagai Allah maha tinggi. Padanan situasi ini dapat kita temukan dalam teks Ayub 1:6 di mana "anak-anak Allah" hadir dalam sidang ilahi di hadapan Yahweh untuk berdiskusi mengenai Ayub. Atau dalam teks 1 Raja-Raja 22:19-21 ketika Yahweh digambarkan duduk di tengah anggota bala tentara surganya, serta dalam teks Zakaria 3:1-7 di mana ada penglihatan imam Yosua sedang dituntut dan dituduh oleh para malaikat yang berdiri dihadapan Yahweh. Dengan ini penulis kembali menegaskan bahwa Mazmur 82:1-4 mengindikasikan Yahweh bukanlah Allah yang menguasai sidang ilahi, melainkan ia sebatas anggota sidang ilahi di antara anggota sidang ilahi lainnya.

Apabila melihat model mitis sidang ilahi El dan Ba'al di Kanaan, maka kita pasti akan menemukan bahwa El yang menduduki posisi tertinggi dalam Panteon tidak pernah melancarkan tuduhan atau tuntutan apapun. Kelihatannya hanya Ba'al dan Yahweh yang sering terlihat mengajukan protes. Protes yang mereka lancarkan; terutama Ba'al pada akhirnya terimplementasi pada pembunuhan antar dewa dan berakhir pada perebutan singgasana dari dewa yang terbunuh. Motif sidang yang terus berulang ini sangat jelas dalam Mazmur yang sedang penulis bahas. Yahweh saja yang memulai pertempuran dengan dewa-dewa lainnya dan pada akhirnya ia akan mengambil semua warisan mereka menjadi miliknya sendiri.

Yahweh dan El dalam pasal ini tidak dapat dikatakan sebagai ilah berbeda hanya berdasarkan pada berita penulisan narasi

102 Ibid., Parker, The Beginning of the Reign of God, 533-534 
ini entah berasal dari era Pembuangan atau pasca Pembuangan. Kedua ilah ini berbeda lebih dikarenakan status keduanya dalam sistem Panteon yang berbeda; seperti yang digambarkan oleh Smith dan Handy di mana Yahweh digambarkan muncul sebagai ilah Junior dalam Panteon El Elyon, kemudian Yahweh diberitakan mendapat bagian bangsa-bangsa dari El, namun status baru tersebut tidak membuat ia menjadi lebih berkuasa dari El. Selanjutnya digambarkan kedua ilah tersebut melebur satu dengan lainnya sampai berakhir dengan munculnya Monoteisme di Israel. Langkah pertama yang dimulai dari kemunculan Yahweh sampai bergabungnya kedua ilah tersebut terjadi pada Israel sebelum era Pembuangan. Sedangkan poin di mana Israel masuk dalam era Monoteisme, terjadi ketika mereka akan masuk dalam masa Pembuangan.

Menurut penulis, cerita mitis dalam Mazmur ini merupakan refleksi dari material kuno yang mengalami semacam rekonfigurasi. Memberikan penekanan pada sisi teologis dengan ide mana yang "diilhamkan" dan mana yang tidak, akan membawa kita pada model konsistensi teologi sistematik yang tidak dikenal oleh orang Israel kuno. Lebih jauh penulis melihat peneliti teks-teks seperti di atas seharusnya tidak berorientasi pada usaha melakukan atau menjaga kesesuaian/konsistensi teologis dengan melawankannya pada sumber-sumber ekstra-biblika.

Perbedaan antara El dan Yahweh sangat besar. El sering digambarkan sebagai pencipta alam semesta dan pencipta para Allah. Sedangkan Yahweh lebih sering digambarkan sebagai pencipta Israel. El juga digambarkan sebagai pencipta manusia secara umum (Kejadian 1). Tetapi tidak bagi Yahweh. Kata qanah yang diterjemahkan mencipta, dapat berarti membeli, mengambil, mendapatkan, memiliki, juga menjadikan (Kejadian 2). Jadi istilah ini tidak mesti diterjemahkan sebagai "menciptakan." Itulah sebabnya istilah ini berdiri sejajar dengan istilah asah (membuat, mendandani) yang bisa juga diindikasikan sebagai mencipta. Akan tetapi, poin 
utama di sini adalah qanah yang muncul dalam Kejadian 2 tidak pernah digambarkan sebagai epitet; melainkan kata kerja yang menggambarkan tindakan Yahweh. Apalagi jika kita memikirkan ide "penciptaan atau menciptakan" dalam Dunia Timur Tengah Kuno yang tidak berhubungan sama sekali dengan konsep creation ex nihillo. Konsep dalam Kejadian ini merujuk pada membentuk, mendandani, atau membangun sesuatu dari material yang sudah jadi. Jadi, Yahweh mendandani Israel semenjak era Abraham. Secara literer ia menciptakan mereka dari kandungan Sarah.

Bagi penulis, El dan Yahweh tidak pernah menjadi ilah identik sejak permulaan sejarah Israel. El merupakan Allah yang disembah oleh para Patriak dan orang-orang Kanaan. Sedangkan Yahweh; ia merupakan Allah yang berasal dari bagian selatan Kanaan; Edom, Midian atau Seir, yang bertemu dengan Israel; dalam hal ini Musa. Yahweh kemudian di bawah bersama umat keluaran Mesir menuju tanah Kanaan. Di Kanaan kedua kultus ini berjalan bersamasama di mana sering terjadi pertemuan dan perpisahan di antara mereka. El menjadi Allah favorit di Israel, sedangkan wangsa Yehuda diperkirakan lebih menyukai Yahweh. Pernyataan ini masih dapat diargumentasikan mengingat inskripsi Kuntillet Ajrud dan Khirb el Qom jelas-jelas menyatakan ada Yahweh yang disembah di Samaria (Shomron dan Teman) yang berlokasi di wilayah Israel.

\subsection{Simpulan}

Teori dan rekonstruksi Allah Israel yang pernah dibuat oleh Wellhasussen yang membedakan antara El dan Yahweh, kemudian dimodifikasi oleh Albrecht Alt dengan tetap melakukan dikotomi antara Yahweh dengan El Kanaan - serta dikembangkan oleh F.M. Cross dengan ide Yahweh dan El merupakan ilah identik pada mulanya - berpisah - dan bersatu kembali, patut mendapat pertimbangan dan pujian dari para ahli yang berkecimpung dalam teks-teks Dunia Timur Tengah Kuno; termasuk di dalamnya Israel dan 
teks Perjanjian Lamanya. Namun demikian, kita melihat ada perbedaan jelas antara Yahweh dengan El dalam catatan Keluaran 3 dan 6, Ulangan 32 dan Mazmur 82 yang telah dibahas penulis di atas dan dalam bab-bab sebelumnya penelitian ini. Keluaran 3 dan 6 jelas menyebut atau merujuk kepada 'Allah para leluhur' yang dikenal dengan 'Allah bapaku/bapamu.' Bahkan dalam Ulangan 6, Yahweh jelas-jelas berkata bahwa namaKu belum dikenal oleh para leluhur Israel. El merupakan Allah para Patriak dan bukan Yahweh. Jika mengikuti argumentasi Albrecht Alt, maka El yang disembah Patriak berbeda dengan yang disembah orang Kanaan. Namun ketika Israel berada di Kanaan, Israel digambarkan tidak mampu menghindari El yang disembah Kanaan sehingga terjadi sinkretisme dengan Yahweh yang dibawa dari Midian.

Walaupun F.M. Cross menyimpulkan bahwa Yahweh pada mulanya nama Kultik dari El, namun argumentasi Mark S. Smith dan Handy dengan meyakinkan membatalkan argumentasi Cross tersebut dengan susunan Panteon Kanaan dan Israel di mana Yahweh dan El terlibat di dalamnya sebagai Allah level satu (El) dan level dua (Yahweh) dalam konsep sidang ilahi Israel. Kedua ilah ini kemudian berfusi pada waktu kemudian di Israel karena berbagai alasan; salah satunya adalah gerakan reformasi keagamaan yang terjadi pada awal pembuangan Yehuda ke Babilonia. Yahweh digambarkan banyak mengadopsi epitet yang dimiliki El sebelumnya seperti: El Allah maha kuasa dan maha tinggi yang kemudian disematkan kepada Yahweh sehingga ia dikenal sebagai Tuhan Maha Kuasa dan Maha Tinggi.

Hipotesis dan konstruksi yang dibuat oleh Albrecht Alt, F.M. Cross dan Heisser, menurut penulis sangat baik, akan tetapi penulis tidak dapat menyetujui argumentasi dan hipotesis mereka ketika harus menempatkan El dan Yahweh sebagai ilah identik dalam dunia agama Israel. El jelas-jelas dibuktikan dalam banyak inskripsi kuno; terutama dalam inskripsi Ugarit sebagai kepala Panteon di Ugarit dan Kanaan. Para bapa leluhur yang hidup terikat dalam dunia 
Timur Tengah Kuno saat itu tidak mungkin dapat melepaskan diri dari struktur sosial dan agama yang ada saat itu. Banyak bukti ekstrabiblikal dan biblikal yang jelas-jelas menyatakan bahwa para bapa leluhur menyembah El yang mereka sebut sebagai El Elohe Abraham, Pahad Ishak dan Abir Yakub. Belum lagi jika kita melihat epitet atau lokasi yang berhubungan dengan Allah tertentu yang dikenal dengan El-Olam, El-Shadday, El-Roi dan El-Olam.

Sedangkan Yahweh yang bertemu dengan Musa di Padang Gurun Sinai, jelas merupakan Allah yang disembah di Padang Gurun Sinai; di dalamnya termasuk penduduk daerah Midian dan Suku Keni yang merupakan keturunan Kain yang dipercaya sebagai penyembah Yahweh. Catatan Hakim-Hakim 5, Ulangan 32 dan Habakuk pasal 3 bahkan menggambarkan Yahweh yang datang dari Paran, Seir, Edom dan Bashan. Jumlah lokasi berbeda dan era berbeda yang menceritakan kemunculan Yahweh dalam sejarah Israel ini memberikan bukti bahwa Yahweh merupakan ilah independen yang terpisah dari El. Bahkan bukan saja Yahweh terpisah dari El, multi warna dan ragam Yahweh yang muncul dalam catatan biblikal di atas memberikan kepastian bahwa pernah ada dalam sejarah Israel (bahkan non Israel) agama multi Yahwistik. Hal ini semakin diperkuat ketika ditemukannya inskripsi dari Kuntillet Ajrud dan Khirbet el Qom yang menyebut Yahweh dari Shomron dan Teman. Yahweh yang muncul dalam ke dua inskripsi ektra-biblikal di atas ternyata hadir dengan Asherah yang selama ini dipercaya sebagai pasangan $\mathrm{El}$ dalam panteon Kanaan.

Kehadiran Yahweh dengan Asherah dalam inskripsi ini dibahas William Dever dengan sangat baik. Menurut Dever, Yahweh dalam praktek dan kepercayaan Israel, memiliki pasangan, yaitu Asherah. Bukti-bukti atas klaim ini dapat terlihat dalam apa yang disebut 'sinkretisme Yahweh dengan Asherah' dalam berita kitab Ibrani. Bukti lain yang tersedia adalah ikonografi dan kultus YahwehAsherah yang terbilang tidak sedikit di Israel dan Yehuda pada era 
monarki. Data-data yang mendukung pandangan ini menurut Dever dapat terlihat dalam teks-teks Ibrani yang seharusnya dibaca bukan dari sudut kepentingan kaum elit penulis Perjanjian Lama, melainkan dibaca dari poin praktek tindakan keagamaan saat itu. Asherah dalam teks-teks Ibrani dikenal dengan Aserot yang berulang-ulang muncul dalam teks namun tidak terlihat dalam terjemahan King James. Bukti lain yang menguatkan argumen Dever adalah penemuan di Khirbet el Qom dan Kuntllet Ajrud yang terang menderang menyebut Yahweh berpasangan dengan Asherah. Walaupun terjadi perbedaan terjemahan antara Dever dengan ahli lain seperti John Day, namun keduanya sepakat bahwa Yahweh memiliki pasangan yang disebut Asherah, yang beroperasi bersama-sama di Israel; bahkan beroperasi ratusan tahun setelah era Daud yang dibuktikan kehadirannya di bait Allah Yerusalem ketika terjadi reformasi yang digalang oleh raja Yosia. ${ }^{103}$

Politeisme merupakan realitas Israel. Perkembangan Monoteisme bagi Dever, muncul sangat akhir dalam era Israel. Monoteisme Yahwistik merupakan bentuk idealistik para penguasa Yerusalem yang ortodoks dan nasionalis yang bekerja serta melakukan serangkaian editing terhadap kitab Ibrani. Namun dari semua ini, bukanlah realitas sesungguhnya Israel. Sebagai contoh Dever menggunakan "korban persembahan Israel" sebagai ilustrasi. Segala bentuk korban persembahan yang dilakukan orang Israel dan mendapat pembenaran dalam kitab Ibrani menurut Dever, memiliki persamaan dengan apa yang dilakukan orang Kanaan. Dalam buktibukti arkeologi yang ditemukan, baik orang Israel maupun orang Kanaan sama-sama merayakan sukkoth, pesach, dan shavu'ot. Sinkretisme bagi Dever bukan karena satu pihak telah melakukan apa yang seharusnya dilarang. Sinkretisme dalam konteks Israel kuno adalah mereka dan orang Kanaan berbagi kultur dan sistem agama

${ }^{103}$ William Dever, Did God Have a Wife? Archaeology And Folk Religion in Ancient Israel, (William. B. Eerdmans, Co, 2005), 176-245 
yang sama. Sinkretisme yang merupakan produk modern sudah pasti tidak dipahami oleh orang Israel saat itu - tidak mungkin terminologi sinkretis dikenakan kepada masyarakat yang tidak memiliki kosa-kata dan makna sinkretis. ${ }^{104}$

Pada akhirnya kita melihat bentuk penyembahan para Patriak digambarkan sangat sederhana. Mereka hanya mengikuti contoh dari para leluhurnya Habel dan Nuh yang memberikan korban persembahan di tempat yang telah ditetapkan Allah - di altar yang dibangun seperti di Hebron, Betel, Moria, Beersheba, Sikem dan Betel. Model penyembahan mereka berbeda dengan apa yang dimiliki Israel dengan Allah Yahweh dikemudian hari. Agama para Patriak berorientasi pada agama keluarga, klan yang berdasarkan dunia semi nomaden. Dengan ini, gambaran Kejadian terhadap agama mereka lebih nyata, dan bukan produk imajinasi era terkemudian. Mereka kelihatan Monolatri non eksklusif dengan masing-masing Allah sesembahan yang dinyatakan berkuasa atas klan ataupun keluarga sebab Allah mereka sering dinyatakan memiliki hubungan khusus dengan mispaha seperti yang tergambar dalam Kejadian 15 dan 17 yang menunjukkan hadirnya ikatan perjanjian - di mana janji dan perlindungan ilahi serta penyertaan dan pemenuhan akan kebutuhan mereka dipenuhi sampai kepada anak cucunya.

Wenham bahkan mencatat ada empat perbedaan penting agama Patriak dengan agama Israel dikemudian hari. Pertama, penggunaan El lebih sering daripada Yahweh untuk menyatakan pewahyuan ilahi. Allah selalu menyatakan dirinya sebagai El tanpa embel-embel self designation yang verbal khas Yahweh yang eksklusif, kudus dan teguh pada satu Allah seperti dalam gambaran Yahweh Keluaran. Para Patriak walaupun penyembah setia El, namun mereka dikatakan menikmati berhubungan dengan para penyembah ilah lain - dalam bahasa sederhana - mereka membangun semacam kesenangan oikumenis yang tentu saja berbeda dengan model

${ }^{104}$ Ibid., Dever, Did God Have a Wife? 252-317 
eksklusif Yahweh. Kedua, absennya figur Ba'al dalam tradisi agama patriak merupakan poin unik yang dimiliki mereka. ketiga, tidak ada figur yang menjadi media dalam tradisi agama ini. Allah berbicara kepada mereka langsung melalui visi dan mimpi dan tidak melalui nabi atau imam. Untuk menyikapi suara Allah tersebut, mereka membangun altar dan memberikan korban persembahan tanpa bantuan lembaga keimamatan. Keempat, Yerusalem belum menjadi tempat kultus utama dalam tradisi agama Patriak. Sikhem, Betel, Mamre, atau Beersheba, berulangkali disebut sebagai tempat dimana Patriak datang bertemu dengan Allah dalam pemberian korban persembahan.

Israel kuno hidup dan berbagi banyak hal dengan bangsa sekitarnya. Siapapun Allah yang mereka klaim sebagai Allah mereka, tidak menafikan sang Allah juga diklaim oleh bangsa lain di sekitar mereka. Yahweh menjadi Allah utama Israel melalui mulut Musa ketika ia bertemu dengan Yahweh di gunung Sinai. Di bagian awal tulisan ini Yahweh dinyatakan datang dari Sinai, Seir, Edom dan Shomron. Semua lokasi tersebut berada di Selatan wilayah Palestina. Walaupun ada indikasi nama Yahweh terdeteksi di Ugarit, namun belum bisa dipastikan oleh para ahli apakah Yahweh yang dimaksud identik dengan Yahweh dalam berita Musa.

Di Kanaan, ada kemungkinan Yahweh juga telah dikenal oleh bangsa-bangsa yang berdiam disekitar Kanaan. Perihal mereka pernah menyatakan Yahweh sebagai Allah mereka sebelum Israel menggunakannya, tidak menjadi perhatian dalam penelitian ini. Yang menjadi perhatian utama adalah apakah Yahweh identik dengan El; termasuk El Kanaan dan Ugarit? El dinyatakan sebagai Allah yang berdiam dalam dunia Mesopotamia. Dalam naskah Ugarit, ia dinyatakan sebagai kepala Panteon; sekaligus yang menciptakan manusia dan para Allah yang tergambar dalam sidang ilahi yang dipimpinnya

Memang banyak epitet El yang menempel atas Yahweh. Namun, ekspresi ini tidak serta-merta menyimpulkan kedua ilah ini 
satu atau identik seperti yang diklaim Michael S. Heiser dan Cross. EL dan Yahweh merupakan dua ilah berbeda yang pernah menjadi sesembahan Israel kuno. Keduanya kemudian melebur, berfusi, atau bergabung di Israel, lebih dikarenakan adanya pergerakan dan kepentingan tertentu dari para elit Israel dan Yehuda, yang terkenal dengan gerakan 'Yahweh Alone' atau dalam bahasa Mark S. Smith, munculnya Yahweh sebagai Allah utama Israel dalam konteks Monoteisme merupakan proses differentiation sebagai upaya membedakan dan melepaskan semua nuansa Politeistik Kanaan dalam diri Yahwisme yang sebelumnya tidak menjadi masalah dalam sistem agama Israel. 


\section{Bab III}

\section{Perkembangan El Dan Yahweh Di Monarki Israel}

Mengikuti hipotesis Mark S.Smith, penulis menetapkan asal-mula Allah Israel adalah El. Argumen ini berdasarkan dua analisis penting yang dilakukan Smith. Pertama, nama Israel tidak mengandung ide Yahwistik, melainkan El. Fakta ini menunjukkan El merupakan kepala Panteon dari sistem agama Israel; persis seperti yang dimiliki Ugarit dan Kanaan. Kedua, Kejadian 49:24-25 mempresentasikan serial El yang terpisah dari penyebutan Yahweh dalam pasal 18. Demikian pula Ulangan 32:8-9, menempatkan Yahweh sebagai yang tidak memegang peran dalam peranan yang dimainkan oleh anak-anak El, yang disebut elyon.

Setelah El memainkan perannya sebagai Allah Israel; terhitung sejak era Patriak, Yahweh kemudian muncul - sekaligus menjadi salah satu Allah utama Israel; terutama sejak figur Musa muncul dalam peristiwa Keluaran. El dan Yahweh menjadi AllahAllah utama yang disembah Israel di Kanaan bersama dengan ilah lainnya seperti Ba'al, Anat dan Asherah. Tampaknya pada awal-awal kerajaan, tradisi Israel mengidentikkan El dengan Yahweh atau memandang kedua ilah tersebut serupa. Bahkan tradisi Priestly seperti yang tergambar dalam Keluaran 6:2-3, mengidentikkan El Shaday dengan Yahweh, seperti diklaim F.M. Cross. Lebih jauh Smith melihat ilah-ilah utama Israel pada periode hakim-hakim tidak sebanyak yang dimiliki masyarakat Ugarit. ${ }^{105}$ Apabila merujuk kepada Kejadian 49:25-26, Israel mungkin hanya mengenal empat ilah utama dan terpisah yaitu: El, Yahweh, Asherah dan Ba'al. Situasi ini segera berubah pada periode awal Monarki; Yahweh dan El sudah dinyatakan sebagai ilah identik pada sekitar abad ke 10 SM,

${ }^{105}$ Ibid, Smith, The Early History of God, 22-23 
sedangkan Asherah mulai dilihat sebagai figur utama dalam kultus tertentu yang berpasangan dengan El. Asherah kemudian diberitakan berpasangan dengan Yahweh saat El mulai kehilangan pamornya. Smith menduga Israel kemungkinan besar lebih politeistik pada era para Hakim, akan tetapi, figur dan kultus Yahweh pada saat bersamaan terus meningkat menuju ide Yahwistik monolatri dalam beberapa periode berjalan. P.D. Miller, melihat hal ini dapat terjadi diseBabkan mulai muncul ide Allah yang tidak bisa digambarkan sebagai hasil dari pengaruh konsep sepuluh hukum dalam tradisi religius Israel, serta polemik terhadap elohim aherim, "other gods" (Kel.20:3) dan elohim hadassim, "Allah-Allah baru” (Hak. 5:8; Maz. 44:21), dilanjutkan dengan penolakan terhadap Allah-Allah lain (U1.32:39; 1 Sam. 2:2). ${ }^{106}$ Selain itu, terjadinya sentralisasi kultus penyembahan terhadap El dan Yahweh; terutama Yahweh yang disertai dengan munculnya tulisan-tulisan yang dianggap berotoritas di era Monarki - dipandang menjadi pendorong berkembangnya monolatri di Israel.

\subsection{Agama Israel Monarki (Saul): Keberlanjutan Dan Inovasi}

Raja Saul memainkan peran besar dalam menetapkan, menjalankan dan melanjutkan model penyembahan El dan Yahweh di Kanaan; terutama Yahweh pada era Monarki. Saul yang berasal dari tanah Benyamin; tepatnya di wilayah Gibea (1 Sam. 10:26), yang bisa juga disebut dengan Gibeon - terkenal memiliki bamot yang menjadi pusat sesembahan suku Gibea (Benjamin) saat itu (1 Raj. 3:4). Gambaran ini menempatkan Saul dan keluarganya sebagai penyembah ilah-ilah yang beroperasi di Gibea atau Gibeon, yang kemungkinan besar El dan Yahweh. Hubungan antara Saul dan Gibea di atas

106 P.D. Miller, "Israelite Religion" in The Hebrew Bible and its Modern Interpreters, ed. D.A. Knight and G.M Tucker (Philadelphia: Fortress; Decatur, GA: Scholars, 1985), 212 
kelihatannya berdasarkan hubungan etnik walaupun ada gambaran raja Israel itu pernah menyerang Gibeon dalam 2 Samuel 21.

\subsubsection{Yahweh Di Kerajaan Utara}

Walaupun kekuasaan Saul tidak melingkupi seluruh suku Israel; di mana Yehuda dan wilayah Galilea tidak pernah menjadi bagian kerajaannya, namun pengaruhnya atas bagian wilayah Israel yang dikuasai sangat besar. Saul dikenal sebagai Raja yang tidak pernah lepas dari peperangan; khususnya dengan orang Filistin. Untuk itu, kemungkinan besar Yahweh yang disembah dan diproklamirkan adalah Yahweh yang identik dengan peperangan. Berdasarkan asumsi ini, Saul dipercaya memiliki pengaruh besar dalam perkembangan agama Israel Monarki; apalagi dalam statusnya sebagai pendiri Israel, ia tentunya mendirikan dasar keagamaan bagi Israel saat itu.

Apabila memperhatikan situasi Israel pada era kepemimpinan Saul yang penuh peperangan; utamanya dengan Filistin, maka kemungkinan besar model beragama yang dianut kerajaan saat itu adalah agama militer yang menempatkan Yahweh sebagai Allah peperangan seperti yang sudah disinggung penulis di atas. Agama militer cenderung menjadi agama resmi kerajaan di mana umat Yahweh menjadi anggota tetap sekaligus pemimpin tertinggi dari pasukan ini. Semua warga negara yang merupakan keturunan Yahweh (1 Sam. 26:19 dst) dan diurapi Yahweh 9 (1 Sam. $24: 7,11)$, pada akhirnya memiliki musuh yang juga disebut sebagai musuh Yahweh ((1 Sam. 30:26 dst). Berdasarkan argumentasi ini penulis melihat doktrin keagamaan yang dibangun berlandaskan Yahweh sebagai Allah nasional, benar-benar memiliki karakter militer yang militan. Model ini kelihatannya merupakan suatu bentuk "keberlanjutan" dari model beragama yang pernah lekat dalam Musa saat peristiwa Keluaran. Allah Yahweh saat itu dipandang sebagai Allah peperangan yang berparade dari selatan untuk membebaskan 
Israel dari tangan Firaun. Ia datang membawa pembebasan bagi Israel dari Mesir kemudian membawa mereka selamat masuk ke Kanaan seperti yang tergambar dalam nyanyian Debora.

Akan tetapi, penulis melihat Allah peperangan atau militer yang dianut Saul telah mengalami modifikasi siknifikan dari konsep yang dianut Musa. Yahweh tidak lagi sebatas dipandang sebagai Allah pembebas seperti yang dimengerti Musa ketika membawa Israel keluar dari Mesir. Ideologi Yahweh era Saul adalah Allah pahlawan gagah perkasa yang memberikan kemenangan kepada Israel dimanapun mereka berperang. Yahweh juga dipahami tidak sebatas konsep dan nilai-nilai abstrak yang tergambar dalam tiang api dan tiang awan, melainkan pada era Saul, Yahweh termanifestasikan dalam institusi kerajaan - sekaligus dalam setiap praktek penyembahan yang ada di Israel sebagai bentuk realitas spiritual yang dioperasikan dalam kultus-kultus ibadah kerajaan di seluruh Israel. Konsep Yahweh abstrak pada era Musa berubah menjadi konkret pada era Saul yang dibuktikan dengan bertumbuh-kembangnya kota-kota para imam beserta segala atribut yang menggambarkan atau menjadi simbol Yahweh; terutama yang tergambar dalam kultus ibadah Saul (Israel) di Nob yang juga dikenal sebagai kota para imam dalam 1 Samuel 22 di mana Yahweh dipercaya menjadi Allah utama pada era dinasti Saul. Hal ini bukan berarti Yahweh menjadi satu-satunya Allah sesembahan Israel; melainkan ia menjadi salah satu Allah utama saat itu - termasuk bagi masyarakat yang menyembah allah lain selain Yahweh.

Informasi mengenai Yahweh dalam periode ini cukup sulit ditemukan dalam catatan Perjanjian Lama; khususnya mengenai Yahweh yang beroperasi di kerajaan Utara, maka, penulis menggunakan informasi atau catatan ekstra-biblikal yang terbukti pernah merekam kehadiran Yahweh di Israel pada era Saul yang ditemukan dalam inskripsi Moab pada era raja Mesha yang 
menggambarkan kesuksesan Moab melawan raja Ahas dari Israel. ${ }^{107}$ Dalam inskripsi Moab ini, Yahweh menjadi Allah nasional Israel yang diperkirakan beroperasi pada abad 9 SM. Selain itu, ada inskripsi Kuntillet Ajrud dan Khirbet el Qom yang menjadi rekaman faktual aktivitas Yahweh di Israel; khususnya di Samaria yang memunculkan istilah Yahweh dari Teman dan Yahweh dari Shomron (Samaria).

Yahweh yang menjadi Allah nasional Israel pada era Saul di abad 9 SM seperti yang dijabarkan di atas pada akhirnya membuka ruang argumentasi mengenai Yahweh yang menjadi Allah nasional pada era perpecahan Israel; khususnya di Yehuda. Argumentasi yang muncul adalah Yahweh hanya menjadi Allah nasional ketika Yehuda dengan ibukota Yerusalem menyembah Yahweh sebagai satu-satunya Allah nasional. Sedangkan Israel Utara dengan ibukota Samaria lebih favorit pada Elohim dan ilah lainnya yang mendapat penilaian negatif oleh Yehuda sampai era Deuteronomis. Argumentasi ini menurut penulis dapat dipergunakan, namun memiliki beberapa rambu pembatas. Pertama, Yahweh yang dipandang sebagai Allah nasional Yehuda - sekaligus menjadi satu-satunya Allah seluruh suku Yakub merupakan doktrin yang dibangun oleh para penulis Yehuda sebagai bentuk perlawanan mereka kepada Yerobeam yang mendirikan kultus tandingan di Betel dan Dan. Yehuda tidak pernah menganggap Yerobeam masih melanjutkan model atau pola penyembahan Yahweh di Bethel dan Dan - sekaligus Yerobeam dipandang sebagai perusak model sentralisasi politik dan agama yang sedang dibangun saat itu. Poin kedua dari alasan Yehuda di atas dapat diterima, akan tetapi poin pertama yang menyatakan Yerobeam membangun penyembahan ilah baru di Betel dan Dan tidak dapat dibenarkan. Faktanya apa yang dilakukan oleh Yerobeam saat itu adalah meneruskan apa yang dilakukan oleh nenek moyangnya: yaitu penyembahan kepada Yahweh.

107 KAI 181:14-18 diterjemahkan oleh J. Blau dalam Short Philological Notes on the Inscription of Mesa, Maarau (1979-1980), 143.157 
Kedua, walaupun wilayah Israel (Samaria) menyembah Elohim, Asherah dan Ba'al, mereka juga mengenal penyembahan terhadap Yahweh yang dibuktikan dengan hadirnya beberapa catatan ekstra-biblikal dan warisan Saul atas Israel seperti dijelaskan sebelumnya. Ketiga, Yerobeam seperti Harun, membuat Lembu Emas dan memperkenalkannya kepada Israel sebagai "Allah" yang harus disembah "....inilah alahmu O Israel, yang membawamu keluar dari tanah Mesir." Apakah ini dapat disebut tindakan mendukakan Tuhan? Jika membaca berita Deuteronomis yang merupakan loyalis Yehuda; perbuatan Yerobeam ini adalah pemberontakan terhadap Yahweh; apalagi jika dilihat dari hukum kedua Dekalog. Namun apakah demikian? Kembali kepada kalimat "inilah Allah-Allahmu O Israel, yang menuntunmu keluar dari tanah Mesir" yang terdapat dalam 1 Raja-Raja 12:28 dan Keluaran 32:4. Ketika Salomo membangun Bait Allah, ia berkata 'langit tidak mampu menampung Allah, apalagi bait Allah yang dibuat Manusia." Di sana-sini dalam konteks Tabernakel (Musa dan Daud), tidak pernah ada informasi bahwa Allah duduk dalam Tabernakel, melainkan Ia berdiam di sana. Kemungkinan ditempatkannya Lembu Emas di Betel merupakan alternatif ikonograf bagi Allah Israel; yaitu Yahweh yang bertahta dan terlihat jelas dalam bentuk Lembu Emas, hadir di tengah-tengah umatnya.

Konsep Yahweh atau Elohim yang digambarkan sebagai lembu (atau kerbau) sudah hadir jauh sebelum Yerobeam hadir. Yakub memanggil Allahnya 'Abir Yakub' atau yang kuat dari Yakub - sebagai gambaran tanduk atau kerbau dalam Kejadian 49:24 dan Yes. 1:24. Apakah lembu emas dimaksudkan sebagai representasi Yahweh sendiri atau Yahweh bertahta, tidak terlihat dalam catatan apapun di kitab Raja-Raja, kemungkinan ikonograf Yahweh dalam bentuk Lembu Emas yang dibuat Yerobeam dimaksudkan untuk menempatkan Yahweh sebagai Allah dalam peristiwa Keluaran - juga sebagai alternative Yahweh yang bisa hadir di Betel dan Dan untuk menarik umat Israel agar tidak melakukan perjalanan ziarah ke 
Yerusalem yang secara politik dan ekonomi merugikan Yerusalem. Bagi Yerobeam, Yahweh bisa hadir di mana saja tanpa terikat oleh kultusnya di Yerusalem. Dengan alasan ini, tentu tidak mungkin Yerobeam akan meninggalkan Yahweh - mengganti dengan Allah lain. Untuk itu, kecaman yang dilontarkan Yehuda pada akhirnya lebih bernuansa politik dan ekonomi daripada klaim pelanggaran moral-etika dan tata ibadah kepada Yahweh. Yerobeam tidak pernah melepaskan Yahweh - apalagi berpaling kepada Allah Kanaan lainnya - terutama ia tidak menyembah berhala - yang dibuktikan minusnya kecaman para nabi-nabi Yahweh kepada dirinya.

Bagi Yehezkiel Kauffman, sangat tidak mungkin menghubungkan Lembu Emas Yerobeam dengan penyembahan berhala. ${ }^{108}$ Pemilihan Betel dan Dan sebagai pusat ibadah juga perlu mendapat perhatian kita - khususnya dalam hubungan dengan tradisi Yahwistik. Betel terkenal dalam narasi biblikal sebagai tempat Yakub bertemu dengan Allah - di mana ia membuat 'rumah bagi Allah'disana (Kej.28:10-22). Betel juga terkenal sebagai tempat di mana para hakim mengadakan perang dengan suku Benyamin dalam peristiwa Gibeah. Tabut Allah Perjanjian berada di Betel saat itu, dilayani oleh Pinehas cucu Harun (Hak. 20). Samuel menjadi hakim di Betel, Gilgal dan Mizpah. Sedangkan wilayah Dan, tidak memiliki banyak hubungan dengan Israel.

Beberapa poin teologis untuk mendukung hubungan antara Lembu Emas dengan Yahweh - selain persamaan kedua Lembu Emas dalam narasi berbeda di atas, dapat dinyatakan sebagai berikut: Pertama, Yerobeam membuat lembu emas supaya orang Israel tidak pergi ke Yerusalem memberikan korban persembahan kepada Yahweh. Dalam hal ini Yerobeam tidak memperkenalkan ilah lain selain Yahweh, ia hanya berupaya memberikan lokasi alternatif untuk memberikan persembahan kepada Yahweh selain di Yerusalem.

108 Yehezkiel Kauffman, The Religon of Israel: From its Beginning to the Babylonian Exile, (London: Allen and Unwin, 1961), 270 
Kedua, kritik yang datang menentang kultus Yerobeam haruslah dibaca bahwa kultus yang ia dirikan memang untuk menyembah Yahweh di tempat yang berbeda - telah menjadikan Yerusalem mendapat kultus saingan. Ketiga, seperti terindikasi dalam persamaan kedua kultus di atas, pemberian nama kepada anak Yerobeam sangat berbau Yahwistik: Abijah (Yahweh bapaku). Walaupun ini mungkin mengikuti tradisi - paling tidak ia tetap mempertahankan tradisi Yahwistiknya. Keempat, Elia, Elisa dan Yehu adalah pendukung militan Yahwistik, namun sangat sedikit catatan yang menyatakan mereka mengkritik Lembu Emas Yerobeam. Sebab, jika kedua Lembu Emas yang dipasang di Betel dan Dan merupakan kekejian bagi Tuhan, atau berasal dari Allah bangsa sekitar Israel, pastilah tidak akan lepas dari kutukan Elia-Elisa serta kemarahan Yehu.

Berdasarkan argumentasi di atas, maka klaim Yahweh menjadi Allah nasional di Yehuda terjadi sejak Israel menjadi dua kerajaan akan sulit dipertahankan. Yahweh dipastikan merupakan Allah nasional Yehuda sejak Israel terpisah; sekaligus ia menjadi Allah nasional di Israel-Samaria yang sudah dimulai pada era Saul, disembah bersama-sama dengan El, Asherah dan Ba'al. Yerobeam merupakan pengusung dan pelopor gerakan kembali kepada Yahweh melalui pendirian kultus di Betel dan Dan ketika memisahkan diri dari Yehuda. Yerobeam menurut penulis tidak meninggalkan penyembahan kepada Yahweh, sebaliknya ia berusaha mengikuti jalan nenek moyangnya yang merupakan penyembah Yahweh; terutama Saul yang mendirikan dasar penyembahan Yahweh di Israel.

Sedangkan pemerintahan Daud yang terkenal dengan penyembahan Yahwistiknya, sebatas "keberlanjutan" dari ide Yahweh Allah nasional Israel era Saul, di mana benang merah yang menghubungkan agama nasional kedua raja itu terletak pada "Tabut Allah" yang menjadi tolak ukur kehadiran Yahweh di Israel. Raja Daud mengambil warisan Yahwistik dari raja Saul sekaligus 
melakukan transformasi di dalamnya. Menurut Diana V. Edelmann, hubungan antara agama nasional Saul dan Daud hanya dapat terjadi apabila Saul sebelumnya memilih Yahweh sebagai Allah nasional Israel - yang mana pemilihan ini telah dimulai Saul semenjak ia belum menjadi raja atas Israel ketika Yahweh menjadi Allah klan atau suku Gibeon - ketika ia memberikan nama Yonatan "telah diberikan Yahweh" kepada anaknya sebagai bentuk atau ungkapan ia dan seisi rumahnya merupakan penyembah Yahweh. ${ }^{109}$

\subsubsection{El Di Kerajaan Utara}

Yahweh dan kerajaan Saul merupakan dua entitas yang tidak terpisahkan, namun demikian, penyembahan terhadap El masih berjalan di Kerajaan Utara dengan leluasa. Israel yang sebelumnya berperan sebagai wilayah utama di mana El pernah disembah oleh para Patriak, tentunya masih meninggalkan jejak penyembahan tersebut sampai era Saul dan generasi setelahnya - walaupun Yahweh mulai berkembang dengan pesat di Utara Israel. Dalam hal ini, nabi Hosea yang beroperasi di Israel; yang sangat terkenal akan kecamankecamannya terhadap ilah lain; Ba'al dan termasuk di dalamnya penyembahan terhadap El yang merupakan sisa-sisa tradisi penyembahan Abraham, dapat menjadi bukti nyata model penyembahan kepada El masih beroperasi luas di Israel.

Bagi Hosea, penyembahan terhadap El yang dilakukan Israel telah menyimpangkan mereka dari Yahweh; apalagi jika melihat teks Yosua 24:13-15 yang memberi El label sebagai ilah asing. Menurut G. W. Ahlstrom, penyembahan terhadap El di Israel berasal dari era Yebus yang kemudian meresap dalam Yahwisme di era pendudukan Israel di Kanaan. Penyembahan El ini kemudian berkembang di Israel yang pada akhirnya mendapat kecaman

109 Diana V. Edelmann, the Rise of the Israelite State Under Saul, (Chicago: University of Chicago, 1986), 226-227 
Hosea. ${ }^{110}$ Catatan mengenai kehadiran El di Israel cukup banyak. Dalam Hakim-Hakim 9:46 Allah Shikem El-Berit muncul dengan nama Ba'al Berit dalam berita Deuteronomis (Hak. 8:33, 9:4). Penyetaraan El-Berit dengan Ba'al Berit tampaknya upaya Deuteronomis memberi label penyembahan di Israel sebagai penyembahan berhala. Teks Hosea 8:5 kita ditemukan istilah "lembu" yang ditolak, yang dalam teks Hosea 3:4, dinyatakan sebagai tidak ada raja dan "lembu" (LAI tugu berhala). Jika melihat ke belakang, kita menemukan istilah "lembu" dipergunakan untuk menyebut El dalam "Abir Yakub" El Allah Yakub, maka penulis menggunakan istilah "lembu" di sini sebagai merujuk pada El. Berdasarkan analisis ini, penulis memandang Hosea 8:4-6 merupakan serangan terhadap kultus EL. LAI menterjemahkan teks ini sebagai berikut:

(4) Mereka telah mengangkat raja, tetapi tanpa persetujuan$\mathrm{Ku}$; mereka mengangkat pemuka, tetapi dengan tidak setahu-Ku. Dari emas dan peraknya mereka membuat berhala-berhala bagi dirinya sendiri, sehingga mereka dilenyapkan. (5) Aku menolak anak lembumu, hai Samaria; murka-Ku menyala terhadap mereka! Sampai berapa lama tidak dapat disucikan, (6) orang-orang Israel itu? Itu dibuat oleh tukang, dan itu bukan Allah! Sungguh, akan menjadi serpih anak lembu Samaria itu!

Sedangkan Amplified menterjemahkan:

(4)They set up kings, but not from Me [therefore without My blessing]; they have made princes or removed them [without consulting Me; therefore], I knew and recognized [them] not. With their silver and their gold they made idols for themselves, that they [the silver and the gold] may be destroyed.

${ }^{110}$ G. W. Ahlstrom, Aspect of Syncretism in Israelite Religion, Horae Soedarblomianae V, Lund. (1963), 113-127 
(5) Your calf [idol], O Samaria, is loathsome and I have spurned it. My wrath burns against them. How long will it be before they attain purity?

(6) For this [calf] too is from Israel; a craftsman made it; therefore it is not God. The calf of Samaria shall be broken to shivers and go up in flames.

Dari kedua terjemahan di atas, penulis menempatkan istilah "lembu atau el" sebagai ganti istilah "pemuka" dalam LAI. frasa השֶׁירוּ dalam ayat 4 lebih tepat dibaca sebagai "lembu atau el" yang memiliki persamaan dengan frasa שרי־ yang pernah dibahas penulis dalam Bab IV poin 4.6.2. yang memiliki arti tanduk El. Dalam teks Hosea ini, istilah שִ שר pasti merujuk pada lembu atau El, sehingga cocok dengan pernyataan pada ayat 5 dan 6 Hosea pasal 8. Selanjutnya penulis juga melihat terjemahan LAI dalam ayat 6 tidak tepat ketika berbunyi: "orang-orang Israel itu? Itu dibuat oleh tukang." Kalimat כִ

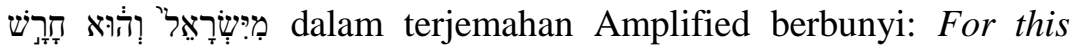
[calf] too is from Israel; a craftsman made it. Ada yang menarik dari

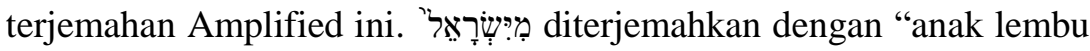
dari Israel." Sedangkan terjemahan LAI menurut penulis sangat tidak

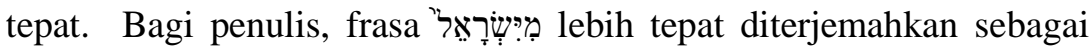

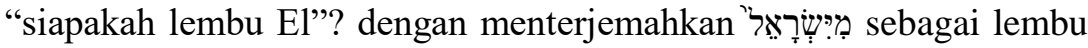
El, maka kita memperoleh kontinuitas sejak ayat 4 yang membicarakan mengenai kehadiran "lembu" atau El yang disembah di Samaria - yang juga dikenal sebagai "Lembu Samaria" yang menurut Hosea merupakan buatan tangan Manusia.

Akan tetapi, serangan Hosea terhadap penyembahan El di Israel, menciptakan ironi dalam pemberian nama kepada anakanaknya. Dalam pemberian nama kepada anak-anaknya. Nama LoRuhamah misalnya, menurut N. Wyatt, nama ini merujuk pada istilah rhmy yang muncul dalam catatan Ugarit (CAT 23.obv.23.28). Dalam CAT 23 ini kita mendapati istilah rhmy merupakan sebutan kepada Asherah yang merupakan pendamping El. Dengan ini Wyatt melihat 
nama Lo-Ruhamah merupakan petunjuk kepada Asherah. ${ }^{111}$ Menurut penulis, argumentasi Wyatt di atas layak mendapat dukungan berdasarkan istilah rhmy yang terdapat dalam CAT 23. Selain itu, pemberian nama Lo-Ruhamah yang berarti 'tidak disayang' - yang jika dihubungkan dengan Asherah, akan menemukan kecocokan dalam konteks yang disasar Hosea; Israel yang tidak disayang karena menyimpang dengan menyembah pada Asherah. Selanjutnya kita juga melihat nama El bahkan muncul secara transparan pada anak pertama Hosea Yizreel; nama yang jelas-jelas memiliki teoforik El. Dari gambaran ini, penulis melihat warna penyembahan terhadap El sebenarnya sangat kuat beroperasi di Israel sampai era Hosea; hal ini sudah dibuktikan dengan pemberian nama kepada anak-anak Hosea dengan elemen EL di dalamnya. Menurut Wyatt, Hosea 7:16 yang merupakan teks yang telah mengalami kerusakan serius sebelum direkonstruksi, sebaiknya diterjemahkan sebagai "mereka telah kembali kepada El sang Maha Tinggi (bukan kepada Ba'al); mereka seperti busur penghianat, "lembu" שָׁריהֶה (bukan pangeran) mereka akan jatuh oleh pedang, para pemimpin mereka dengan kemarahan, karena ini (lembu) merupakan lembu mereka sejak mereka dari Mesir."112 Terjemahan ini tentunya berbeda dengan mayoritas terjemahan yang diakui saat ini, sekaligus menunjuk kepada motif Lembu Emas; yang memperlihatkan pada periode ini El merupakan musuh utama Yahweh. Motif penyembahan kepada lembu yang identik dengan El, terus berjalan dalam era Monarki sampai akhirnya mendapat tantangan (kecaman) dari Hosea; nabi yang pada hakikatnya tetap mengenal dan mempergunakan nama El dalam keluarganya

Penjelasan singkat ini menunjukkan bahwa Hosea memiliki atau mengenal kultus El yang terus beroperasi di Israel

111 N. Wyatt, The relationship of Yahweh and El: a study of two cults and their related mythology. Ph.D Dissertation,University of Glasgow, (1976), 349

112 Ibid., 350 
dalam bentuk atau gambaran lembu, atau anak lembu yang diikat dengan ritus ikatan perjanjian; dalam hal ini ikatan perjanjian seperti EL dan Asherah. Motif perkawinan menjadi dasar dari segala bentuk percabulan dan prostitusi dalam Perjanjian Lama, yang juga menunjuk pada sinkretisme dan penyembahan terhadap ilah lain - dalam hal ini bermuara pada model penyembahan Yahwism yang dimiliki Hosea saat itu. Jika melihat tulisan Hosea dalam kepentingan Yehuda atau bahkan dalam era pembuangan, maka rujukan Hosea kepada El menjadi tidak bermakna dikarenakan konten dari tulisan sang nabi berisi kecaman dan kemarahan terhadap penyembahan terhadap El. Sebaliknya jika melihat tulisan Hosea; seorang nabi yang beroperasi di Utara sejak era raja Uzia sampai Ahaz, maka relevansi material bahasan di atas menemukan tempatnya. Berdasarkan kitab Hosea ini, kita melihat penyembahan kepada El terus berlanjut bersamaan dengan semakin berkembangnya penyembahan terhadap Yahweh. Yahweh terlihat semakin berkuasa, sedangkan El mulai menghilang; paling tidak mendapat label 'ilah asing' dalam kacamata Hosea. Penyembahan terhadap El yang dilambangkan dengan 'lembu atau anak lembu' disetarakan dengan penyembahan 'lembu Samaria' yang merupakan kenajisan bagi Israel. Menempatkan berita Hosea di luar kacamata Deuteronomis akan memberikan gambaran model keagamaan 'sesungguhnya' pada era Monarki. Yahweh memainkan peran penting, demikian Juga El. Hosea yang mempergunakan nama El kepada anaknya; termasuk di dalamnya menggunakan nama Asherah terhadap anak yang tidak disayang, merupakan fakta mengenai penyembahan terhadap El yang masih berlangsung di Israel; bersamaan dengan penyembahan terhadap Yahweh yang semakin sentral. Mempergunakan teori Lowel K. Handy dan Mark S. Smith, penulis melihat Yahweh yang sebelumnya adalah Allah level 2 di bawah pemerintahan El, pada era ini telah berpindah menjadi Allah level satu bersama-sama dengan El. El belum turun tahta (hanya terjadi dalam penulisan Deuteronomis), namun mulai berkurang 
pengaruh dan perannya. Penyembahan terhadap Yahweh di Israel pada awal Monarki yang berjalan dengan penyembahan terhadap $\mathrm{El}-$ sekaligus hadirnya penyembahan terhadap $\mathrm{Ba}$ 'al, Anat dan Asherah, menggambarkan ide 'sinkretisme' dalam kacamata Deuteronomis. Namun itulah fakta yang terjadi. Ba'al pada akhirnya ditolak di gunung Karmel oleh Elia dan Elisha, namun penyembahan terhadap Asherah masih berlanjut. Hal ini dibuktikan tidak ada satupun nabi Asherah yang hadir di gunung Karmel di bunuh oleh Elia. Asherah yang dalam literatur Ugarit selalu berpasangan dengan El tentunya masih memiliki loyalis kuat di Israel; apalagi ketika ia dihubungkan dengan Yahweh. Hal ini menunjukkan El (bersama Asherah) masih memainkan peran siknifikan sebagai Allah utama Israel.

\subsection{Agama Israel Monarki (Daud): Keberlanjutan Dan Inovasi}

Penulis melihat Yahweh yang beroperasi di Samaria tidak pernah eksplisit muncul dalam catatan teks Perjanjian Lama. Melalui inskripsi Kuntillet Ajrud dan Khirbet el Qom, barulah kita mengenal ada Yahweh yang beroperasi di ibukota Israel itu; lengkap dengan penyebutan Asherah sebagai pendampingnya. Namun tidak demikian dengan kultus yang berada di Yerusalem. Setelah Daud menguasai Yebus, tabut Yahweh ia tempatkan di Yerusalem (2 Sam. 5.8-15) dan pada jaman Salomo dikembangkan dengan mendirikan Bait Allah untuk Yahweh (1 Raj. 6). Dari gambaran di atas kita melihat bahwa dinasti Daud dan kultus Yahweh saling terikat satu dengan lainnya. Tahta Daud akan kekal selamanya (walaupun kejahatan Manaseh memaksa Yahweh menolak Yerusalem (2 Raj. 23.26-27) kemudian dikembalikan dalam posisi semula ketika Zedekia memerintah pada beberapa generasi berikutnya. Intinya, kultus Yahweh menjadi kultus utama dan menjadi satu-satunya tempat nama Yahweh didirikan dan disembah. Kultus lain; seperti kultus yang dibangun Yerobeam dan 
Bamot yang bertebaran di seluruh Israel dan Yehuda merupakan parade kejijikan bagi Yahweh; terutama dalam kacamata Deuteronomis.

\subsubsection{Yahweh Sion Dan Yerusalem}

Pada era Monarki, Yerusalem dan Sion identik dengan frasa Gunung Tuhan; frasa yang juga dikenakan kepada "El yang bertahta di atas gunung kudusnya (gunung Li) dan Ba'al yang berdiam di atas gunung Zapon, dalam mitologi Kanaan dalam catatan Ugarit. Mazmur 76.1-2 menguatkan pernyataan di atas "Allah terkenal di Yehuda, nama-Nya masyhur di Israel! Di (Yeru) Salem sudah ada pondok-Nya, dan kediaman-Nya di Sion”! Bahkan dalam Maz. 48.1-2 dikatakan "Besarlah TUHAN dan sangat terpuji di kota Allah kita! Gunung-Nya yang kudus, yang menjulang permai, adalah kegirangan bagi seluruh bumi; gunung Sion itu, jauh di sebelah utara, kota Raja Besar." 113

גדול יהוה ומהלל מאד בעיר אלהינו הר־קדשו...הר־ציון ירכתי צפון קרית מלך רב (Maz.48.1-2)

Sebagian besar versi alkitab (LAI, NASB, Amplified, RSV dan NKJV) hanya berpatokan pada lokasi 'Sapan' yang berada di Utara Israel. Penggunaan istilah Sapan dalam teks BHS nampaknya upaya penulis Mazmur untuk mensejajarkan atribut Yahweh dengan Ba'al yang terkenal dengan gunung Sapan sebagai tempat kediamannya; sekaligus memberikan pujian kepada Yahweh yang telah memilih Yerusalem dan Sion sebagai tempat kediamannya.

Ide dan gambaran Yahweh yang berdiam di Yerusalem dan Sion, pada akhirnya identik dengan kerajaan Daud, yang terus

113 LAI menterjemahkan istilah 'Sapan' dengan 'jauh di Utara, demikian pula Amplified NASB dan KJVmenterjemahkan Sapan dengan 'far North," tetapi BHS masih mempergunakan istilah kuno צפוץ 'Sapan' untuk merujuk pada Zion, dengan tetap menggunakan 'far North' sebagai wilayah di mana Sapan berada. 
bertahan sampai dengan era pasca Pembuangan - era di mana Bait Allah telah dihancurkan - yang tertera dalam dekrit raja Koresh kepada Ezra (Ezra 1.2-4) ketika merujuk kepada Yahweh sebagai 'Tuhan yang berada di Yerusalem' יהוה...האלהם אשר בירושלם Kalimat yang terdapat dalam surat raja Koresh dalam kitab Ezra ini sebenarnya tidak tergambar dengan jelas, selain frasa "Tuhan yang di Yerusalem" (Ezra 7.12-26). Akan tetapi, istilah "elohei samayim” yang merupakan epitet yang biasa dikenakan kepada Yahweh; ternyata muncul tiga kali dalam teks di atas. Munculnya istilah "Allah yang bertahta di surga" dalam teks tersebut menurut penulis cukup menyediakan bukti bahwa kultus Yahweh pernah hadir di Yerusalem dan Sion; bahkan terus bertahan sampai Bait Allah telah dihancurkan di Israel. Pernyataan di atas semakin diperkuat apabila menggunakan argumen Bezalel Porten yang mensejajarkan Yahweh yang berdiam di Yerusalem atau Yahweh yang berdiam di Sion, paralel dengan frasa elohei samayim - Allah yang disembah masyarakat buangan Israel di Elam Mesir.

Kembali kepada Daud yang menempatkan Tabut Allah di Yerusalem - dilanjutkan dengan didirikannya Bait Allah tempat Yahweh berdiam. Dalam peristiwa di atas, kita pada dasarnya tidak pernah melihat dengan jelas nama "Yahweh" hadir atau jelas tertera dalam teks-teks yang berhubungan dengan konteks tersebut, seperti yang penulis pernah jabarkan sebelumnya. ${ }^{114}$ Pengenalan terhadap nama Yahweh di Yerusalem dan Sion datang melalui berita Deuteronomis; bahkan jika dihubungkan dengan Yerusalem sebagai lokasi geografis tempat Yahweh berdiam, nama Yahweh yang eksplisitpun tidak akan ditemukan. Hal ini berbeda jauh dengan nama

114 Walaupun ada ribuan sebutan Yahweh yang dikaitkan dengan kedua kota tersebut; Sion dan Yerusalem, namun tidak berarti nama Yahweh otomatis hadir. Munculnya nama Yahweh yang sangat banyak menurut penulis - serupa dengan pandangan mayoritas ahli Perjanjian Lama yang sepakat menyebutnya sebagai produk akhir Deuteronomis yang menempelkan nama Yahweh kepada Yerusalem dan Sion. 
Yahweh Samaria dan Yahweh Teman yang jelas tertulis dalam inskripsi Kuntillet Ajrud dan Khirbet el Qom. Akan tetapi, berulangkali munculnya istilah elohei samayim yang berhubungan dengan kultus Yerusalem - di mana frasa elohei samayim dipandang sebagai referensi khusus kepada Yahweh - dapat dipastikan bahwa Yahweh dengan kultusnya pernah hadir di Yerusalem dan Sion.

Bagi M. Tzevat, ${ }^{115}$ frasa elohei samayim dapat diterjemahkan sebagai "Yahweh semesta alam" - kalimat yang terdapat dalam catatan Yesaya 47:4 - yang apabila dibaca akan menjadi: "TUHAN semesta alam nama-Nya, Yang Mahakudus, Allah Israel (LAI) (יהוה צבאות שמו). Sedangkan BHS menterjemahkan sebagai: "Yahweh Semesta Alam Nama Nya." Apabila melihat teks Yesaya 8:18 “...TUHAN semesta alam yang diam di gunung Sion”

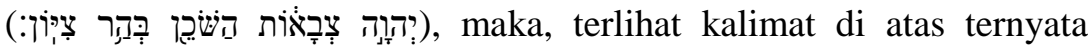
banyak muncul dalam Perjanjian Lama yang dihubungkan dengan Yerusalem bersamaan dengan Shiloh - tempat yang dipercaya sebagai kultus tertua Yahweh di Israel. Istilah elohei samayim kemungkinan

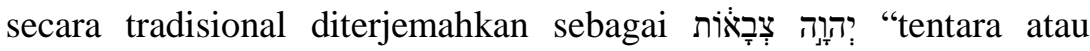


menjadi "tuan rumah" atau "hosts"116 yang merujuk pada tentara surgawai yang bersama-sama dengan Yahweh atau dalam konteks dunia, Israel merupakan bala tentaranya. Namun demikian, Mettinger

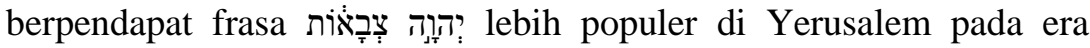
sebelum Pembuangan sampai dengan masa Pembuangan, tetapi tidak pada era klasik pra-Monarki Israel. Hal ini dibuktikan dengan kemunculan frasa tersebut di atas sebanyak kurang lebih 280 kali dalam teks Perjanjian Lama. ${ }^{117}$ Sedangkan J.P. Ross mencatat para nabi klasik Utara; Elia dan Elisa familiar menggunakan istilah יהונה

${ }^{115}$ M. Tsevat, "Studies in the Book of Samuel," HUCA 36, (1965), 55

${ }^{116}$ Penulis akan menggunakan terjemahan "hosts" untuk $f\left(\gg^{10}{ }^{3}{ }^{3 / 4}\right.$ dengan alasan minimnya makna hosts dalam padanan bahasa Indonesia.

${ }^{117}$ T. Menttinger,Yahweh Zebaoth, DDD, (1999), 920 
צִבָאָּר kitab Samuel. ${ }^{118}$ Kesimpulannya, kedua ahli tersebut sepakat

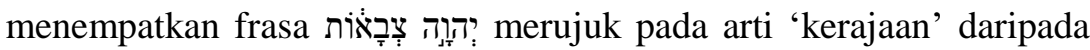
'militer' seperti yang dijelaskan sebelumnya. Bahkan Ross mempergunakan Mazmur 84 - teks yang memberikan puji-pujian kepada Allah yang berdiam di Sion sebagai narasi yang minim bahasa

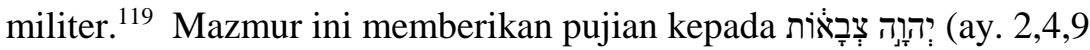


"Tuhan di Sion" (אלהים בציון).

I Raja-Raja 22.19-38, memiliki visi serupa dengan Mazmur di atas ketika menggambarkan Yahweh yang dikelilingi oleh bala tentara surgawinya. Visi dimulai dengan penglihatan Yahweh yang duduk di atas tahta didampingi 2 raja lainnya (istilah "tahta" sebetulnya sudah menujuk kepada suatu sistem pemerintahan lengkap dalam bentuk hirarki). Mikha melaporkan bahwa semua anggota sidang ilahi sedang berkumpul sebagai partisipan di pengadilan tersebut; mereka berdiri sebagai asisten Yahweh mengantisipasi dekrit yang mungkin keluar dariNya. "Mikha menggambarkan Allah yang sedang mengumpulkan nasehat dari anggota sidang ilahinya (1 Raj. 22:20). Dia bertanya bagaimana Ahab harus dihukum karena berperang dengan kesombongannya sendiri. Mereka maju tanpa meminta otorisasi dari nabi Allah. Diskusi berlangsung di antara anggota sidang ilahi tentang bagaimana seharusnya menjalankan kehendak Allah. Mikha menggambarkan perbincangan itu dengan "yang seorang berkata begini, yang lain berkata begitu," namun ia mengerti bahwa mereka sedang membuat suatu rekomendasi penting. ${ }^{120}$

118 J.P., Ross, Jahweh $f\left(»^{1 \circ} \hat{\mathrm{o}}^{3 / 4}\right.$ in Samuel and Psalm, VT 17 (1967), 82.

119 Ibid., 87

${ }^{120}$ Ibid., Mullen, The Divine Council in Canaanite and Early Hebrew Literature, 62 
Penglihatan Mikha ini menunjukkan sistem pemerintahan Yahweh tidak bersifat monistik karena ada partisipan lain di sekitarnya. Penulis kitab percaya bahwa ada semacam dewan di surga yang dapat mempengaruhi keputusan Yahweh. Bagi orang Israel kuno, peristiwa di atas merupakan fakta yang memberikan otoritas terhadap berita yang dibawa Mikha. Sehingga, berita apapun yang disampaikan Mikha, tetap dipercaya sebagai berita Allah. Bahkan model visi seperti Mikha di atas hadir pula dalam teks Yesaya 6.1-3, di mana Yahweh digambarkan hadir dalam baitnya di Yerusalem; lengkap dengan anggota sidang ilahi yang mendampinginya. Bagian ini menunjukkan konsep sidang ilahi dengan ידונה צְבָאלוֹ: yang memiliki motif serupa dengan konteks Mikha. Kalimat pembuka dimulai dengan "aku melihat Tuhan duduk di takhtanya," yang

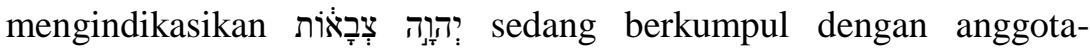
anggota kerajaannya.

בשנת־מות המלך עזיהו ואראה את־אדני ישב על־כסא רם ונשא ושוליו מלאים את־2

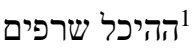

עמדים ממעל לו.... הארץ כבודו כול כול

"Dalam tahun matinya raja Uzia aku melihat Tuhan duduk di atas takhta yang tinggi dan menjulang, dan ujung jubah-Nya memenuhi Bait Suci. Para Serafim berdiri di sebelah atas-Nya, masing-masing mempunyai enam sayap; dua sayap dipakai untuk menutupi muka mereka, dua sayap dipakai untuk menutupi kaki mereka dan dua sayap dipakai untuk melayang-layang. Dan mereka berseru seorang kepada seorang, katanya: "Kudus, kudus, kuduslah TUHAN semesta alam, seluruh bumi penuh kemuliaan-Nya!" (LAI)

Paling tidak hadir 6 persamaan ide antara penglihatan Mikha dengan Yesaya: (1) Kedua-duanya menggambarkan pengalaman mereka sebagai "melihat/ penglihatan kepada Yahweh" 
(2) Dari kedua penglihatan tersebut Yahweh dikatakan duduk di tahtanya (3) ada anggota sidang ilahi yang duduk/ berdiri sekitarnya (4) Yahweh mencari sukarelawan (5) ada sukarelawan yang datang dan (6) sang sukarelawan diberi tugas kemudian pergi. Pembagian ini juga dilakukan oleh John E.C. Kingsbury dalam 5 bagian: (1) Yahweh sebagai raja duduk di tahtanya (2) makhluk surgawi lain berada sekitarnya (3) semua adegan terjadi melalui penglihatan (4) hasil pertemuan diberitakan dalam cerita adegan surgawi dan (5) adegan selalu diasosiasikan dengan pesta agrikultur atau diberi latar belakang peristiwa tertentu.

Sebagai kontras dari cerita Mikha, kembali kita melihat Yesaya digambarkan aktif dengan langsung mengajukan diri menjadi sukarelawan. Cerita serupa dapat ditemukan dalam naskah Ugarit yang menceritakan Ba'al yang mengirim pesan kepada Yam, serta El yang mengirim tugas kepada Anat, dan El mengirim pesan kepada Kothar-wa-Hasis. Dalam konteks di atas, para pembawa pesan diberikan perintah oleh tuannya, kemudian mereka menyampaikan pesan tersebut persis seperti yang diinginkan pengirimnya. Yesaya

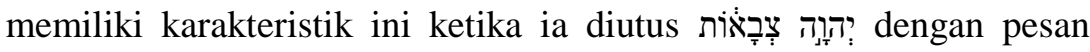
tertentu kemudian dikirim kepada Israel.

Penempatan penglihatan dari Yahweh di Yerusalem dalam teks Yesaya di atas mengindikasikan penulis kitab jelas berupaya menempatkan Bait Allah Yerusalem sebagai poros yang menghubungkan Surga dan Bumi; yang menurut Mettinger dapat dihubungkan dengan teks Amos 1:2 dan Mazmur 11:14 dan 24 sebagai pasal yang menempatkan Sion dan Yerusalem menjadi poros Surga-Bumi, ${ }^{121}$ sekaligus menjadi legitimasi kehadiran Yahweh di Sion yang terekam dalam teks Yoel 3:17, 21 dan Yesaya 8:18, serta Yahweh Yerusalem dalam Mazmur 135:21. Setidaknya ini yang menjadi pemikiran orang Israel sebelum era Pembuangan ketika mereka mempraktekkan tradisi penyembahan Yahweh di Yerusalem

${ }^{121}$ Ibid., Mettinger, Yahweh Zebaoth, 923 
dan Sion. Yahweh dinyatakan pernah tinggal di dua kota suci Israel tersebut. Persoalan mengenai "hanya nama Yahweh" yang berdiam di Yerusalem dalam kacamata Deuteronomi, menurut penulis tidak menghilangkan tradisi dan sejarah Yahweh yang berdiam di Yerusalem dan Sion.

Pertanyaan yang muncul kemudian adalah: sejak kapan tradisi Yahweh di Sion dan Yerusalem muncul? Selain Yahweh muncul dan diperkenalkan Saul - terutama Daud saat menduduki Yerusalem? Menurut penulis argumentasi Stephen L. Cook dapat dijadikan jawaban dari pertanyaan di atas. Selain pada dirinya sendiri di mana Yahweh yang merupakan allah Palestina Selatan diperkirakan telah lama hadir di tengah-tengah orang Kanaan sebelum muncul kelompok suku yang menyebut dirinya Israel, menurut Cook, ${ }^{122}$ bibit kemunculan Yahwisme di Yehuda mulai hadir pada beberapa peristiwa penting Israel sebelumnya; dimulai dari era Daud, kudeta imam Yoyada, reformasi raja Hizkia, reformasi raja Yosia dan pada era finalisasi kitab suci.

Kudeta Yoyada yang berhasil membunuh ratu Atalia dianggap sukses mendesak teologi Sinai masuk dalam masyarakat Yehuda saat itu. Hal ini dapat terlihat dalam teks 2 Raja-Raja 11 yang mengindikasikan adanya pembaruan ikatan perjanjian antara Yahweh dengan Israel; dalam hal ini pembaruan ikatan perjanjian Sinai. Reformasi ini mendaratkan teologi Sinai kepada umat Israel melalui apa yang dikenal dengan "people of the land," suatu kelompok Yehuda yang bergabung dengan beberapa kelompok kecil lainnya untuk bertarung dalam penentuan pemimpin Yehuda; termasuk di dalamnya beberapa nabi Utara seperti Hosea yang mencoba memberikan pengaruh Yahwistik di selatan. ${ }^{123}$ Georg Fohrer

122 Stephen L. Cook, The Roots of Biblical Yahwism, (Boston, Leiden: Brill, 2004), 45-47

${ }^{123}$ Ditcher and Wall, Narrative art Political Rhetoric: The case of Athalliah and Joash, (Sheffield: Sheffield Academic Press, JSOT, 1996), 150 
sebelumnya sudah melihat ada semacam pengaruh Yahwisme yang kuat dari utara (Israel) melalui Hosea kepada reformasi Hizkia ini. Pengaruh utara ini dapat terlihat dalam beberapa nubuatan-nubuatan Hosea dan yang terdapat dalam Mazmur Asaf - seperti Mazmur 50:2 yang mengindikasikan "Tuhan bersinar dari luar Zion." Hizkia menurut Cook menganggap penting perkataan-perkataan Hosea tersebut, sehingga ia memberikan respon positif dalam bentuk advokasi terhadap teologi Sinai yang dibawa kedua nabi tersebut dalam reformasinya. ${ }^{124}$

Ideologi Sinai dengan Yahwehnya yang diusung oleh Hosea dan diletakkan baik di Israel maupun di Yehuda dapat terlihat dalam beberapa teks dalam kitab Hosea seperti dalam pasal 6:7-10 dan 8:1-3, yang mengindikasikan adanya ikatan perjanjian (Sinai?) yang telah dilanggar Israel. Tampaknya Cook melihat istilah "Perjanjian" dalam pasal 8:1 sejajar dengan istilah Tora. Jadi, jika Israel melanggar perjanjian - yang dilambangkan dalam ikatan perkawinan, maka mereka dianggap melanggar Tora yang merupakan instruksi atau aturan utama yang diberikan Tuhan kepada Israel. ${ }^{125}$

Ikatan perjanjian Sinai dapat juga dijejak melalui ide pemberian tanah kepada Israel sebagai milik pusakanya. Dalam Hosea 8:1, wilayah yang dimiliki Israel dipandang sebagai "rumah Yahweh." Di sini Israel wajib mengakui Yahweh sebagai pemberi tanah dan Israel sebagai penerimanya. Konsekuensinya Israel harus mengakui Yahweh sebagi satu-satunya Allah penguasa sekaligus pemberi kesuburan (hidup) bagi Israel. ${ }^{126}$ Tanah harus diupayakan

${ }^{124}$ Ibid., Cook, The Roots of Biblical Yahwism, . 46-49

${ }^{125}$ Pernyataan Cook dalam bagian ini (hal. 73) menurut penulis seperti mengikuti pola Walter Eichordt (lihat Eichordt dalam Theology of the Old Testament-volume 1), yang cenderung menempatkan tora dalam ikatan perjanjian.

${ }^{126}$ Suatu tuntutan yang tidak pernah dapat dipenuhi Israel karena mereka lebih tergoda untuk menyembah dewa-dewi kesuburan KAnaan pada akhirnya. 
dan diusahakan dengan baik; tidak boleh digarap dengan semenamena. Ada akibat buruk menanti apabila Israel memperlakukan tanah pemberian Tuhan dengan semena-mena seBab ikatan perjanjian yang dibuat Yahweh ternyata memiliki sederat pasal penghukuman bagi yang melanggar, seperti tertera dalam Hosea 8:7; 9:12, 16; yang menegaskan kegagalan panen diseBabkan peneymbahan berhala Israel.

Pemberitaan Mikha yang berpusat di Yerusalem, telah melakukan penguatan kepada ide hubungan bilateral dan bersyarat yang merupakan roh teologi Sinai, serta memberikan penekanan pada pelanggaran sosial yang nyata di Yehuda. Pembelaan Mikha terhadap teologi Sinai jelas terlihat dalam teks seperti: Mikha 6:1-8 yang bermuatan "tuntutan/ pengaduan" melawan Israel yang merusak ikatan perjanjian. Sedangkan Mikha 2:2, 9; 3:3. 9-10, mempertontonkan keserakahan para pemimpin Yehuda yang merampok para petani dan mengusir mereka dari tanah perjanjiannya. Dalam Teologi Sinai, tanah milik Tuhan yang diberikan kepada Israel sebagai tanda atau bentuk ikatan perjanjian mereka dengan Tuhan. Jadi tanah tidak boleh diambil atau diberikan kepada siapapun. Jika orang Israel kehilangan tanah, maka mereka secara otomatis kehilangan ikatan perjanjiannya dengan Tuhan. Teologi Sinai yang dianut Mikha juga mewajibkan Israel mengolah tanah dengan baik; harus menjauhkan segala berhala dari tanah yang Tuhan berikan. Pelanggaran perjanjian ini berakibat buruk bagi Israel - yang dibuktikan dengan hancurnya Samaria yang kemudian diikuti Yehuda. ${ }^{127}$

\subsubsection{El Di Yehuda}

Pemilihan Yerusalem sebagai kota Yahweh yang sebelumnya merupakan kota orang Yebus dengan kultus Salem dan 'Ēlyōn yang sudah hadir sebelum Daud mengusai kota ini. Kultus

${ }^{127}$ Ibid., Cook, The Social Roots of Biblical Yahwism, 73-85 
yang hadir di Yebus ini kemungkinan besar memiliki ilah Sedek yang disembah oleh Melkisedek dalam Kejadian 14:18, yang dapat disejajarkan dengan dewa Salem yang merupakan ilah tertinggi Yebus dalam rekaman Mazmur 85. Selain itu, kultus El-'Ēlyōn juga identik dengan kota Yebus (penulis sudah membahas kultus El-'Ēlyōn dalam Bab II poin 2.2.14), merupakan kultus yang sudah pasti asing bagi umat Keluaran Mesir. Siknifikansi El- Ēlyōn terlihat Dalam Kejadian 14, yaitu ketika Yahweh diidentikkan dengan El-Elyon dalam kalimat

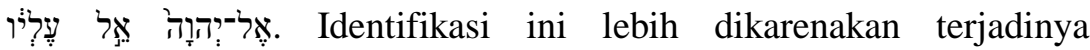
penggabungan kedua kultus tersebut di Yerusalem. Kemungkinan alasan penggabungan mereka, pertama: karena El dan Yahweh disetarakan dalam Ulangan 32 dan 14 - seperti yang telah dibahas penulis dalam Bab II dan IV. Kedua, tidak mungkin Allah Salem identik dengan Yahweh; mengingat Salem dipandang sebagai bagian dari Panteon El-'Ēlyōn. Dalam Mazmur 87:5-6, 91:1 dan pasal 47:3, Yahweh digambarkan identik atau berpasangan dengan 'Ēl -Elyon. 'Ēlyōn yang merupakan Allah kuno Yebus, muncul dalam inskripsi stela Sfire 1A (750 SM) yang berisi perjanjian antara raja Bargaya dan Attarsamek. Nama Ēlyōn hadir dalam inskripsi ini bersama-sama dengan nama-nama ilah lainnya seperti Marduk dan Shamash untuk menjadi saksi atas ikatan perjanjian tersebut. ${ }^{128}$ Dari Informasi Inskripsi Stela, 'Ēlyōn terlihat berbeda dengan 'Ēl - yang pada akhirnya berbeda juga dengan Yahweh. Untuk itu, teks tersebut sepertinya memberikan petunjuk bahwa Yahweh dan Ēlyōn mengalami kesejajaran hanya dalam berita Abraham yang dibangun oleh para penulis pasca Pembuangan. Konfirmasi kedua ilah ini sebagai figur yang berbeda dapat ditemukan dalam Ulangan 32:8-9 yang telah dibahas penulis dalam Bab IV. Dalam teks ini, 'Ēlyōn berperan sebagai kepala Panteon dan Yahweh sebagai bene ilm yang menerima instruksi.

${ }^{128}$ Ibid., Pritchard, ANET: SFIRE 1 A, Political Document, 659. 
Akan tetapi, dalam Dalam Mazmur 91: 1 istilah 'Ēlyōn terlihat dipergunakan sinonim dengan (Shadday) istilah kuno lainnya yang ditujukan kepada 'Ēl. Sedangkan dalam Mazmur 83, kita mendapati pemazmur berdoa agar bangsa-bangsa sekelilingnya dihukum dan dihancurkan. Tujuan dari penghancuran bangsa-bangsa sekeliling Israel ini untuk menunjukkan posisi Yahweh sebagai 'Ēlyōn atas seluruh dunia. Dari kedua Mazmur ini, kita menemukan istilah 'Ēlyōn yang dipergunakan atau sinonim dengan istilah Shadday dan Yahweh. Dari perbedaan antara kedua ilah tersebut - seperti yang terekam dalam inskripsi Sfire dan teks Ulangan 32:8-9, penulis melihat gambaran identik mereka dalam Mazmur 91, 87, 43 dan 83, menandakan tidak pernah ada konflik antara 'Ēlyōn dan Yahweh di Yehuda; atau sinkretisme antara kedua ilah tersebut di era Daud. Pertanyaan yang muncul adalah: apakah gambaran ideal Yahweh dan 'Ēlyōn dalam teks-teks Mazmur tersebut realitas Israel saat itu?

Dalam catatan 2 Raja-Raja 18:4, ada istilah massebah (tugu-tugu berhala dalam LAI) yang diperintahkan untuk dihancurkan dan dibakar. Terminology massebah yang muncul di sini umumnya berpasangan dengan Asherah. Dikarenakan massebah cenderung berpasangan dengan Asherah, dan pasangan Asherah hanya El atau Yahweh, maka masebah yang dimaksud dalam teks ini kemungkinan adalah Yahweh atau El. Namun dalam Hakim-Hakim 6:25, Gideon diperintahkan untuk menghancurkan altar $\mathrm{Ba}$ 'al bersama dengan tugu Asherah; dewi yang memainkan peran penting dalam tatanan agama Israel pra-Monarki dan Monarki. Dalam hal ini, tidak ada informasi munculnya massebah yang dihancurkan. Kemungkinan karena massebah dalam teks tersebut identik dengan kultus Yahweh. Jika menggunakan informasi dari inskripsi Kuntillet Ajrud dan Khirbet el Qom, maka, massebah yang menjadi pasangan Asherah adalah Yahweh. Akan tetapi, dalam kaitan dengan analisis penulis pada bagian ini, massebah yang muncul dan ditentang di sini bukanlah Yahweh, kemungkinannya adalah 'Ēlyōn atau El. Dalam perjalanan 
waktu di Yehuda, kita tahu peranan El semakin berkurang dari sistem agama Israel, yang mana di kemudian hari Asherah justru lebih sering digambarkan berpasangan dengan Yahweh di Israel dan Yehuda gambaran ini dapat ditemukan selain dalam catatan Kuntillet Ajrud, ditemukan juga dalam teks Perjanjian Lama saat Yosia melakukan reformasi di Bait Allah. Dalam Bait Allah tersebut, ditemukan dewa Molok, Dewa Matahari atau Milkom. Selain itu ditemukan juga Asherah dan Yahweh dalam bait Allah yang sama, beroperasi selama kurang lebih 300 tahun di Yerusalem.

Kesulitan menempatkan pasangan Asherah dalam analisis ini adalah: dengan siapa sesungguhnya Asherah berpasangan? Apakah ia berpasangan dengan El yang dikenal dengan 'Ēlyōn, atau dengan Yahweh? Jika berpasangan dengan Yahweh, mengapa dikecam dalam 2 Raja-Raja 14? Atau teks lainnya dalam Perjanjian Lama? Menurut penulis, 'Ēlyōn yang merupakan Allah utama Yebus sebelum Yahweh diperkenalkan memiliki pasangan yang disebut Asherah. 'Ēlyōn adalah massebah yang ingin dihancurkan para pengikut Yahweh. Akan tetapi, ketika melihat Asherah muncul berpasangan dengan Yahweh dalam inskripsi Kuntillet Ajrud, maka kita otomatis mendapat kesulitan dalam menentukan "siapa menghakimi siapa?" Jawaban yang dapat diterima dari kesulitan di atas adalah menjelaskan bahwa 'Ēlyōn dengan Asherah pernah bersanding menjadi ilah utama, mereka menjadi pasangan ilah yang disembah sebelum agama Yahweh muncul, atau sebelum Daud menaklukkan Yerusalem dan memperkenalkan Yahweh, atau sebelum ide sentralisasi Yahweh dijalankan di Yerusalem. Ketika Yahweh diperkenalkan di Yerusalem, 'Ēlyōn otomatis memiliki rival sekaligus sahabat. Itulah seBabnya 'Ēlyōn dalam teks Sfire digambarkan sendiri, namun dalam teks Mazmur, ia identik dengan Yahweh. Hal ini dapat terjadi karena pada waktu terkemudian, 'Ēlyōn yang mulai kehilangan peran dan pengikutnya, berbanding terbalik dengan Yahweh yang mulai menanjak, kemudian naik tahta menjadi satu-satunya Allah bergender 
maskulin, memerintah Yehuda dengan Asherah berada disampingnya. Naiknya Yahweh menjadi ilah utama persis seperti yang Mark S. Smith argumentasikan: Allah level dua (Yahweh), naik menjadi Allah level 1 menggantikan El - sekaligus membawa epitet yang sebelumnya menempel pada El atau 'Ēlyōn. Identifikasi inilah yang dipergunakan teks-teks Perjanjian Lama; seperti Mazmur untuk menyatakan Yahweh dan 'Ēlyōn setara. Ini adalah gambaran rill bentuk keagamaan Yehuda sebelum reformasi; yang bisa dideskripsikan sebagai politeistik atau monolatri.

Akan tetapi, Argumentasi di atas menurut penulis akan menemukan kesulitan apabila menempatkan teks seperti 2 Raja-Raja 18:4: perihal penghancuran massebah dan Asherah dalam konteks di atas. Menurut penulis tulisan seperti ini muncul dalam konteks kepenulisan $\mathbf{J}$ (yang notabene berpihak pada Yehuda).Teks ini akan dimengerti sebagai teks Pembuangan, walaupun hadir tradisi Patriak dalam narasinya. Ide monoteisme dan universalisme Yahweh hanya hadir pada era pembuangan. Oleh karena itu, semua teks yang tercipta pada era ini - walaupun berisi narasi Patriakal, telah mengalami perubahan dan editing supaya mampu beradaptasi dengan situasi Pembuangan yang Israel alami. Jika sumber kepenulisan ini yang dipergunakan untuk membaca hubungan antara 'Ēlyōn dan Yahweh di Yehuda, maka kita menemukan hadirnya hubungan tidak harmonis antara keduanya. Menempatkan 'Ēlyōn dengan Yahweh dalam konteks Pembuangan pada akhirnya meletakkan pengikut Yahweh melakukan sinkretisme dengan massebah yang identik dengan 'Ēlyōn; yang merupakan model penyembahan Kanaan; dalam hal ini penyembahan orang Yebus sebelum Daud menguasai kota ini. 


\section{Bab IV}

\section{Modifikasi Dan Perkembangan Yahweh Di Era Monarki}

Yahweh yang diperkenalkan oleh Musa merupakan Allah yang memimpin dan menuntun Israel keluar dari pembuangan. Yahweh dianggap sebagai Allah pembebas, pemberi kemenangan dan pemberi hukum kepada Israel. Yahweh juga dipandang sebagai Allah yang berbeda dengan El yang disembah oleh para Patriak, walaupun dari aspek psikologi dapat dikatakan Yahweh merupakan muara dari sederet janji-janji yang diberikan Allah Patriak. Dalam diri Yahweh semua janji digenapi dan Israel merupakan penerima semua janji tersebut.

Konsep Yahweh di atas masih dipergunakan pada era Monarki di mana Saul menjadi raja. Yahweh masih dipandang sebagai Allah yang memberikan kemenangan kepada setiap tindakan Israel; khususnya dalam hubungan mempertahankan wilayah Kanaan dari bangsa-bangsa sekitar Israel. Namun demikian, Saul yang identik dengan raja perang, berkontribusi besar atas inovasi (evolusi) Yahweh dari Allah padang gurun pembebas dan pemberi ikatan perjanjian, menjadi Yahweh Allah kerajaan yang militeristik dan peperangan. Yahweh menjadi Allah perang bagi Israel dalam upaya mempertahankan sekaligus meluaskan wilayah yang diklaim sebagai bagian dari ikatan perjanjian Yahweh dengan Israel yang belum diperoleh saat itu.

Allah lain seperti El, Asherah dan Ba'al menjadi AllahAllah sesembahan Israel era Monarki Saul; terutama El dan Yahweh yang memainkan peran utama di Utara Israel tersebut seperti yang terekam dalam narasi raja Saul dan Hosea sang nabi. Hal ini hanya mungkin terjadi karena Saul yang berasal dari wilayah Benyamin; lebih tepatnya Gibeah merupakan klan penyembah Yahweh sejak 
mulanya. Yahweh merupakan Allah keluarga Saul sebelum ia menjadi raja. Ketika ia menjadi raja atas Israel, Yahweh otomatis dijadikan sebagai Allah nasional saat itu. Bahkan jauh setelah Saul tiada, Yerobeam tetap mempertahankan ide penyembahan kepada Yahweh dengan mendirikan kultus Yahweh di Betel dan Dan berupa patung lembu jantan yang digadang-gadang sebagai model penyembahan yang mengekor dari kultus Yakub dan Harun sebelumnya.

Demikian pula penyembahan terhadap El di Israel yang tak terbilang banyaknya terus bertahan sampai kemudian mendapat sentiment negatif dari Hosea. Namun sentiment negatif yang keluar dari mulut Hoses tersebut disinyalir merupakan suara pasca Pembuangan yang berupaya menempatkan Yahweh sebagai satusatunya Allah nasional Israel dengan menyingkirkan $\mathrm{El}$ yang sebelumnya menjadi Allah nasional Israel.

Sedangkan Yahweh yang beroperasi di Yerusalem dan Sion dapat dikatakan sebagai kelanjutan dari Yahweh Sinai dengan sedikit inovasi dan modifikasi sana-sini yang dilakukan oleh beberapa individual yang dikenal sebagai nabi, diantaranya: Yesaya, Hosea dan Mikha, di mana ketiganya terkenal dengan ideologi Sinaitik yang berhubungan dengan Yahweh yang berasal dari Sinai. Bagi ketiga nabi tersebut, Yahweh yang berada di Sion dan Yerusalem tidak saja sebagai Allah pembebas dan pemberi hukum, namun Ia menjadi Allah yang terkenal dengan ikatan perjanjiannya; terutama pembaharuan ikatan perjanjian. Ikatan perjanjian yang pernah diberikan kepada para leluhur, diterima Israel dan telah dilanggar Israel saat itu. Teologi Sinai yang hadir dalam diri Yahweh Di Yerusalem dan Sion memberikan penekanan pada keharusan melakukan "pembaruan perjanjian" yang telah dilanggar Israel saat itu. Gambaran Allah perjanjian ini merupakan echo dari Yahweh yang memberikan atau membangun ikatan perjanjian dengan Israel saat mereka di padang gurun. Namun yang membedakan dalam konteks Yerusalem ini 
adalah, Israel didapati telah melanggar ikatan perjanjian, oleh karena itu wajib melakukan pembaruan pada ikatan perjanjian itu. Jika mereka menolak, maka Israel akan dimuntahkan dari Kanaan mengingat ikatan perjanjian ini memiliki poin penting yang berhubungan dengan tanah.

Selain Yahweh yang dikenal sebagai Allah yang melakukan pembaruan ikatan perjanjian, penulis melihat Yahweh yang digambarkan bertahta atau berdiam di Yerusalem dan Sion, telah memiliki tempat permanen untuk berdiam. Tentunya konsep ini berbeda dengan Yahweh era padang gurun yang berpindah-pindah tempat kediamannya. Penulis juga melihat hadirnya pengaruh El dan Ba'al dalam konsep Yahweh yang berdiam di Yerusalem dan Sion ini. El dikenal memiliki tempat kediamannya di gunung kudus yang disebut gunung Li dan Ba'al memiliki gunung kudusnya sendiri yang disebut gunung Sapan. Penggunaan Yerusalem dan Sion sebagai gunung Tuhan nampaknya berakar pada ideology El dan Ba'al di atas.

Yahweh yang berdiam dalam gunung kudusnya di Yerusalem dan Sion menjadi cikal bakal dari sentralisasi Yahweh dikemudian hari yang berujung pada monoteisme Israel. Selain itu, sentralisasi Yahweh secara otomatis menciptakan kesatuan politik dan keagamaan Israel dalam skala nasional di Yehuda, sekaligus menjadi jaring penguat bagi perkembangan Monarki itu sendiri. Sentralisasi ibadah memberikan keuntungan bagi kekuatan politik dan ekonomi. Pemisahan diri Yerobeam atas Yehuda merupakan ancaman nyata atas kesatuan politik, ekonomi dan keagamaan Yehuda, oleh karena itu harus ditentang.

Di Sion Yahweh diketahui mendapat sebutan elohei samayim atau Yahweh Sevaot "Pahlawan Balatentara Tuhan." Julukan ini sebelumnya lekat kepada El yang juga disebut sebagai Pahlawan Balatentara Tuhan dalam naskah Ugarit (du Yahwi saba'ot), yang juga dapat berarti "dia yang menciptakan Bala tentara Tuhan." Gambaran Yahweh sebagai pahlawan gagah perkasa dalam teologi 
Sion yang merupakan echo dari gambaran El di Kanaan, menurut penulis merupakan warisan yang diturunkan oleh Saul dengan konsep Yahweh yang militeristik, di mana Yahweh sedang memanggil seluruh ciptaannya; dalam hal ini Israel untuk maju berperang; sekaligus masih dipengaruhi oleh sistem agama El; paling tidak epitet El yang melekat pada Yahweh.

Yahweh Sinai dalam gambaran ini telah mendapat modifikasi atau dapat dikatakan berkembang dalam konteks sebagai Allah perang; sekaligus menjadi Allah pembaharu ikatan perjanjian dan simbol sentralisasi politik dan agama ketika berada di Yerusalem dan Sinai selepas Israel masuk Kanaan. Inovasi dan perkembangan penting terjadi melalui individu-individu tertentu yang memainkan peran utama di Israel seperti Saul, Yesaya atau Mikha dan Hosea. Dalam konteks ilah Yahweh yang telah dibahas, perubahan dan perkembangan tidak meninggalkan warna asli dari Yahweh yang mula-mula dikenal oleh Musa. Akan tetapi dalam konteks dan perkembangan selanjutnya yang lebih luas, kultus Yahweh dapat juga digambarkan sebagai kultus monoteistik sekaligus politeistik atau monolatri. Gambaran terakhir ini menurut penulis dapat terlihat dari bervariasinya nama, tempat dan pola penyembahan Yahweh dan El di seluruh Israel; belum lagi penyembahan terhadap $\mathrm{Ba}$ 'al, Asherah, Anat dan dewa lainnya di Israel saat itu. Ide sinkretisme tidak mungkin diaplikasikan dalam dunia kuno Israel yang melihat penyembahan terhadap ilah berbeda merupakan bentuk monoteisme.

Kembali kepada Yahweh sebagai simbol sentralisasi politik dan agama di Yehuda, ide sentralisasi Yahweh yang dimulai di Yerusalem ini - yang kemudian terkenal dengan 'pergerakan Yahweh semata' (Yahweh only) pada akhirnya bermuara pada konflik global. Elia dan Elisha yang dipengaruhi oleh pergerakan sentralisasi Yahweh yang berlangsung di Israel dan Yehuda harus berbenturan dengan ilahilah lain yang sebelumnya legal beroperasi di Israel' seperti El, Asherah dan Ba'al. Bahkan perubahan atau perseteruan ini beroperasi 
jauh di luar teritorial Israel yang dapat terlihat dalam narasi Naaman (2 Raja-Raja 5) di mana karya Yahweh terdengar dan berlaku melampaui batas-batas Israel itu sendiri yang keluar dari mulut Naaman mengenai tidak ada Allah yang luar biasa hebat selain Allah Israel.

Sentralisasi Yahweh di Israel dan Yehuda menempatkan Yahweh yang semula merupakan ilah level dua dalam hipotesa Mark S. Smith dan Lowel K. Handy, bergeser menjadi Allah level satu. Peran ilah level satu yang selama ini dipegang oleh El perlahan-lahan menghilang digantikan oleh Yahweh. Penggunaan figur El sebagai Allah sesembahan Israel yang sebelumnya massif digunakan, perlahan-lahan mulai luntur di Israel yang diseBabkan oleh beberapa hal. Pertama, sentralisasi Yahweh yang berujung kepada monoteisme telah memainkan peran besar di Israel; terutama melalui kaum Deuteronomis dan nabi-nabi pengusung ide "Yahweh semata." Kedua, penurunan penggunaan nama El sebagai sesembahan Israel disebabkan sulitnya membedakan El sesembahan Israel dengan El sesembahan Kanaan. Artinya, Israel yang berusaha melakukan sentralisasi politik dan agama atas nama Yahweh yang kemudian akan bermuara kepada monoteisme, harus menghilangkan semua unsur politeisme yang melekat dalam sistem agama mereka sebelumnya; terutama sistem Panteon yang mereka miliki yang identik dengan Panteon Kanaan. Padahal telah diketahui sebelumnya bahwa Yahweh selama ini disejajarkan dengan $\mathrm{El}$, bahkan mengambil dan mengadopsi banyak epitet yang biasa dikenakan kepada El. Selain El yang mengalami tekanan dari meluasnya kekuasaan Yahweh, para ilah level dua lainnya seperti Ba'al dan Anat mendapatkan tekanan secara politik dan religious yang lebih kuat lagi. Ba'al yang diketahui mendapat cercaan dan dipandang sebagai kejijikan bagi Israel terusmenerus mendapat label allah palsu; walaupun ada fakta di mana Daud pernah memuji Ba'al dengan sebutan Ba'al Perasim: "Allah yang memberikan terobosan" saat ia berhadapan dengan orang 
Filistin. Daud yang menggunakan nama Ba'al yang ditujukan kepada Yahweh saat itu tidak menggentarkan Elia untuk mengutuk para nabi Ba'al di gunung Karmel.

Monarki dipastikan memainkan peran penting memberikan label 'ilah lain' kepada El, Asherah, Ba'al, Anat dan Allah lainnya yang disembah di bamot, yang dilawankan dengan Yahweh - sekaligus Monarki memberi andil tetap bertahannya para ilah di atas dalam konstelasi ilah yang disembah di Israel dan Yehuda. Pernyataan penulis; khususnya Monarki masih memberi andil bagi bertahannya ilah-ilah non Yahweh di Israel ini dapat dibuktikan ketika Yosia melakukan reformasi di Bait Allah Yerusalem. Dalam bagian ini dikatakan Yosia membakar patung Asherah, dewa Molok dan dewa-dewi lainnya yang selama kurang-lebih 300 atau 350 tahun berada dalam bait Allah Yerusalem; disembah dan dihormati oleh orang Israel. Hal ini memperlihatkan orang Israel menetapkan Yahweh sebagai Allah nasional; baik di utara maupun Yehuda sekaligus tidak mampu meninggalkan penyembahan terhadap ilah lain; utamanya El, Ba'al dan Asherah yang sebelumnya merupakan Allah suku yang disembah oleh Israel dalam bamot-bamot yang dikenal dengan Shiloh, Betel, Bersheba atau Mamre - fakta bahwa Elia tidak membunuh para nabi Asherah di gunung Karmel, membuktikan argumen ini.

Namun demikian, penulis melihat spirit Elia dan Elisha yang mengusung konsep Yahweh versus ilah-ilah lain dalam konteks Kanaan mendapat tempat sangat luas dalam catatan Perjanjian Lama: dalam teks-teks hukum; profetik; Mazmur dan dalam narasi sejarah. Catatan ini mengindikasikan peran Yahweh yang besar untuk menjadi satu-satunya Allah di Israel walaupun pada saat bersamaan penyembahan terhadap terhadap Ba'al pada sekitar abad 9 SM sangat kuat. Menurut Cross, persoalan perseteruan ini bukanlah mengenai Yahweh akan kehilangan pemilih dan pengikutnya, melainkan posisinya yang disejajarkan atau akan disejajarkan dengan allah-allah 
Kanaan lainnya. ${ }^{129} \mathrm{Hal}$ ini tentu saja mengherankan sebab Yahweh sebelumnya banyak menggunakan epitet Ba'al untuk menunjukkan jati dirinya yang tergambar dalam catatan Perjanjian Lama.

Jejak-jejak Ba'alisme dalam Yahwistik pada masa Monarki dapat terlihat dalam beberapa bagian Perjanjian Lama yang beberapa diantaranya adalah pertama, terlihat dari banyaknya namanama orang Israel pre-Monarki yang menggunakan nama Ba'al untuk menunjukkan dirinya teridentifikasi dengan objek dan subjek sesembahannya (Ba'al), seperti Meribaal, Yerubaal, dan Ba'al Perazim yang dikumandangkan Daud ketika ia memuji Allah karena kemenangan yang diberikan dalam pertempuran. Kedua, tidak dapat dipungkiri bahwa umat Israel pernah menyembah $\mathrm{Ba}$ 'al dengan esensi Yahweh. Contohnya Daud yang menyebut Yahweh dengan sebutan Ba'al Perazim karena telah memberikan terobosan (1 Taw. 14:11) dan Abimelek anak Gideon dari istri orang Sikem yang menyembah Baal Berit (Hak. 9).

Julukan "yang maha tinggi" milik Baal yang terdapat dalam teks Ugarit (CAT 1.16 III 6, 8), muncul sebagai julukan terhadap Yahweh dalam 1 Samuel 2:10, 23:1, Maz. 18, 68, dan lainlain, dalam format $y h w ' l y$ "Yahu sang maha tinggi", lyhw, "maha tinggi Yahu" dan lyw "tinggilah Yahu." ${ }^{130}$ Seperti Ba'al yang digambarkan berperang dengan Yamn dan Mot-dewa kematian dalam mitologi Kanaan, ${ }^{131}$ demikian pula Musa, ia menggambarkan bagaimana Yahweh mengalahkan pasukan Mesir yang terekam dalam nyanyian musa di Keluaran 15:1-18. Nyanyian ini memuji Yahweh yang menggunakan laut sebagai instrumen untuk menenggelamkan pasukan Mesir dan memberi kemenangan bagi Israel. Serupa dengan cerita Ba'al yang berdiam di gunung Zaphon sebagai gunung

${ }^{129}$ Ibid., Cross, Canaanite Myth and Hebrew Epic, 213.

${ }^{130}$ Ibid., 45, 93-94.

${ }^{131}$ E. Theodore, Mullen, The Divine Council in Canaanite and Early Hebrew Literature, (Massachusets: Scholars Press, 1978), 144-145. 
kudusnya, Yahweh juga diberitakan mendirikan kediamannya di atas gunung sebagai tempat kudusnya (ay.17); dalam hal ini gunung Sion. Dari kesamaan yang muncul di atas, maka terlihat tulisan Musa memiliki struktur mitologi Ba'al dalam nyanyiannya. Dengan kata lain, Musa jauh sebelum era Kerajaan hadir telah memahami mitologi Ba'al dan mempergunakan banyak hal yang berkenaan dengan Ba'al yang diasosiasikan kepada Yahweh.

Bahkan penulis melihat tradisi dewa badai di atas tetap terpelihara dalam beberapa Mazmur; seperti Mazmur 46:7: 93:3-4: 97: 1-6 dan Mazmur 144. ${ }^{132}$ Dalam Mazmur di atas, "Yahweh dikatakan mengaum dari Zion, dari Yerusalem ia memperdengarkan suaranya, keringlah padang-padang penggembalaan, dan layulah puncak gunung Karmel (Amos 1:2).” Juga sosok Lewiatan (Yam) yang merupakan musuh Baal dalam naskah Ugarit (CAT. 5.1), muncul sebagai lawan Yahweh dalam Yes. 27:1, Maz. 104 dan Maz. 74. Sehingga tepatlah jika terlihat dalam teologi kerajaan Israel dan Yehuda, pola-pola mite Ba'al sering diasosiasikan dengan Yahweh. Mazmur 89 yang merupakan Mazmur kerajaan menggambarkan kemenangan Yahweh atas samudra dan semua musuh kosmis. Demikian juga Mazmur 72:8 yang menempatkan Yahweh mendominasi atas samudra dan seluruh sungai bahkan seluruh dunia. Mazmur-Mazmur ini nampaknya memiliki echo dari kemenangan Ba'al atas samudra (Yam), dan tetap mempertahankan dirinya sebagai Raja. Selain itu, Ba'al yang juga dikenal sebagai "pahlawan gagah perkasa," motif " pahlawan gagah perkasa ini" kemudian diambil dan dilekatkan kepada Yahweh sebagai pahlawan perkasa yang berperang di depan umatnya Israel.

Semua gambaran di atas punah dalam pemandangan Elia dan Elisha. Yahweh meninggalkan semua kenangan bersama Ba'al. Yahweh tidak lagi datang dalam angin, badai, api, petir dan Guntur,

${ }^{132}$ G.S. Kirk, Myth: Meaning and Functions in Ancient and Other Culture, (Cambridge: University Press, 1970), 213 
melainkan ia datang berbisik ke dalam hati setiap umatnya. Gambaran ini tentu saja menimbulkan pertanyaan dan polemik: bagaimana mungkin gambaran yang sudah ratusan tahun menempel dan dipergunakan dalam diri Yahweh, ditolak sedemikian rupa pada akhirnya? Apakah ini realitas yang terjadi dalam praktek ataukah realitas yang terjadi dalam tataran ideologi? Menurut penulis hal tersebut di atas terjadi dalam alam realitas Israel sekaligus terjadi dalam tataran ideologi.

\subsection{Yahweh Ehad Monarki}

Ide sentralisasi Yahweh yang tergambar pada era Monarki pada akhirnya akan berujung pada monoteisme Israel. Namun sebelum era monoteisme tersebut menjadi kenyataan, Israel masih tetap dalam pola Monolatri, Henoteisme atau Politeisme yang tidak menjadi masalah bagi mereka saat itu. Yahweh menjadi sesembahan tanpa meninggalkan penyembahan pada El, Asherah atau Ba'al sebagai Allah Israel. Semua ini akan berubah ketika mereka masuk dalam pembuangan; terutama dalam kacamata para reformator Israel yang berupaya menempatkan Yahweh menjadi satu-satunya Allah Israel yang diproklamasikan dalam Ulangan 6:4: Dengarlah, hai orang Israel: TUHAN itu Allah kita, TUHAN itu esa! Padanan ayat di atas dapat dilihat dalam: Ul.4:35, Ul. 4:39, Ul.5:7, Ul. 7:9, Ul.10:17, Ul. 32:29, Ul. 33:26.

Seluruh teks di atas menurut Mac Donald, ${ }^{133}$ merupakan pengakuan Deuteronomi terhadap Yahweh yang beroperasi dalam masing-masing konteksnya. Dari semua teks di atas, Mac Donald melihat Ulangan 6:4-9 yang memiliki istilah shema menunjukkan pernyataan mengenai kesatuan Yahweh (Yahweh oneness). Shema menurut Mac Donald memainkan peran penting dan utama dalam

133 Natan Mac Donald, Dissertation: One God or one Lord?: Deuteronomy and the Meaning of Monotheism, Mohr Siebech, (Tubingen: Germany, 2012), 97-104 
tradisi Yahudi dan Kristen. Yahudi menggunakan shema sebagai bagian pembuka dan pembukaan doa setiap hari. Bagi kekristenan, shema, diterima sebagai perintah terbesar. Dalam Sejarah Perjanjian Lama, shema dipahami sebagai slogan reformasi Yosia. Shema selalu berada di bagian depan kehidupan Israel yang tidak memiliki paralelnya di bagian manapun teks Ibrani. Namun demikian, para ahli nampaknya mengalami kesulitan menterjemahkan istilah Yahweh Elohim Yahweh ehad. Menurut Mac Donald, persoalan terletak pada titik mengkombinasikan setiap kata-kata tersebut di atas. Empat pertanyaan sulit yang muncul adalah: pertama: dalam konteks apa seharusnya teks ini dibaca? Kedua, apakah kata kerjanya dalam bentuk tersamar, dan jika tidak, bagaimana kata kerja ini seharusnya dipahami? Ketiga? Manakah yang menjadi predikat dan mana yang menjadi subjek? Keempat, apakah arti melampirkan 4 tafsiran/terjemahan dari teks Ul. 6:4-9; khususnya mengenai אחד
1. YAHWEH is our God; YAHWEH is one;
2. YAHWEH, our God, YAHWEH is one;
3. YAHWEH, our God, is one YAHWEH;
4. YAHWEH is our God, YAHWEH alone.

Veijola dan Loretz menterjemahkan poin 1 sebagai 'you are my God' and 'I am your God.' yang pertama mengidentikkan Yahweh sebagai Allah Israel. Kalimat kedua menyatakan bahwa hanya Yahweh satu-satunya yang menjadi Allah Israel. Terjemahan poin 2 memahami kata kerja sebagai predikat bersama dengan yang juga sebagai predikat. Translasi ini didukung oleh beberapa varian teks awal (Septuaginta, Vorlage dan Papirus Nash). Mac Donald mencatat ada 2 kelemahan dalam terjemahan ini: pertama, Yahweh kedua menjadi tidak efektif (baca: tidak berguna), kedua, hubungan subjek - predikat menjadi problematik dalam 
mengklasifikasi kalimat ini. Poin ketiga, Yahweh, our God, is one Yahweh, menurut Mac Donald menyelesaikan masalah Yahweh yang diulang haruslah dengan memahaminya sebagai kata predikat tunggal. Dengan "Yahweh Allah kita" sebagai subjek dan "Yahweh satu" sebagai predikat." ${ }^{34}$ Bagi Mac Donald, kalimat ini menjadi slogan mono-Yahwism yang berfungsi sebagai pembeda dengan banyaknya tempat kudus yang menjadi lokasi penyembahan Yahweh dengan bentuk dan tradisi berbeda; yang mana dalam pergerakan Deuternomis dinyatakan sebagai hanya satu Yahweh yang harus disembah dalam satu sanctuary. Sedangkan poin ke 4, Yahweh is our God, Yahweh alone, yang diterjemahkan sebagai "Allah kita adalah Yahweh, Yahweh saja", dipandang Mac Donald bermasalah dengan tiga alasan: Pertama, tidak konsisten dengan penggunaan Yahweh dan Eloheinu dalam Deuteronomi. Kedua, istilah אחד אang berdiri dengan kalimat ini tidak dipahami berfungsi sebagai kata sifat. Ketiga, harus ditetapkan apakah אח אד bisa berfungsi sebagai kata sifat jika dipasangkan dengan kata "alone." Bagi Mac Donald, Ulangan 6:4b harus dibaca dalam konteks Deuteronomi dan dipahami sebagai " $a$ single predication, with אחד as the predicate", sehingga menjadi 'Yahweh, our God, is one Yahweh', yang pada akhirnya menjadikan Ulangan 6:4 sebagai pernyataan mono-Yahwisme yang tentu saja berlawanan dengan keberadaan poli-Yahwisme di Israel sebagai respon Deuteronomi terhadap apa yang dinamakan inskripsi Kutillet 'Ajrud yang memiliki referensi 'Yahweh dari Teman' dan 'Yahweh dari Samaria'. Mono-Yahwisme yang tetap menyediakan ruang bagi keberadaan Allah lain di Israel (in se memberikan fakta kehadiran Allah lain tidak mungkin dihilangkan dalam catatan Ibrani) dimaksudkan oleh Deuteronomi sebagai upaya untuk memanggil kembali Israel kepada pengakuan bahwa Yahweh adalah unik di Israel, dan mereka harus menerima serta menyembahNya dengan

${ }^{134}$ Ibid., Mac Donald, One God or one Lord? 101-107. 
sepenuh hati. Hal ini pada akhirnya berhubungan dengan perintah pertama Dekalog; di mana kalimat 'al panay' yang dalam terjemahan mayoritas teks Jerman menjadi "di sebelah aku"; parallel dengan U1. 32:39 'tidak ada Allah lain dengan ku.' Pengertian kedua atas teks yang berbunyi 'diseberang aku, didepan wajahku' - adalah perintah yang melarang meletakkan berhala apapun di hadapan Yahweh. Namun bagi Mac Donal, terjemahan di atas bermasalah mengingat istilah 'al panay' lebih mendekati pada 'on the surface of' (Kej. 1:2) yang sering muncul dalam ekspresi "bersujud di depan seseorang." Untuk itu Mac Donald mengusulkan penggunaan 'al panay' di manapun dalam Perjanjian Lama Seharusnya berbunyi "You shall have no other gods over and against me." Allah lain adalah ancaman terhadap Yahweh dan mengikuti mereka merupakan tindakan pembangkangan. Shema dan Perintah Pertama mengklaim bahwa hanya Yahweh satu-satunya Allah Israel. Bangsa lain juga memiliki Allah, namun menyembah mereka dilarang. Dalam rancang pembicaraan para ahli modern, kepercayaan ini disebut monolatri. Namun dalam pembacaan awal Deuteronomi, dimana shema dan perintah pertama ditemukan, merupakan panggilan untuk menyembah Yahweh saja - teks ini dibaca dalam pemikiran monoteistik (UL.6:4) yang merupakan karya editorial - telah menjadikan 'kesatuan Yahweh' (Yahweh oneness) sebagai tema sentral Deuteronomi yang dimulai dari pembacaan Ulangan 4:35, 39 ketika Yahweh dinyatakan sebagai satu-satunya Allah. Kedua teks ini menurut para ahli modern merupakan ekspresi nyata ide 'monoteisme'. ${ }^{135}$

Ulangan 4:35, 39 merupakan pengakuan Yahweh sebagai Allah Israel, yang sekaligus unik dan terefleksi dalam kalimat $h a$ Elohim. Pernyataan dalam shema, perintah pertama dan Ulangan 4:35, 39 sama-sama memiliki klaim penolakan akan ilah lain dalam kehidupan Israel, seBab Yahweh adalah unik. Ulangan 4 merupakan kulminasi dari argumen pengalaman Israel di Mesir dan Sinai, di

${ }^{135}$ Dalam daftar BHS tidak terdapat variasi tekstual yang siknifikan 
mana Israel dipanggil untuk mengenal dan mengakui keunikan Yahweh, yang menjadi Allah mereka satu-satunya dengan konsekuensi menolak ilah lain. Sedangkan perintah pertama terekspresi dengan munculnya 'larangan keras'. Pada akhirnya dalam shema, Yahweh adalah unik bagi Israel sebagai dasar penyembahan sepenuh hati kepada Yahweh (Ul. 6:5); sekaligus menjadi tema Ulangan 6-11. Siknifikansi shema (U1. 6:4-9) secara nyata diindikasikan oleh banyak faktor; termasuk di dalamnya ditempatkannya frasa ini dalam struktur Deuteronomi dan panggilan empatik bagi devosi sepenuh hati Israel. Yahweh adalah satu, Yahweh satu-satunya Allah Israel, tidak ada lainnya - korelasinya terdapat dalam perintah pertama. ${ }^{136}$

\subsection{Yahwisme Era Pasca-Pembuangan}

El dan seluruh sidang ilahinya berakhir pada era gerakan Yahwistik muncul dalam kelompok Deuteronomis - yang menempatkan Yahweh menjadi Allah tunggal yang diakui. Pada era Pembuangan dan pasca Pembuangan, Yahweh seolah-olah kehilangan kekuatannya karena membiarkan umatnya dibuang. Akan tetapi kita melihat bahwa kehancuran Bait Allah dan hilangnya negara, tidak menjadikan Yahweh hilang atau kalah. Mungkin Deutero Yesaya secara umum menggambarkan bagaimana Yahweh tetap berkuasa dalam kehancuran Israel; ia membiarkan Israel hancur sebagai bagian dari rangkaian penghukuman terhadap mereka. Para pengikut setia Yahweh tetap mengupayakan hadirnya Yahweh dalam situasi sulit Israel saat itu. Mereka mengembangkan kredo atau tradisi-tradisi Yahweh yang berhubugan dengan kerajaan Daud untuk mengingatkan Israel bahwa Yahweh tetap setia pada ikatan perjanjian yang pernah ia buat dengan mereka. Yahweh adalah Allah yang membuat ikatan perjanjian dengan Musa, dilanjutkan dengan Daud yang dimateraikan di Sion. Janji dan pembaharuan ikatan perjanjian ini akan kembali

${ }^{136}$ Ibid., Mac Donald, One God or one Lord? 108-123. 
diperbaharui dan diberikan kepada Israel dalam menghadapai situasi baru yang mereka alami, sekaligus untuk jadi pengingat mereka akan Yahweh. Dengan kata lain, tradisi Sinai dan Sion dikembangkan sedemikian rupa untuk menjadi bahan kajian dan ingatan bagaiman Yahweh tidak pernah melupakan umatnya.

Apabila memperhatikan kitab Hagai 2:20-23, maka kita akan menemukan nubuatan Mesianis yang ditempelkan dalam bingkai Yahweh yang memperbaharui ikatan perjanjiannya dengan Israel. Ayat 22 berbunyi: “...dan akan menunggangbalikkan takhta raja-raja; Aku akan memusnahkan kekuasaan kerajaan bangsa-bangsa dan akan menjungkirbalikkan kereta dan pengendaranya; kuda dan pengendaranya akan mati rebah, masing-masing oleh pedang temannya..." Ayat ini jelas memberikan jaminan pembaharuan dan jaminan keamanan bagi Israel yang dalam pembuangan. Zakaria pasal 4 memberikan gambaran yang seperti dimiliki Hagai pasal 2. Dalam teks nubuatan ini, Zakaria berbicara mengenai kekuasaan Tuhan yang memulihkan dan mendirikan Israel kembali.

Pada akhirnya kita melihat munculnya keberagaman agama - khususnya keberagaman Yahwistik dalam wacana Israel lebih khusus lagi pada era Persia. Keberagaman dalam penyembahan terhadap Yahweh dalam era akhir Persia dan awal Helenistik hadir sebagai akibat dari pemisahan geografis antara komunitas Yahudi di Samaria, Yehuda, Babilonia, Mesir (Elam, Alexandria), dan lain sebagainya. Yudaisme tidak memiliki titik pusat ibadah pada era ini. Sejarah mencatat hadirnya empat kuil Yahudi, dan mungkin ada lainnya dalam periode Persia dan Helenistik ini. ${ }^{137}$ Bait Allah ini termasuk: pertama, Bait Allah kepada Yahweh di Elam, Mesir - di mana orang Yahudi membangun bait Allah ini sebelum tahun 525

${ }^{137}$ Bezalel Porten, Archives from Elephantine: The Life of an Ancient Jewish Military Colony (Berkeley: University of California Press, 1968), 292. 
SM, dan dihancurkan tahun 410 SM. ${ }^{138}$ Kedua, Bait Allah di Gunung Gerizim - Bait Allah yang menurut para ahli - yang mengikuti tafsiran Yosefus - dibangun pada era Helenistik. Namun arkeologi mengasumsikan Bait Allah ini dibangun sekitar pertengahan abad 5 SM, dan bertahan sampai era Ptolomeus. ${ }^{139}$ Bait Allah ini banyak dipengaruhi kultur dan sistem agama Fenisia. Ketiga, ada Bait Allah Yerusalem, yang direnovasi pada abad 515 SM di bawah pemerintah ZeruBabel, yang juga dilanjutkan pada era Nehemia. Keempat, terdapat istilah $B Y T Y W H$ di Idumea. Dalam ostraca Idumea, ditemukan catatan mengenai hancurnya $B Y T Y W H$ di Idumea, lokasi tepatnya di sekitar Khirbet el Qom/ Makkada. Dilihat dari perbandingan Epigrafi, bait suci ini muncul pada era Babilonia atau periode Persia. Teks Idumea ini juga memberikan rujukan hadirnya bai Allah " $B Y T Z$ (bait Allah Uzza) dan BYT NBW (bait Allah Nabu) yang merujuk kepada penyembahan akan Yahweh. ${ }^{140}$

Dengan data dan fakta di atas, kita dapat simpulkan bahwa pada era Persia dan awal Helenistik, terdapat banyak Bait Suci Yahweh yang beroperasi di wilayah luar Yerusalem yang pernah menjadi daerah kerajaan Israel dan Yehuda. Kehadiran dan kompetisi Bait Suci Yahweh pada periode ini mungkin (atau pasti) menjadi ancaman terhadap identitas Bait Suci Yerusalem yang dikenal sebagai pusat sesungguhnya dari agama Yahwisme. Kehadiran dari beberapa Bait Suci Yahweh di luar Yerusalem tersebut mengindikasikan munculnya kembali (re-emergence) poly-Yahwisme - bervariasinya Yahwisme dari satu Bait Allah kepada Bait Allah lainnya. Kemunculan kembali poly-Yahwisme dalam era Persia dan

${ }^{138}$ Stephen G. Rosenberg, "The Jewish Temple at Elephantine," NEA 67:1 4-13, (2004), 9.

${ }^{139}$ Ephraim Stern and Yitzhak Magen, “Archaeological Evidence for the First Stage of the Samaritan Temple on Mount Gerizim," IEJ 52 (2002), 49-57

140 Andre Lemaire, "New Aramaic Ostraca from Idumea and Their Historical Interpretation," in Judah and Judeans, 416-417. 
Helenistik ini bagi penulis memiliki akar kuat di Israel - jauh sebelum bangsa ini masuk dalam era Monarki. Poly-Yahwisme telah ada sejak diperkenalkan atau memperkenalkan dirinya kepada Israel.

Dalam analisis pada Bab II, penulis telah menjelaskan mengenai konsep sidang ilahi Ugarit yang identik dengan Kanaan; yang juga dipakai oleh Israel semenjak era Patriak. Beberapa konsep sidang ilahi yang dikenal adalah $p h r$ 'ilm (perkumpulan para Allah), $M p h r t / p h r$ (Perkumpulan anak-anak El), bn 'ilm (anak-anak Allah), phr m'd (perkumpulan dalam sidang), dan $\mathrm{phr} \mathrm{kkbm}$ (perkumpulan bintang-bintang). Sidang ilahi ini dipimpin oleh kepala Panteon El dan Asherah sebagai Allah level pertama, disusul Ba'al, Yahweh di level kedua. Level ketiga dihuni oleh dewa-dewa yang ahli dalam bidang tertentu; seperti Khotar Wa Hasis, dan level keempat ditempati para dewa pembawa pesan (Handy, Mc. Gynn dan Smith). Konsep sidang ilahi ini terus bertahan di Israel sampai dengan era pasca Pembuangan, namun telah mengalami transformasi besar-besaran. Dengan arah monoteisme yang dimiliki Israel di mana Yahweh menjadi satu-satunya Allah Israel, maka anggota sidang ilahi dalam gambaran Ugarit dan Israel awal kehilangan identitasnya. Seluruh anggota sidang ini hanya menjalankan fungsi sebatas pahlawanpahlawan, pembawa pesan dan penengah (intermediator) semata. Dalam gambaran Ayub 1:6-12, 2:1-7 dan Zakaria 3:1-7, yang merupakan teks pasca Pembuangan, kita melihat perubahan besar yang terjadi tersebut. Pasal ini dengan jelas memberi informasi bahwa manusia fana yang benar bisa diundang ke dalam hadirat Allah dan berpartisipasi dalam kerajaanNya sebagai bagian dari anggota kerajaan Allah. Dalam teks Zakaria pasal 3 inilah imam Yosua menemukan dirinya berdiri di hadapan Allah dan anggota Sidang Ilahi lainnya yang duduk di sebelah kanan dan kiri Allah; bertindak sebagai penasehat yang nantinya menjalankan keputusannya. ${ }^{141}$ Dua figur juga hadir dalam sidang tersebut yaitu malaikat dan setan sang

${ }^{141}$ Ibid., Cross, "Canaanite Myth and Hebrew Epic, 187 
penuduh. Kedua-duanya merupakan anggota sidang ilahi. ${ }^{142}$ Jika kembali ke-masa pra-Pembuangan, maka kita menemukan konsep serupa dalam Mazmur 82:1-8. Dalam teks ini, nampaknya yang memimpin sidang adalah malak Yahweh dan bukan Yahweh sendiri. Yahweh terlihat semakin transenden dengan meninggalkan sidang dipimpin oleh malak Yahweh.

Dalam cerita Ayub, sosok setan tidak lagi sebatas penuduh seperti dalam Panteon Ugarit, melainkan ia memiliki tugas pengawasan atas Manusia di Bumi. Dalam kedua narasi ini, Yahweh memberikan kuasa untuk menguji Ayub. Dalam teks Ayub dan Zakaria ini kita juga melihat bahwa 'setan' adalah 'titel' atau epitet dan bukan 'nama diri.' Untuk itu, tidak ada satupun catatan Perjanjian Lama yang menempatkan figur ini berlawanan dengan Allah. Akan tetapi dalam materi pasca Pembuangan, setan menjadi sosok dan sumber dari kejahatan. Dalam catatan masyarakat Qumran, setan menjadi simbol dari roh kejahatan yang dipertentangkan dengan roh kebenaran. ${ }^{143}$ Teks-teks Apokrifa dan Pseudipigrafa menyebut setan dengan panggilan mastemah: musuh dan kejahatan. Bahkan dalam 2 Henokh 29:4-5, setan digambarkan dibuang dari surga dengan sejumlah malaikat karena memberontak kepada Allah. Dalam Ayub dan Zakaria setan adalah penjaga bumi sekaligus bagian dari sidang ilahi, maka dalam era pasca Pembuangan ia berkembang dalam personifikasi dan sumber kejahatan. ${ }^{144}$

Selanjutnya kita melihat malaikat yang dalam konsep sidang ilahi Ugarit sebatas pembawa pesan, maka pada era ini berubah dengan memiliki peran khusus atas Manusia dan kerajaan surgawi; mereka diperintahkan menjaga alam semesta dalam teks Jubille 2:2. Sosok ini menjadi mediator dalam 1 Henokh 99:3, anak-anak terang

${ }^{142}$ Ibid., Cross, "Canaanite Myth and Hebrew Epic, 187-188

${ }^{143}$ E. Theodore Mullen, Jr., The Divine Council In Canaanite And Early Hebrew Literature, (USA: Harvard Semitic Monographs, 1980), 276.

${ }^{144}$ Ibid., Mullen, Jr., The Divine Council In Canaanite, 276 
dalam catatan Qumran 1QM 13:10, dan roh kebenaran. Sekaligus kita melihat dalam era ini tidak lagi hadir ide Sidang Ilahi dan anggotaanggotanya, digantikan oleh Yahweh yang memerintah secara total melalui para malaikat yang diberi tugas. Menurut D.S. Russel, perubahan ini terjadi karena beberapa alasan: pertama, munculnya ide transendensi Allah, kedua, penciptaan malaikat diperlukan untuk menjembatani Allah dan Manusia, ketiga, keberadaan manusia dan dunia jahat, keempat, perbedaan roh: yang baik dan jahat. ${ }^{145}$ Munculnya fungsi khusus dari para malaikat dalam periode ini, otomatis menghilangkan model Sidang Ilahi yang disusun sedemikian rupa dengan fungsinya masing-masing. Malaikat berubah dari sekedar pembawa pesan, menjadi penjaga bumi dan Manusia; sekaligus mediator dengan Allah.

Persoalan pembuangan yang dialami Israel, sepertinya mendorong mereka membangun konsep baru dalam kehidupan etisnya. Mulai muncul ide mengenai "baik dan buruk" sebagai alat ukur untuk melangkah ke dalam restorasi bangsa. Yahweh adalah baik, sedangkan setan dan pengikutnya adalah jahat. Terjadi tarikmenarik kekuasaan atas manusia antara yang kekuatan baik dan jahat tersebut. Selain itu, kita juga menemukan bahwa Yahweh menjadi lebih transenden pada era ini dibandingkan sebelum pembuangan dengan sistem Panteon Kanaannya.

Inilah perkembangan keagamaan Israel; khususnya Yahweh dan El yang telah dipaparkan di atas, memperlihatkan hadirnya pluralisme ilah dan model kepercayaan monolatri dalam agama Israel, di mana Yahweh dan El termasuk di dalamnya. Sebelumnya kita telah melihat pluralisme El yang disembah oleh Patriak telah dipaparkan dalam Bab II disertasi ini, yang dilanjutkan dengan pluralisme Yahweh - dapat juga dikatakan sebagai poliYahwisme dalam Bab III. Dalam analisis pada kedua Bab tersebut,

145 D.S. Russel, The Method and Message of Jewish Apocalypse, (Hymns Ancient \& Modern Ltd; Revised ed. Edition 2012), 237 
penulis menemukan sosok Yahweh hadir dalam banyak bentuk dan makna - sekaligus Ia diketahui berasal dari beberapa lokasi berbeda di Dunia Timur Tengah Kuno. Untuk itu kita maklum ketika melihat keadaan keagamaan Israel saat itu - bahkan sampai pada era Monarki - di mana model religius Israel ternyata tidak berbeda dengan masyarakat Kanaan pada umumnya yang Monolatri atau Henoteis. Dan dalam Bab V ini, penulis telah membahas mengenai pluralitas penyembahan di Israel dan Yehuda; di mana El dan Yahweh memainkan peran siknifikan; baik di Kerjaan Utara maupun Selatan, bersama dengan ilah lain seperti Asherah dan Ba'al. Pada bagian akhir, penulis memperlihatkan bagaimana Yahweh tetap hadir dalam berita para nabi pasca Pembuangan untuk memberikan penghiburan dan kekuatan bagi Israel dalam pembuangan. Penulis juga memperlihatkan bagaimana konsep Sidang Ilahi telah berubah pada era Pembuangan. Malaikat berubah fungsi sebagai pengurus alam semesta dan mediator manusia. Status ini berubah drastis dari status sebelumnya yang hanya sekedar pembawa pesan dalam Sidang Ilahi Kanaan di mana El menjadi kepala Panteon. Setan yang dalam konteks Ayub dan Zakaria; terutama dalam konsep Panteon Kanaan sebatas sebagai epitet, pada era pasca Pembuangan menjadi Nama Diri. Setan dipersonifikasi dan menjadi sumber kejahatan; bahkan ia digambarkan menarik malaikat jatuh dari surga dalam Kitab Henokh. 


\section{BAB V}

\section{SIMPULAN}

El dan Yahweh adalah dua Allah utama Israel yang sering disebut sebagai ilah identik; sekaligus tidak identik dalam ranah tafsir dan teologi Perjanjian Lama. Dalam penulisan disertasi ini, penulis telah berusaha menganalisis dan memaparkan kedua Allah Israel tersebut; dimulai dari asal-usul mereka, kemunculannya dalam dunia Kanaan dan Israel, bagaimana mereka berkembang dan berinovasi, sampai dengan hasil akhir yang terlihat pada era pascaPembuangan.

Beragam metode penelitian dipergunakan untuk menelaah teks-teks yang berasal dari Dunia Timur Tengah Kuno; terutama teks Perjanjian Lama. Wellhaussen yang diikuti oleh Albright dan Fohrer, menetapkan sistem agama Israel berbeda dengan sistem agama Kanaan. Israel yang memiliki Allah Yahweh, di Kanaan berjumpa dengan orang Kanaan dan El, allah yang mereka sembah. Israel dalam suatu waktu tertentu digambarkan melakukan sinkretisme dengan agama Kanaan. Agama Israel menurut Albright dan Fohrer berevolusi dari satu level kepada level lainnya.

Penelitian kemudian yang diprakarsai oleh Albright, Cross, Albertz, Edelmann dan Smith, lebih menekankan pada proposisi agama Israel tidak berbeda dengan agama Kanaan. Alasan para ahli ini Israel dan sistem agamanya berasal dari matriks Kanaan itu sendiri. Metode developmentari yang mereka kembangkan semakin diperkuat melalui metode penelitian sosial yang dikembangkan oleh para sarjana biblika sosiologi seperti, Gottwald dan Durkheim. Menurut kelompok ini, sistem agama apapun di dunia tidak pernah terlepas dari kaidah-kaidah, tindakan-tindakan dan 
hubungan sosial masyarakat serta dengan wilayah di mana agama tersebut berkembang.

Kekayaan tafsir ini semakin terlihat ketika metode arkeologi yang selama ini dipandang sebagai 'alat bantu' penafsiran dalam model tafsir konservatif, mendapat ruang yang lebih luas untuk dipergunakan. Menurut William Dever, menafsir teks-teks kuno; termasuk teks Perjanjian Lama hanya berdasarkan sumber dari teks itu sendiri (soft data), tanpa memperhatikan sumber ekstra-biblika (hard data), tidak mampu memberikan jawaban memuaskan mengenai apa yang sesungguhnya terjadi yang digambarkan dalam teks.

Bentuk penelitian multi metode yang dikembangkan para ahli teks-teks kuno Dunia Timur Tengah, pada akhirnya memberikan jawab terhadap banyak pertanyaan yang selama ini tidak terjawab. Melalui bukti-bukti arkeologi yang ditemukan di Ugarit, kita dapat mengetahui bahwa Kanaan dan Israel di kemudian hari memiliki sistem Panteon dalam sistem agama mereka. Panteon yang dipimpin oleh El sebagai dewa tertinggi, memiliki kesamaan struktur baik di Kanaan maupun di Israel. Panteon digambarkan memiliki Sidang Ilahi yang dipimpin El dan Anat atau Asherah. Pada level kedua, terdapat dewa-dewa yang melakukan fungsi eksekutif seperti Ba'al, Mot, Yamn dan Yahweh. Level ketiga dihuni oleh dewa-dewa yang ahli dalam bidang keahlian tertentu seperti Khotar wa Hazis yang membangun istana Ba'al. Selanjutanya para dewa yang berfungsi sebagai pembawa pesan, menempati urutan terakhir dari sistem Panteon ini.

Sistem Panteon Ugarit ini memiliki kesamaan struktur dengan sistem Panteon Israel. Dalam sistem Panteon Israel, mulamula El digambarkan sebagai Allah tertinggi dan Yahweh menduduki posisi kedua bersama Ba'al dan Anat. El sebagai Allah tertinggi dikenal oleh para Patriak Israel dengan sebutan "Allah Bapaku dan Allah bapamu." Selain itu, para Patria juga memanggil Allah mereka 
dengan sebutan Elohe Abraham, Elohe Ishak, Elohe Yakub, Elohe nahor dan El Elohoe Yizrael.

Para Patriak diketahui mengenal tipe nama El lainnya yang dihubungkan dengan tempat tertentu, seperti" El Olam yang dapat berarti Allah yang kekal, atau Allah dari Olam. Mayoritas sarjana modern setuju apabila El Olam diterjemahkan sebagai "Allah perjanjian dan Allah Masa Depan." Selain El Olam, ada El Roi dari Berlahai Roi. El Roi ditemukan dalam naskah Kejadian 14 dalam narasi Hagar ketika ia bertemu dengan malaikat. El Lainnya yang sering ditemukan dalam konteks Patriak adalah El Bethel yang pertama-kali bertemu dengan Abraham, disusul Yakub. El Bethel memiliki pengertian khusus sebagai Allah yang dari Bethel dan Allah Perjanjian. Dalam hal ini perjanjian yang pernah terjadi dengan Abraham dan Yakub. Selanjutnya ada sosok yang dikenal sebagai El Elyon yang merupakan kepala Panteon di Kanaan; khususnya di kota Yerusalem; merupakan Allah yang sering diidentikkan dengan El Shadday dan Yahweh. El Elyon kelihatannya tidak saja memiliki arti Allah maha tinggi, melainkan ia juga dapat disebut sebagai Allah pencipta langit dan bumi. El Elyon diduga merupakan sesembahan suku Abraham. Pada akhirnya kita melihat nama El Shadday yang sering ditemukan dalam teks-teks Patriak. Nama El Shadday umumnya diterjemahkan dengan 'Allah Maha-Kuasa,' yang merupakan sesembahan kelompok Yakub. Akan tetapi, akhir-akhir ini para sarjana Perjanjian Lama sering menterjemahkan Allah ini dalam konteks feminin dengan arti Allah kesuburan, dengan alasan kata dasar shadi yang dipergunakan memiliki arti buah dada. Buah dada identik dengan pemeliharaan, proteksi dan berkat.

Dari nama-nama El yang digambarkan di atas, maka El dapat berupa kata generik dari suatu 'ilah' atau epitet dari suatu nama allah dan allah-allah, atau dapat juga dikenakan kepada tempat tertentu, seperti El Roi di Berlahai Roi dan El Olam di Bersyeba. Namun yang terutama dari Allah El ini adalah, mereka sangat dikenal 
oleh para Patriak sekaligus menjadi ilah sesembahan mereka yang di kemudian hari di identikkan dengan Yahweh.

Catatan Perjanjian Lama menyebutkan Israel keluar dari Mesir dipimpin oleh Allah yang disebut Yahweh. Yahweh yang ditemukan atau bertemu dengan Musa di Sinai ini ternyata cukup sulit ditelusuri asal kata dan arti. Yahweh dapat berarti ia yang menyebabkan, ia yang membawa keberadaan, ia yang melewatkan, atau ia yang menciptakan. Nama ini dapat juga berarti 'aku akan berserta engkau', atau 'akulah dia yang menjadikan segala sesuatu.' Terjemahan 'akulah dia yang menjadikan segala sesuatu' menurut penulis terjemahan yang paling mendekati benar.

Kesulitan arti nama Yahweh berlanjut pada kesulitan menentukan asal-mula Allah ini. Ada beberapa teori yang dikembangkan dan diterima umum mengenai asal-mula Yahweh. Teori Keni merupakan teori yang paling dikenal dan paling banyak dipergunakan para penafsir nama Yahweh. Dalam teori ini, Yahweh digambarkan berasal dari Midian; wilayah keturunan Keni (Kain). Yitro yang merupakan penyembah Yahweh memperkenalkan Allah ini kepada Musa saat Musa berada di Midian.

Selain Yahweh yang berasal dari Midian, teks Ulangan 32 dan Hakim-Hakim 5, memaparkan Yahweh yang datang dari Selatan; Edom atau Paran. Yahweh digambarkan berderap dari selatan untuk membantu Israel yang sedang berperang di Kanaan. Tradisi Yahweh sebagai pahlawan perang dari selatan ini tergambar dengan jelas dalam catatan Hakim-Hakim pasal 5 - dalam konteks Hakim Debora. Apabila melihat ke belakang, kita menemukan Edom yang merupakan saudara Israel - yang dipercaya sebagai suku penyembah Yahweh, maka teori ini pada telah mendapat landasan berpijak. Apalagi jika memperhatikan hampir tidak ada cercaan Israel kepada saudaranya Edom, maka dipastikan Allah yang disembah Edom saat itu adalah Yahweh; dan Yahweh yang sama kemudian diperkenalkan kepada Israel. Itulah sebabnya teks Ulangan 32, 
Hakim-Hakim 5 dan Habakuk 3, dengan yakin menyatakan Yahweh yang mereka sembah berasal dari selatan.

Selain informasi mengenai Yahweh yang berasal dari Midian, Edom dan Sinai, beberapa teks Perjanjian Lama juga memberikan informasi mengenai Yahweh yang datang dari gunung Bashan (Maz. 68), Yahweh dari Paran dalam Habakuk 3:3. Dalam Habakuk 3, narrator menempatkan Yahweh berdiri sejajar dengan $\mathrm{Ba}$ 'al, atau menyatakan bahwa Yahweh adalah Ba'al yang mengalahkan Yam dalam upaya memberikan penghiburan kepada Israel yang menetap di wilayah Trans-Jordan yang jauh dari saudarasaudaranya, sekaligus mereka rentan menghadapi serangan dari bangsa-bangsa sekitarnya. Identifikasi Yahweh dengan $\mathrm{Ba}$ 'al dalam teks ini memberikan petunjuk Ba'al merupakan Allah yang juga mendapat tempat luas di maysrakat Trans-Jordan.

Penemuan Inskripsi di Kuntillet Ajrud dan Khirbet el Qom yang memunculkan nama Yahweh bersanding dengan Asherah, menciptakan warna baru dalam penelitan teks-teks Dunia Timur Tengah Kuno. Penemuan inskripsi Kuntilet Ajrud ini kemudian mendapat klarifikasi dari penemuan arkeologi di Khirbet-el-Qom (Makeda dalam kitab Ibrani), yang berlokasi sekitar $13 \mathrm{Km}$ sebelah Barat Hebron pada tahun 1967 oleh William Dever.

Penemuan ini membuka babak baru dalam penelitian teks-teks kuno Mesopotamia. Yahweh yang digambarkan berasal dari Teman dan Shomron, selama ini dipahami sebagai Allah yang berdiri sendiri, berbeda dengan Allah Kanaan, atau sering digambarkan mengecam para dewa dan dewi Kanaan, dalam inskripsi ini digambarkan berpasangan dengan Asherah; dewi yang notabene sering dikecam. Dengan gambaran yang muncul ini dalam kedua inskripsi yang menggambarkan Yahweh berpasangan dengan Asherah, maka, sangat sulit kita menetapkan Israel sebagai penganut paham monoteisme; paham yang notabene tidak dikenal masyarakat Israel kuno. 
Teks Perjanjian Lama memberikan gambaran dunia Politeistik Israel - dunia serupa dengan orang Kanaan disekitar mereka. Israel memiliki banyak varian Allah untuk disembah; di mana El dan Yahweh termasuk di dalamnya. Bukan saja multi Allah, multi-El dan multi-Yahweh merupakan bagian intrinsik dari sistem agama Israel. Gambaran Politeistik, Henoteis dan Monolatri, merupakan gambaran umum dalam agama Israel. Monoteisme bukan pilihan Israel saat itu. Monoteisme seperti yang kita ketahui hanya hadir setelah Israel kembali dari pembuangan. Termasuk kepercayaan terhadap El dan Yahweh yang beragam, menguatkan argument Israel sebagai penganut monolatri.

Teks Keluaran pasal 3 dan 6 memberikan ide bahwa Yahweh yang dikenal Musa merupakan Yahweh yang pernah menyatakan dirinya kepada Patriak, namun saat itu, ia - Yahweh belum menyatakan dirinya. Mengikuti alur teks ini, kita dapat simpulkan bahwa El dan Yahweh merupakan ilah yang identik atau serupa. Para sarjana Perjanjian Lama terbagi dua golongan untuk menentukan arti teks ini. Golongan pertama yang didukung Welhaussen, Alt dan Heisser, menetapkan Yahweh dan El dalam Keluaran pasal 3 dan 6 di atas sebagai ilah identik. Sebaliknya, golongan kedua yang didukung oleh Smith, Albertz, Edelmann, Handy dan Parker, percaya bahwa El dan Yahweh dalam kedua teks Keluaran tersebut merupakan ilah berbeda.

Selain teks Keluaran 3 dan 6, polemik apakah El dan Yahweh ilah identik atau berbeda, muncul dalam teks Ulangan 32 dan Mazmur 82. Teks-teks tersebut menggambarkan para anggota sidang ilahi yang sedang bersidang; di mana El dan Yahweh hadir. Kelompok sarjana pendukung El dan Yahweh ilah identik; seperti Heisser, berasumsi Yahweh sebagai kepala Panteon dalam sidang tersebut. Sedangkan Smith dan Parker, melihat sidang ilahi tersebut dipimpin oleh El; Yahweh adalah salah satu ilah yang hadir dalam 
sidang itu. Yahweh bukan sebagai ilah utama; melainkan El yang menjadi ilah utama.

Berdasarkan analisis teks-teks tersebut, penulis menyimpulkan El dan Yahweh merupakan dua ilah berbeda yang beroperasi dalam periode yang berbeda - termasuk lokasi berbeda. Hal ini tidak menafikan bahwa mereka pernah beroperasi pada waktu dan lokasi yang sama, namun yang ditekankan penulis adalah: keduanya tidak identik. El merupakan Allah sesembahan para Patriak dan masyarakat Timur Tengah Kuno yang terekam dalam dokumen Ugarit dan Pentatuk. Para Patriak mengenal El dengan beragam Nama Diri dan epitet; yang umumnya tercatat dalam kitab Kejadian. Sedangkan Yahweh, sosok ini merupakan Allah yang memperkenalkan dirinya kepada Musa, dan Musa memperkenalkan Yahweh kepada Israel dalam proses keluaran dari Mesir. Walaupun Keluaran pasal 3 dan 6 menggambarkan seolah-olah Yahweh telah dikenal oleh Patriak, namun kedua teks tersebut ternyata tidak memiliki informasi lengkap untuk menguatkan argumentasinya.

Dalam perkembangannya di Israel, Yahweh dan El memainkan peran siknifikan di Israel dan Yehuda. Di Israel, Yahweh menjadi Allah utama selain El yang disembah di kerajaan Saul. Raja Saul membuat Yahweh menjadi Allah nasional yang identik dengan peperangan. Yahweh dalam pemahaman Saul adalah Allah yang memberikan kemenangan kepada Israel. Selain itu, sosok El terbukti menjadi Allah utama Israel sampai era monarki ini. Ia disembah bersama-sama dengan Asherah. El memainkan peran penting di Israel, yang kemudian mendapat kecaman dari beberapa nabi Israel dengan alasan menyesatkan Israel dari penyembahan terhadap Yahweh. Hosea mengecam El sedemikian rupa - sekaligus menciptakan ironi dirinya sebagai pengagum El dengan memberikan anak-anaknya nama yang menggunakan teoforik EL. El juga mendapat tantangan dari Elia dan Elisha. Akan tetapi, Ba'al yang menjadi korban dari idealisme Yahweh kedua nabi tersebut. Dalam 
waktu yang panjang di Israel, El masih menjadi Allah utama bersamasama dengan Yahweh.

Sedangkan di selatan -Yehuda, penyembahan terhadap Yahweh diketahui memainkan peran penting dalam masyarakat Israel. Yahweh menjadi Allah utama Israel; terutama ketika Daud menguasai Yerusalem dan menjadikan Yerusalem sebagai pusat ibadah terhadap Yahweh. Namun demikian, tidak berarti penyembahan terhadap El tidak terlihat di Yerusalem. El Elyon yang merupakan ilah kota Yerusalem Yahweh diperkenalkan masih memainkan peran sebagai Allah utama saat itu. Walaupun ada informasi El Elyon diidentikkan dengan Yahweh, akan tetapi proses identifikasi ini tidak pernah menghapuskan kehadiran El Elyon sebagai Allah berbeda dengan Yahweh di Yerusalem. Di hari kemudian Elyon disetarakan atau melebur dalam diri Yahweh, dipandang sebagai hasil sentralisasi ibadah yang terus-menerus dilakukan oleh Daud dan kaum reformator Yehuda dalam upayanya menetapkan Yerusalem sebagai pusat Yahweh.

Dalam periode monarki, Yahweh dan El terus menjadi Allah utama di kedua kerajaan tersebut; terutama El di Utara dan Yahweh di Selatan. upaya sentralisasi Yahweh yang terus menerus dilakukan, pada akhirnya mulai berhasil melemahkan penyembahan terhadap El. El perlahan-lahan mulai kehilangan pamor dan penyembahnya, sedangkan Yahweh semakin dikenal dan bertambah pengikutnya. Hal ini semakin diperkuat dengan berbagai bentuk reformasi yang pada umumnya terjadi di Yehuda yang berupaya menetapkan Yahweh sebagai Allah utama Israel. Pada akhirnya penyembahan terhadap El menghilang dalam agama Israel. Yahweh kemudian diketahui banyak mengambil epitet yang biasa dikenakan kepada El, yang juga dikenakan kepada Yahweh. Pangadopsian Epitet ini diperlukan untuk melakukan kesetaraan antara El dan Yahweh di Israel. Tujuan penyetaraan ini untuk mengakomodir kepentingan orang Israel yang masih mendukung El, sekaligus 
menyatakan secara teologis bahwa El dan Yahweh merupakan ilah identik.

Penyembahan terhadap Yahweh pada era Pembuangan dan pasca Pembuangan nampaknya terus berlanjut. El sudah tidak dikenal lagi oleh orang Israel, konsep Sidang Ilahi sudah terhapus dari sistem agama Israel pasca Pembuangan. Yahweh digambarkan muncul dalam banyak tempat; bahkan ia muncul di luar Israel; dalam kultus di mana orang Israel hadir dan menyembahnya. Israel yang tidak mengenal bentuk Sidang Ilahi seperti era sebelum pembuangan, menciptakan warna baru dalam berteologi. Figur setan yang selama ini dikenal hanya sebatas titel atau epitet dalam masyarakat Israel sebelum pembuangan, pada era ini menjadi Nama Diri. Setan mengalami personifikasi dan identik dengan kegelapan dan kejahatan. Malaikat yang dalam konsep Sidang Ilahi Kanaan sebatas sebagai pembawa pesan, saat ini menjadi pengantara Manusia dengan Tuhan, sekaligus sebagai penjaga alam semesta ini. Pada akhirnya konsep Yahweh sebagai Allah konkret yang dapat dirasa dan diraba di era Israel kuno, berubah menjadi transenden.

Yahweh masih terus menjadi Allah Israel, El kehilangan nama, pamor dan kekuatannya. Banyak epitet El diadopsi oleh Yahweh. Kedua Allah ini pada akhirnya dapat ditetapkan sebagai dua ilah berbeda, berfusi dan pada akhirnya hanya Yahweh yang muncul dengan tetap membawa epitet El dalam dirinya. 


\section{Kepustakaan}

Ahlstrom. G. W. Aspect of Syncretism in Israelite Religion, Horae Soedarblomianae V, Lund, 1963

."King Jehu--A Prophet's Mistake." Dalam Arthur Merrill and Thomas Overholt (eds). Scripture in History and Theology. Pittsburgh, Pickwick: Theological Monograph Series 17, 1977.

Albertz. Rainer. A History of Israelite Religion. Westminster: John Knox Press, 1992.

Albright. William. F. "The Names Shaddai and Abram." Journal of Biblical Literature 54 (1935). 173-204.

. "The Israelite Conquest of Canaan in the Light of Archaeology.” BASOR 74 (1939). 1-23

. Yahweh and the Gods of Canaan: A Historical Analysis of Two Contrasting Faiths. London: Athlone Press, 1968.

Alt. Albrecht. Essay on Old Testament History and Religion. Oxford: Basic Blackwell, 1966.

. Essay on Old Testament History and Religion. Sheffield Academic Press, 1989.

Anderson. A. A. The Book Of Psalms: Psalm 1-72, The New Century Bible Commentary, ed. Ronald E. Clements, 2 Vols, Grand Rapids: Eerdsman, 1979. 
Beck. Pirhiya. "The Drawings from Horvat Teiman, (Kuntillet Ajrud)," Journal of the Institute of Archaeology of Tel Aviv University 9 (1982). 3-68.

Bellah, Robert, dan Tipton, Steven, M. The Robert Bellah Reader. Durham and London: Duke University Press, 2006.

Biale. David. "The God With Breasts: El Shadday in the Bible." HR 20. Number 3 (1982). 249-250.

Binger. Tilde. "Asherah in Israel" in Scandinavian Journal of the $O T$ 9/ 11 (1995). 3-18.

Boesak. Willa. "Exegesis and Proclamation, Psalm 82: God AMids the Gods." Journal of Theology for Southern Africa, No. 64 (1988). 64-68.

Brownlee. W H. 'The Ineffable Name of God." BASOR 226 (1977). $39-46$.

Buber. Martin. Moses. Oxford, London: East \& West Library, 1944.

Cassuto. Umberto. "A Commentary on the Book of Exodus." (trans). Israel Abraham. Jerusalem: Magnes, 1967.

Child. Brevard. S. Exodus: A Commenteary. London: SCM Press, 1974.

Clements. R E. Exodus. Cambridge: Cambridge University Press, 1972.

Clifford. Richard. J. The Cosmic Mountain in Canaan and the Old Testament. HSM 4. Cambridge, MA: Harvard University Press. 1972. 
Cohen. Jeffrey. M. "How God Introduced Himself to the Patriarch." $J B Q 37$, No. 2 (2009). 119-120.

Cook. Stanley. A. The Religion of Ancient Palestine in The Light Of Archaelogy. London: Oxford University Press, 1930.

Cook. Stephen. L. The Roots of Biblical Yahwism. Boston: Leiden Brill, 2004.

Cross. Frank. Moor (ed). "La 'êl." Botterweck et al vol 1 (19742001). 242-261

. Canaanite Myth and Hebrew Epic: Essay in the History of the Religion of Israel. Massachussets: Harvard University Press, 1973.

Curtis. A. Cities of the Biblical World: Ugarit Ras Shamra. Cambridge: Luttenworth, 1985.

Dearman. J. A. Edomite Religion: A Survey and an Examination of Some Recent Contributions. Dalam D.V. Edelmann (ed), You Shall Not Abhor an Edomite for He is Your Brother. Atlanta: Scholar Press, 1995.

Dennis. Pardee. “Ritual and Cult.” SBL 10 (2002). 253.

Dever. William. G. "Asherah, Consort of Yahweh? New Evidence from Kuntillet 'Ajrûd.” BASOR Vol. 255 (1984). 21-37. ..Recent Archaeological Discoveries and Biblikal Research. Seattle: University of Washington Press, 1990.

. "Archaeology and the Ancient Israelite Cult: How the Kh. el-Qôm and Kuntillet 'Ajrûd 'Asherah' Texts Have Changed the Picture." Eretz Israel, Vol. 26 (1999). 210. 
. What The Biblikal Writers Know And When Did They Know It? Grand Rapids, Michigan, William B. Werdsmans Publisihng Company, 2001.

- "Recent Archaeological Confirmation of the Cult of Asherah in Ancient Israel," Hebrew Studies, Vol. 23 (1982). 37-43.

. "Asherah, Consort of Yahweh? New Evidence from Kuntillet Ajrûd," BASOR Vol. 255 (1984). 21-39.

Driver. G. R. Canaanite Myths and Legends. Edinburgh: T. \& T. Clark, 1956.

Driver. G R. "The Original form of the name Yahweh: Evidence And Conclusions." ZAW 5 (1928). 500-502.

Edelmann. Diana. V. the Rise of the Israelite State Under Saul Chicago: University of Chicago, 1986.

Eichrodt. W. Religion of Israel. Bern-Munich: Hebrew Verlag. 1953.

Evans. G. "Ancient Mesopotamian Assemblies: An Addendum," JAOS 78 (1958). 114.

Fohrer. Georg. History of Israelite Religion. Nashville: Abingdon Press, 1972.

Freedman. D.N. "The Name of the God of Moses." JBL 79 (1960). 151-156.

(1987). 241-249.

"Yahweh of Samaria and his Asherah," BAR Vol. 50

Garr. Randall. In His Own Image and Likeness. Humanity, Divinity, and Monotheism. Leiden: Brill, 2003. 
. "The Grammar and Interpretation of Exodus 6:3." JBL 111 (1992). 388.

Gelb. L. J. Old Akkadian Writing and Grammar. Chicago: The University of Michigan, 1961.

Ginn. Mc. The Divine Council and Israelite Monotheism. Hamilton, Ontaria: Mc. Master Universit, 2005.

Goitein. S. D. "YHWH The Passionate: The Monotheistic Meaning And Origin Of The Name YHWH." VT 6 (1956). 1-9.

Gottwald. Norman. K. The Tribes of Yahweh: A Sociology of the Religion of Liberated Israel, 1.250-1.050 BCE. London: SCM Press Ltd, 1980.

H. Lewy. "Mari.” ed. Buttrick. Vol 3 (1962). 264-266.

Habel. "Yahweh Maker of Heaven and Earth: A Study in Tradition Criticism.” JBL. 91 (1972). 321-337.

Hadley. Judith. M. Yahweh's Asherah in Light of Recent Discovene. England: Ph. D. dissertation at University of Cambridge, 1989.

- The Cult of Asherah in Ancient Israel and Judah: Evidence for a Hebrew Goddess. Cambridge: Cambridge University Press, 2000.

Halpern. Baruch. "Kenites.” Dalam. David Noel Freedman (ed). The Anchor Bible Dictionar.y New York: Doubleday, 1992.

Handy. Lowell. K. "The Appearance of Pantheon in Judah.” Dalam Diana Vikander Edelman, (ed) The Triumph of Elohim. 
Grand Rapids, Michigan: William B. Eerdsmans Publishing Company, 1996.

Heiser. Michael. S.The Divine Council in Late Canonical and Non Canonical Second Temple Jewish Literature. Madison: University of Wisconsin, 2008.

Hess. Richard. S. Israelite Religion: An Archaelogical and Biblikal Surveys. Grand Rapids: Michigan, 2007.

Jacobsen. T. "Primitive Democracy in Ancient Mesopotamia." JNES 2 (1943). 159-172

Joosten. Jan. "A note on the text of Deuteronomy xxxii 8." VT 57 (2007). 548-555.

KAI. Terj. J. Blau. Dalam Short Philological Notes on the Inscription of Mesa, Maarau (1979-1980). 181:14-18

Kauffman. Yehezkiel. The Religon of Israel: From it's Beginning to the Babylonian Exile. London: Allen and Unwin, 1961.

Kingsbury. John. E.C. "The Prophets and the Council of Yahweh." JBL 83 (1964). 279-286.

Kirk. G. S. Myth: Meaning and Functions in Ancient and Other Culture. Cambridge: University Press, 1970.

Kohlenberger. III John. R. The Interlinear NIV Hebrew-English Old Testament. Grand Rapids: Zondervan Publishing, 1987.

L 'Heureux C. E. Rank Among the Canaanites Gods: EL, Ba' 'al, and the Repha 'im. Montana: Scholar Press, 1979.

Lemaire. Andre. "New Aramaic Ostraca from Idumea and Their Historical Interpretation." Dalam Oded Lipschits and 
Manfred Oeming (eds.). Judah and the Judeans in the Persian Period. Winona Lake, IN: Eisenbrauns, 2006. ."Who or What Was Yahweh's Asherah?” BAR 10 (1984). $42-47$.

Lohfink. Norbert. Theology of the Pentateuch, trans. Linda Maloney. Edinburgh, T \& T Clark, 1994.

MacLaurin. E. C. B. "YHWH: the origin of the Tetragrammaton." VT 12 (1962). 439-463.

Magonet. Jonathan. "The Bush that Never Burnt: Narrative Techniques in Exodus 3 and 6." The Heythrop Journal 16 (1975). 304-311.

Martin. W. J. Stylistic Criteria and te Analysis of the Pantateuch. London: Tyndale, 2003.

Mathews. Victor. H. Social World of Ancient Israel. Massachusets: Hendricksons Publisher Inch, 2005.

May. H. G. "The Patriarchal Idea of God." JBL. 60 (1941). 113-128.

Mendenhall. G. "The Hebrew Qonquest of Palestine." BA XXV/3 (1962). 66-87.

Menttinger T.N.D., Yahweh Zebaoth, DDD. Boston: Brill Leiden, 1999. . In Search of God: The Meaning and the Message of the Everlasting Names, trans. By F.H, Cryer. Philadelphia: Fortress Press, 1987. 
Miller. P.D. "Israelite Religion” Dalam D.A. Knight and G.M Tucker. (eds). The Hebrew Bible and its Modern Interpreters. Philadelphia: Fortress; Decatur, GA: Scholars, 1985.

. The Divine Warrior. Harvard: Harvard University

Press, 1963.

. The Religion of Ancient Israel. Lousville: Westminster John Knox Press, 2000

Moor. Johannes. De C. The Rise of Yahwism: The Roots of Israelite Monotheism. Belgium: Leuven University Press, 1990.

Mowinckel. S. “The Name of the God of Moses.” HUCA 32 (1961). 121-133.

Mullen. E. Theodore. The Divine Council in Canaanite and Early Hebrew Literatur. HSM 24; Chico, CA: Scholars, 1980.

Muraoka. T. Emphatic Words and Structures in Biblical Hebrew. Jerusalem: Magnes, 1985.

Natan. Mac. Donald. Dissertation: One God or one Lord?: Deuteronomy and the Meaning of Monotheism, Mohr Siebech. Tubingen: Germany, 2012.

Naveh. Joseph. “Graffiti and Dedications.” BASOR 235 (1979). 27-30.

Negef, dan S A, Gibson, Arcahelogical Encyclopedia of the Holy Land. Lodon: Continum, 2001.

Niehr. Herbert. The Rise of YHWH in Judahite and Israelite Religion: Methodological and Religio-Historical Aspects, Trans. and ed. Diana Vikander Edelman. Kampen: Kok Pharos Publishing House, 1996. 
Nikiprowetsky. V. 'Ethical Monotheism', Daedalus 104 (1975). 2

Noth. Marthin. Exodus Trans. J.S. Bowden, OTL London: SCM, 1962.

Oldenburg. Ulf The Conflict Between El and Ba'al in Canaanite Religion. Leiden:E.J. Brill, 1969.

Pardee. D. "Ugaritic Science." Dalam Vand der Toorn. (ed). JSTOR 320 (2000). 49-86

. "Ritual and Cult." SBL 10 (2002). 299

Parker. Simon. B. "The Beginning of the Reign of God-Psalm 82 as Myth and Liturgy." Revue Biblique 102 (1995). 533-534.

Peritz. Ismar. J. Old Testament History. New York: The Abingdon Press, 1923.

Philip. Pace. J. "The Deity Bethel and the Old Testament." JAOS 59 (1939). 87-88.

Pirhiya. Beck. "The Drawings from Horvat Teiman (Kuntillet Ajrud)." Tel Aviv (1982). 96-101.

Pitard. W.T. An Historical Overview of Pastoral Nomadism in the Euphrates Valley.Rotterdam: Balkema, 1989.

Porten. Bezalel. Archives from Elephantine: The Life of an Ancient Jewish Military Colon.y Berkeley: University of California Press, 1968.

Pritchard. James. B. Ancient Near Eastern Text Relating to the Old Testament. Princeton, New Jersey: Princeton University Press, 1969. 
Richard. J. Clifford, The Cosmic Mountain in Canaan and the Old Testament. (Cambridge, MA: Harvard University Press, 1972.

Rose. M. "Yahweh in Israel-Qaus in Edom.” JSOT 4 (1977). 28-34.

Rosenberg. Stephen G. "The Jewish Temple at Elephantine." NEA 67:1 (2004). 4-13

Ross. J.P. Jahweh Sebaot in Samuel and Psalm. VT 17 (1967). 76-92

Russel. D.S. The Method and Message of Jewish Apocalypse.Philadelphia: Westminster, 2012.

Sanders. Paul. The Provenance of Deuteronomy 32. Oudtestamentische Studien 37. Leiden: E. J. Brill, 1996.

Sarna. Nahum. The JPS Torah Commentary. Philadephia: The Jewish Publication Society, 1991.

Smith. Mark. S. The Early History of God. Harper \& Row, San Fransisco, 2002.

The Memoirs of God: History, Memory, and the Experience of the Divine in Ancient Israel. Minneapolis: Fortress Press, 2004.

. The Origin of Biblical Monotheism: Israel's Polytheistic Background and the Ugaritic Texts. New York: Oxford University Press, 2001.

Smith. Morton. 'On the Shape of God and the Humanity of Gentiles', in Religions in Antiquity. Leiden: Brill, 1968. 
Stern, Ephraim, dan Magen, Yitzhak, "Archaeological Evidence for the First Stage of the Samaritan Temple on Mount Gerizim.” IEJ 52 (2002). 49-57.

Tassker. D. Ancient Near Eastern Literature and the Hebrew Scriptures About the Fatherhood of God. New York: Peter Lang. 2004.

Theodore. Mullen. E. Jr. The Divine Council In Canaanite And Early Hebrew Literature. USA: Harvard Semitic Monographs, 1980.

Thomson. Thomas. L. "How Yahweh Became God: Exodus 3 and 6 and the Heart of the Penteuch." JSOT, 68 (1995). 57-74.

Tigay. Jeffrey. H. The Jewish Publication Society Torah Commentary: Deuteronomy: The Traditional Hebrew Text with the New JPS Translation. Philadelphia: Jewish Publication Society, 1996.

Toorn. Van der. K. 'Yahweh' Dictionary of Deities and Demons in the Bible. 2nd ed. Eds. Toorn, K. van der, Bob Becking, Pieter W. van der Horst. Leiden: Brill. 1999

Tsevat. M. "Studies in the Book of Samuel." HUCA 36 (1966). 49-58.

Vaux. De. Roland. "The Revelation of the Divine name YHWH." In Proclamation and Presence: Old Testament Essays in Honor of Gwynne Henton Davies, edited by John I. Durham and J. Roy Porter. London: SCM Press. 1970.

Vorländer. Hermann. 'Aspects of Popular Religion In The Old Testament', trans. Graham Harrison. Dalam Norbert Greinacher and Norbert Mette (eds). Concilium 186. Popular Religion. Edinburgh, T \& T Clark, 1986. 
Vriesen. Th. The Religion of Ancient Israel. Philadelphia: The Westminster Press, 1967.

Walker. Norman. "The Tetragrammaton, Its Origin, Meaning and Interpretation.” ZAW LXX (1958). 262-265.

Weippert. M. The Settlement of the Israelites Tribes in Palestine. London: SCM Press, 1971.

Wellhausen. J. Prolegomena to the History of Israel, trans. J.S. Black and A. Mazies. Edinburgh: A. \& C, 1885.

Wenham. Gordon . J. The Religion of the Patriarchs. Leicester: IVP, 1980.

Wimmer. Joseph F. "Tradition Reinterpreted in Ex 6, 2-7:7." Augustinianum 7 (1967). 410-416.

Wyat N., 1976, The relationship of Yahweh and El: a study of two cults and their related mythology. $\mathrm{PhD}$ thesis.University of Glasgow

Ze'ev, Meshel, dan Meyers, Carol. "The Name of God in the Wilderness of Zin," BAR. Vol. 39 (1976). 6-10. 